INSTITUTO DE PESQUISAS ENERGÉTICAS E NUCLEARES AUTARQUIA ASSOCIADA À UNIVERSIDADE DE SÃO PAULO

SÍNTESE E CARACTERIZAÇÃO DE PROLACTINA DE CAMUNDONGO (mPRL) E DE SEU ANÁLOGO (S177D-mPRL)

MIRIAM FUSSAE SUZUKI

Tese apresentada como parte dos requisitos para a obtenção do Grau de Doutor em Ciências na área de Tecnologia Nuclear - Aplicações

Orientador:

Prof. Dr. Carlos Roberto Jorge Soares

São Paulo 
If people never did silly things, nothing intelligent would ever get done. Ludwig Wittgenstein, filósofo austríaco (1889 - 1951) 
Dedicado ao meu pai - Sadao Suzuki (1935-2009), que sempre sonhou com o impossível. 
Agradecimentos

À orientação do Prof. Dr. Carlos que sempre teve uma palavra de incentivo e otimismo frente às inúmeras dificuldades desta jornada breve de descobertas e desafios.

Aos colegas pesquisadores do grupo de hormônios - Dr. Paolo Bartolini, Dra. Maria Teresa Carvalho P. Ribela, Dra. Cibele Nunes Peroni, Dra. Kayo Okazaki, Dr. João Ezequiel de Oliveira, que me ajudaram a caminhar e desbravar essa área da ciência.

Aos alunos de iniciação científica e pós-graduação - Fernanda dos Santos Arthuso, Taís Oliveira, Nélio de Jesus Oliveira, Herbert Rodrigues Goulart, Renata Damiani, Cláudia Regina Cecchi, Eliza Higuti, Beatriz Elane Almeida, Susana Heller, Cristiane Carvalho Moreira, Marcos Vinícius Capone, Maurício Jensen, Geyza Spigoti, que navegaram neste mesmo barco, dividindo as angústias e alegrias, em busca de resultados para novas publicações e congressos.

Aos colegas pesquisadores do Centro de Biotecnologia - Dra. Nanci do Nascimento, Dra. Olga Zazuco Higa, Dra. Lígia Ely Morganti Ferreira Dias, Dra. Regina Affonso, Dr. Patrick Jack Spencer, Dra. Maria Helena Bellini, Dra. Maria Aparecida P. Camillo, pelo apoio e incentivo.

Aos amigos do Centro de Biotecnologia - Janaína, Rosa, Karina, Rodrigo, Vicente, Natália, Laura, Tamara, Daniela pelos momentos de descontração e colaboração.

Ao apoio do pessoal técnico e administrativo - Rute, Arlete, Junqueira, José Maria, Rosângela, Neide, Calixto, Cícero, Genivalda, Longino, Eduardo, Dirce que ajudaram na burocracia e fizeram do dia-a-dia do laboratório mais agradável.

Ao pessoal da limpeza, Edna, Néia, Beth, Sandra, que ajudaram a manter o laboratório limpo e organizado.

Aos colegas do IPEN - Ana Claudia, Edson, Cibele, Sabrina, Luciana, Laura, Zé, Malvina, Gerulis, Renata, Priscilla, Adriana, Demerval, Elaine, Mauro, Alessandro, Sueli, pela amizade.

Aos colegas do Centro do Genoma Humano - IBUSP - Maria Denise Fernandes Carvalho, Mariane Secco, Eder Zucconi, Natássia Vieira, Carlos Roberto Bueno Júnior, Marcos Valadares, pela colaboração.

Aos colegas do Instituto Butantan - Dra. Eliana Nakano, Dra. Lenita Tallarico, Dra. Juliana Branco Novo, Dr. Geraldo Santana Magalhães, Dra. Mariana Lopes dos Santos, pelo incentivo.

Aos Mestres - Dr. Osvaldo Augusto Sant'Anna, Dra. Mayana Zatz, Dr. Heitor Franco de Andrade Jr., Dr. Luiz Augusto C. Passos, Dr. Carlos Frederico M. Menck, Dr. Alysson Renato Muotri, Dra. Myriam Krasilshik, Dr. Vojislav 
Aleksandar Jovanovik, Dr. Oswaldo Keith Okamoto, Dr. Uriel Duarte, Dra. Cibele Bugno Zamboni, pela inspiração.

A todos da CPG pela atenção, apoio e orientação técnica.

Á Dra. Ameae Walker, da Universidade da Califórnia - EUA, pela idéia original da produção de antagonista de prolactina de camundongo.

Ao IPEN, FAPESP (projeto 2007/59540-3), CNPq, CAPES pelo apoio financeiro e técnico.

A todos da minha família pelo apoio, compreensão, companhia e incentivo. 


\title{
SÍNTESE E CARACTERIZAÇÃO DE PROLACTINA DE CAMUNDONGO (mPRL) E DE SEU ANÁLOGO (S177D-mPRL)
}

\author{
Miriam Fussae Suzuki
}

\section{RESUMO}

A prolactina é um neurohormônio que faz parte da superfamília das citocinas e está envolvida em inúmeros processos biológicos. Devido à sua ação endócrina, autócrina e parácrina, a prolactina está muitas vezes relacionada ao desenvolvimento de patogenias humanas como carcinomas e doenças autoimunes. Considerando-se que: a) diferença de $41 \%$ encontrada na sequência de aminoácidos da prolactina de camundongo em relação à humana, b) diferenças na glicosilação, fosforilação, e ligação ao receptor e, c) o fato que os modelos animais utilizados em ensaios in vivo com prolactina humana são geralmente ratos ou camundongos (modelos heterólogos), fica evidente que esses fatores podem interferir na interpretação dos resultados. Portanto, experimentos em sistemas homólogos seriam desejáveis. Esse trabalho descreve a obtenção pela primeira vez da $\mathrm{mPRL}$ no espaço periplásmico bacteriano, portanto na sua forma autêntica, ou seja, sem a metionina inicial, com expressão de $0,1 \pm 13,2 \%$ $\mu \mathrm{g} / \mathrm{mL} / A_{600}$. Para isso um vetor de expressão baseado no promotor $\lambda P L$ foi construído e utilizado como promotor constitutivo, com ativação a $37^{\circ} \mathrm{C}$. Um processo de fermentação em biorreator, com rendimentos de expressão de até $2,5 \mu \mathrm{g} / \mathrm{mL}$, e um processo de purificação com três etapas: concentração e purificação por hidrofobicidade (Phenyl Sepharose CL-4B) seguida por HPLC de fase reversa e HPSEC, foram também desenvolvidos. A mPRL purificada foi caracterizada por técnicas físico-químicas e biológicas em comparação com o padrão de referência da $\mathrm{mPRL}$ recombinante do Instituto Nacional de Saúde $(\mathrm{NIH}$, EUA). A atividade biológica foi analisada e sua potência calculada foi de 33,9 \pm $1,4 \mathrm{Ul} / \mathrm{mg}$. O mesmo vetor foi utilizado para a expressão do antagonista S177DmPRL, mas o baixo nível de expressão obtido inviabilizou a sua produção no espaço periplásmico de bactérias. Como alternativa, optamos por produzir essa proteína em células $\mathrm{CHO}$ e clones com expressão da ordem de $1 \mu \mathrm{g} / \mathrm{mL} /$ dia foram obtidos. Com a expressão tanto da mPRL autêntica, como do S177D-mPRL, está aberto o caminho para o desenvolvimento dos estudos que envolvam modelos animais onde a mPRL e seu antagonista sejam fatores relevantes a serem considerados. 


\title{
SYNTHESIS AND CHARACTERIZATION OF MOUSE PROLACTIN (MPRL) AND OF ITS ANALOG (S177D-mPRL)
}

\author{
Miriam Fussae Suzuki
}

\begin{abstract}
Prolactin is a neurohormone included in cytokine superfamily and involved in innumerous biological processes. Due to its endocrine, autocrine and paracrine action, it is, frequently, related to development of human pathologies, such as carcinomas and autoimmune diseases. Considering some factors: a) the difference of $41 \%$ between the amino acid sequence of mouse prolactin in relation to the human one, b) glycosylation, phosphorylation and receptor ligation differences, and c) the fact that the animal model used for in vivo assays with human prolactin are generally rats or mice (heterologous), it is evident that these factors might interfere in the interpretation of results. Therefore, experiments with homologous systems are desirable. This work describes, for the first time, the expression of mouse prolactin in the periplasmic space of bacteria, in its authentic form, i. e., without initial metionine, showing expression levels of $0.1 \pm 13.2 \%$ $\mu \mathrm{g} / \mathrm{mL} / \mathrm{A}_{600}$. For this purpose, an expression vector based on $\lambda P L$ promoter was constructed and used as a constitutive form, with activation at $37^{\circ} \mathrm{C}$. A fermentation process in bioreactor, with expression yields up to $2.5 \mu \mathrm{g} / \mathrm{mL}$, and purification process with three steps: concentration and purification by hydrophobicity (Phenyl Sepharose CL-4B) followed by reverse phase HPLC and HPSEC, were also developed. The $\mathrm{mPRL}$ was purified and characterized by chemo physical and biological techniques compared to the recombinant standard reference from the National Institute of Health (NIH, USA). Its biological activity was analyzed and the calculated potency was $33.9 \pm 1.4 \mathrm{UI} / \mathrm{mg}$. The same vector was used for the expression of S177D-mPRL antagonist, but the low expression level obtained makes it impracticable to produce this protein in the periplasmic space of bacteria. As an alternative, the S177D-mPRL was produced in $\mathrm{CHO}$ cells and clones with expression level of about $1 \mu \mathrm{g} / \mathrm{mL} /$ day were obtained. The expression of both proteins, the authentic mPRL and the S177D-mPRL, opens the door for developing studies with animal models if $\mathrm{MPRL}$ and its antagonist might be considered relevant factors.
\end{abstract}




\section{Sumário}

Página

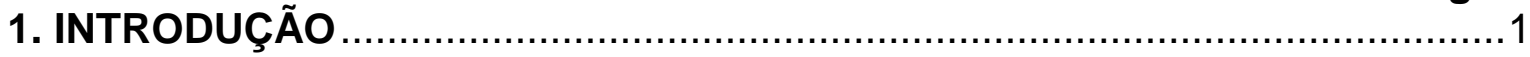

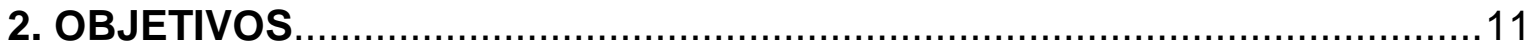

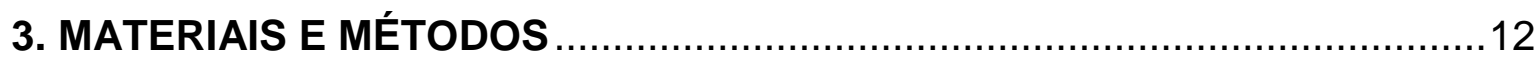

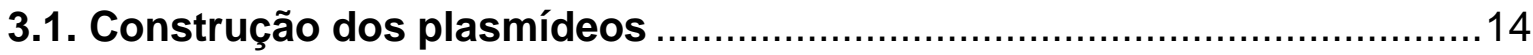

3.1.1 Plasmídeos para expressão em Escherichia coli................................ 14

3.1.2 Plasmídeos para expressão em células de mamíferos.......................18

3.1.2.1. Construção do vetor p658-S177D-mPRL .................................... 18

3.1.2.2. Construção do vetor pEDdc-S177D-mPRL .................................21

3.2. Transformação e expressão em Escherichia coli ................................22

3.3 Transfecção e expressão em células de mamíferos ..............................23

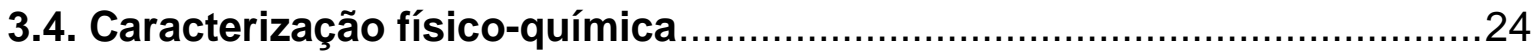

3.4.1. Análise por SDS-PAGE, dot blot e Western Blotting .........................24

3.4.2. Cromatografia líquida de alto desempenho em fase reversa (RP-HPLC)

3.4.3. Cromatografia líquida de alto desempenho por exclusão molecular (HPSEC)

3.5. Cultivo em biorreator da linhagem transformada de W3110 Escherichia coli. .25

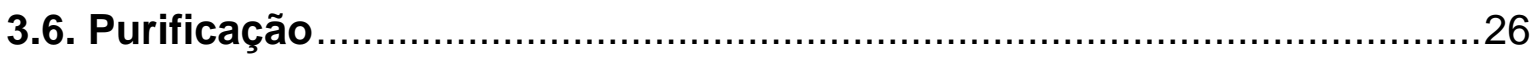

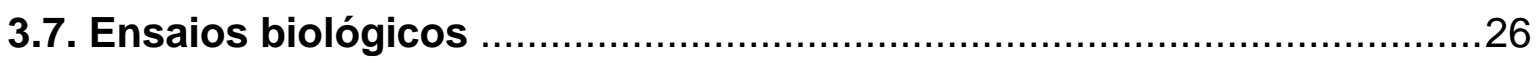

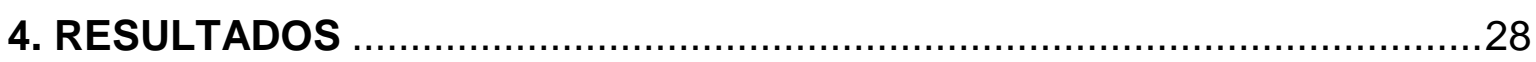

4.1. Caracterização do padrão de r-met-mPRL (NIH/NIDDK) ........................28

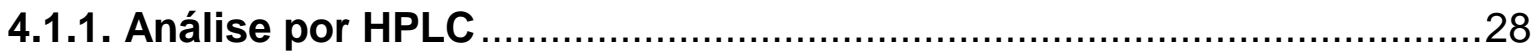

4.1.2. Análise por SDS-PAGE e Western Blotting da mPRL .......................31

4.1.3. Avaliação da atividade biológica da r-met-mPRL .............................32

4.2. Construção dos vetores bacterianos para a expressão da mPRL e de seu análogo/antagonista (S177D-mPRL) ............................................. 34

4.2.1. Análise com enzimas de restrição.................................................34

4.2.2. Sequenciamento do cDNA correspondente à $\mathrm{mPRL}$ e ao antagonista S177D-mPRL. 
4.3. Transformação e expressão da $\mathrm{mPRL}$ e do seu análogo/antagonista S177D mPRL

4.3.1. Caracterização da $\mathrm{mPRL}$ após purificação parcial .43

4.4. Estudos alternativos com objetivo de incrementar a expressão bacteriana 44

4.4.1. Influência da temperatura de cultivo sobre a expressão da mPRL ......44

4.4.2. Análise do lisado bacteriano. 45

4.4.3. Estudos com a cepa Rosetta-gami B

4.5. Análise da expressão da mPRL no periplasma de $E$. coli em biorreator 49 4.6. Purificação da $\mathrm{mPRL}$ produzida no biorreator .50

4.6.1. Concentração e primeira purificação da $\mathrm{mPRL}$ presente no fluido periplásmico .50

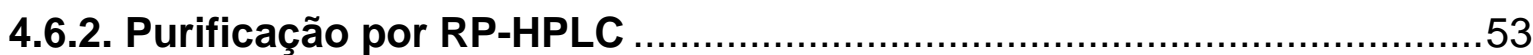

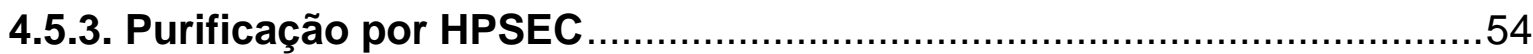

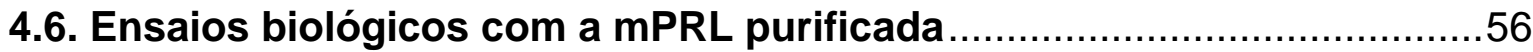

4.7. Construção dos vetores para células de mamífero ……..........................57

4.7.1. Construção do vetor p658-S177D-mPRL ……................................57

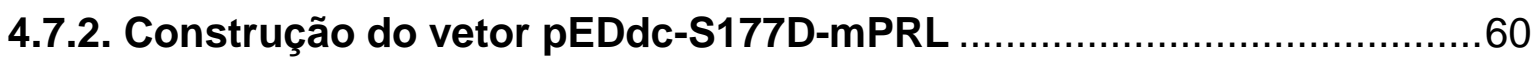

4.8. Expressão do antagonista S177D-mPRL em células de mamíferos........63

4.8.1. Transfecção transiente em células $\mathrm{CHO}-\mathrm{K} 1$ e COS-7 …........................63

4.8.2. Transfecção permanente em células $\mathrm{CHO}$ dhfr- .................................65

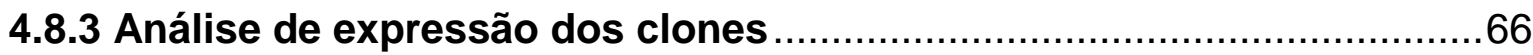

5. DISCUSSÃO

6. CONCLUSÕES

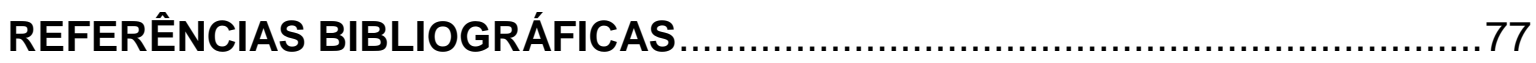




\section{LISTA DE ABREVIATURAS}

aa - aminoácidos

$\mathrm{CHO}$ - ovário de hamster chinês

CPM - contagem por minuto

dhfr - diidrofolato redutase

hPRL - prolactina humana

HPSEC - cromatografia líquida de alto desempenho por exclusão molecular

$\mathrm{mPRL}$ - prolactina de camundongo

MTX - metotrexato

OMS - Organização Mundial da Saúde

$\mathrm{r}$-hPRL - prolactina humana recombinante

r-met-mPRL - prolactina de camundongo recombinante com metionina inicial

RP-HPLC - cromatografia líquida de alto desempenho em fase reversa

SCC - soro de cavalo castrado

SDS-PAGE - eletroforese em gel de poliacrilamida com sódio dodecil sulfato

SFB - soro fetal bovino

SFBd - soro fetal bovino dialisado

TCA - ácido tricloroacético

WB - Western Blotting

Este trabalho seguiu as orientações contidas no guia abaixo:

Igami, M.P.Z.; Zarpelon, L.M.C. (Org). Guia para a elaboração de dissertações

e teses: preparado para orientação dos alunos de Pós-graduação do IPEN. São Paulo: IPEN, Divisão de Informação e Documentação Científicas, 2002. Disponível em <http://www.ipen.br/biblioteca/apresentacao_guia.htm>. Acesso em: 20/08/2008. 


\section{INTRODUÇÃO}

A prolactina é um hormônio proteico envolvido em mais de 300 processos fisiológicos que incluem osmorregulação, reprodução e imunorregulação (Bernichtein e col., 2010; Freeman e col., 2000; Sinha, 1995). Este hormônio apresenta uma grande importância diagnóstica especialmente nos casos de mulheres com problemas de lactação e infertilidade, distúrbios menstruais, hipogonadismo, galactorréia e redução da libido (Glezer e col., 2006), assim como níveis elevados de prolactina foram relacionados com um aumento do risco de câncer de mama em mulheres pré e pós-menopausadas que apresentem tumores com receptores para estrógeno (Hankinson e col., 1999; Tworoger e col., 2004; Tworoger e Hankinson, 2006; Tworoger e col., 2006; Tworoger e Hankinson, 2008). Não há evidências de que haja relação entre níveis plasmáticos de prolactina e câncer de próstata (Stattin e col., 2001). São considerados níveis normais de prolactina sérica nas mulheres $10-28 \mathrm{ng} / \mathrm{mL}$ e nos homens, $5-10$ $\mathrm{ng} / \mathrm{mL}$. A hiperprolactinemia atinge $0,4 \%$ da população em geral e $17 \%$ das mulheres com problemas reprodutivos (Crosignani, 1999).

A síntese e secreção deste hormônio se dão principalmente na parte anterior da hipófise. A prolactina em mamíferos é uma proteína de cadeia simples com cerca de 200 resíduos de aminoácidos (FIG. 1), três pontes dissulfeto e $4 \alpha$ hélices (Sinha, 1995; Utama e col., 2009). Há várias isoformas da prolactina produzidas na hipófise sendo a majoritária de 23 kDa (Sinha e col., 1987).

Embora possíveis aplicações terapêuticas da PRL ainda estejam em fase de estudo, sua utilização em campo diagnóstico e de pesquisa determina um alto valor agregado seja da $\mathrm{PRL}$ humana ( $\mathrm{PRR}$ ) que da prolactina de camundongo (mPRL) comercializadas no mercado internacional por até 5 mil dólares 0 miligrama (http://www.biocompare.com). 


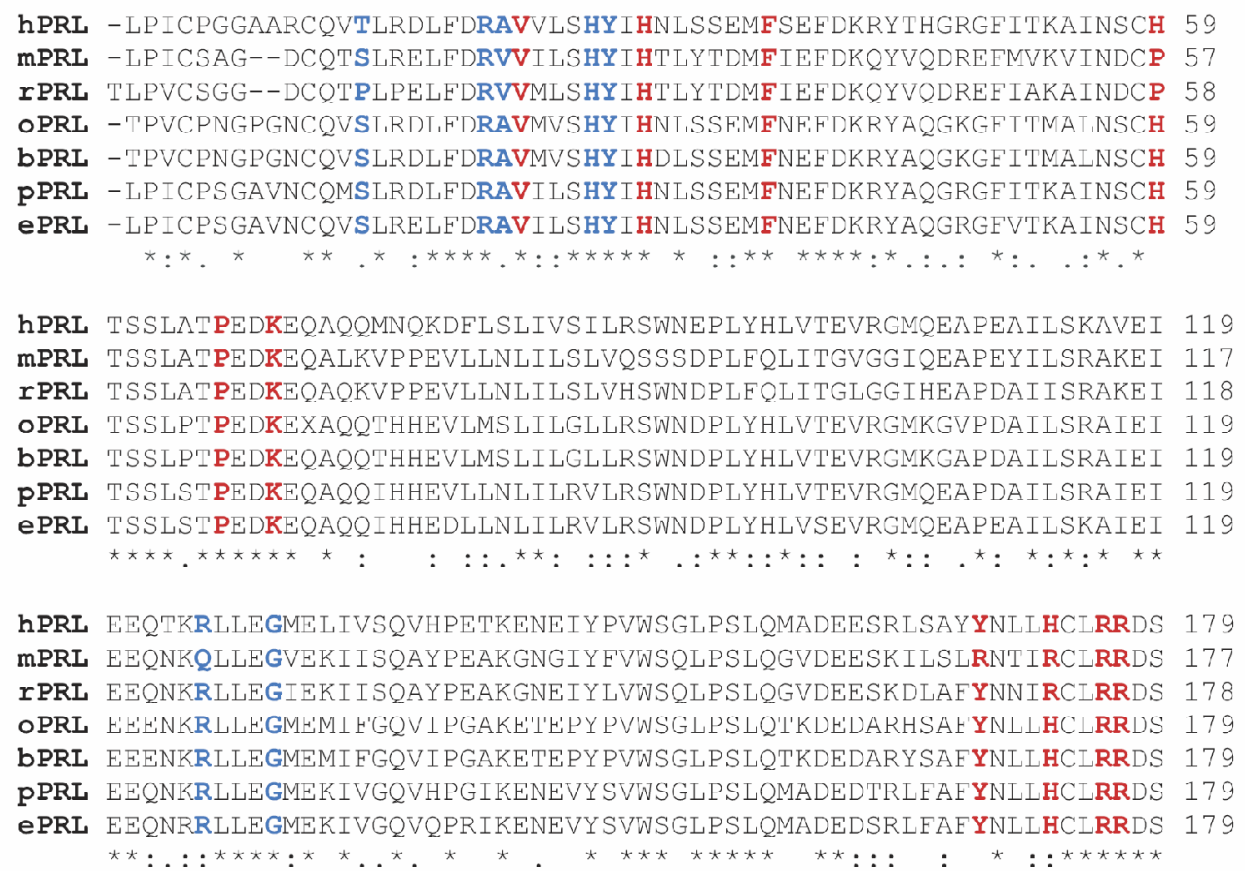

hPRL HKIDNYLKLLECRIIHNNNC 199

MPRI HKVDNFLKVLRCQIAHQNNC 197

rPRL HKVDNYLKFLRCOIVHKNNC 198

OPRI SKIDTYLKLLNCRIIYNNNC 199

bPRL SKIDTYLKLLNCRI I YNNNC 199

PPRI HKIDNYLKLLECRIIYDSNC 199

EPRL HK ||NYI,KLI|KCKIVYI)SNC 199

FIGURA 1. Sequência alinhada de aminoácidos de $P R L$ de várias espécies: humana ( $h P R L$ ), de camundongo ( $m P R L$ ), de rato ( $r P R L)$, ovina (oPRL), bovina (bPRL), porcina ( $p P R L$ ) e equina (ePRL). Os resíduos de aminoácidos que entram em contato direto com o sítio 1 do receptor (hPRLR) estão indicados em vermelho e com o sítio 2 estão indicados em azul (Utama e col., 2009).

A prolactina foi assim denominada por Stricker e Grueter, em 1928, devido a sua função de estimular a produção de leite pelas glândulas mamárias após administração de extrato hipofisário em coelhas (Stricker e Grueter citado por Sinha, 1995, p. 354). Nicoll, em 1967, publicou o primeiro bioensaio medindo e pesando o papo de pombas após injeções intradérmicas de prolactina (Nicoll citado por Tanaka e col., 1980, p. 1058). Já o primeiro radioimunoensaio para prolactina humana (hPRL) foi publicado em 1971 (Hwang e col., 1971). Neste mesmo ano, a hPRL foi isolada e caracterizada (Lewis e col., 1971).

As mais recentes publicações mostram que a prolactina também apresenta ações relacionadas à supressão da fertilidade durante a amamentação, estímulo 
do comportamento maternal, supressão da resposta ao estresse, estímulo da produção de mielina nos neurônios do sistema nervoso central e geração de novos neurônios no bulbo olfativo (Grattan e Kokay, 2008).

Embora a maior fonte de PRL seja a hipófise, a PRL e/ou seu RNA mensageiro (mRNA) são encontrados em uma variedade de tecidos (como as células do sistema imune, baço, timo e placenta) em diferentes organismos vertebrados (de peixes a mamíferos) (Ben-Jonathan e col., 1996). A presença da $P R L$ nestes tecidos se deve não apenas à $P R L$ circulante, mas a sua síntese, secreção e ação autócrina e/ou parácrina.

A prolactina faz parte da superfamília das citocinas tipo 1 que inclui muitas interleucinas e ciclinas. Possui ação direta no controle do ciclo celular, promoção da diferenciação e na iniciação do processo de apoptose (Walker, A. M., 2001; 2007). Também apresenta um papel relevante no desenvolvimento de uma variedade de tumores de próstata e mama (Llovera e col., 2000; Schroeder e col., 2002), na modulação de respostas imunes relacionadas com doenças autoimunes e inflamatórias (Wang e Walker, 1993; Walker, A. M. e col., 1995; Walker, S. E. e col., 1998, Walker, S. E. e Jacobson, 2000; De Bellis e col., 2005; Labriola e col., 2007) e está envolvida numa possível ação na formação de tecidos vasculares (angiogênese). Já a isoforma de $16 \mathrm{kDa}$, produto da clivagem proteolítica da porção $\mathrm{N}$-terminal desta molécula, apresenta uma ação antiangiogênica, (Ferrara e col., 1991; Clapp e col., 1993; Duenas e col., 1999). Além destas atividades, a PRL também estimula a secreção de insulina nas ilhotas pancreáticas no cultivo in vitro (Nielsen, 1982) e in vivo (Brelje e col., 2008).

Devido a sua ação endócrina, autócrina e parácrina, muitas vezes relacionadas ao desenvolvimento de patogenias humanas como carcinomas e doenças auto-imunes (Ben-Jonathan e col., 1996; Fernandez e col., 2010), muitos estudos foram direcionados na busca de um antagonista eficiente dessa proteína, capaz de inibir ou eliminar essas ações não desejadas (Goffin e col., 2003; Goffin e col., 2005; Hansen e col., 2010; Walker, A. M., 2006). O controle da secreção endócrina pode ser realizado por meio de drogas agonistas de dopamina como a bromocriptina (Walker, S. E., 2001a; b) que inibem a síntese e liberação da prolactina pela hipófise. Essa terapia, no entanto, não tem ação sobre a síntese nos tecidos extra-hipofisários e na ação parácrina e autócrina. 
O desenvolvimento de antagonistas visa agir, portanto, sobre a ligação da prolactina com seu receptor de forma a modular ou impedir sua ação parácrina, autócrina e endócrina (Wang e Walker, 1993; Bernichtein e col., 2003). São conhecidos vários antagonistas de prolactina: o G129R-hPRL (glicina 129 substituída por arginina), S179D-hPRL (serina 179 substituída por ácido aspártico), $\triangle 41-51-\mathrm{hPRL}$ (deleções dos aminoácidos 41 a 51) (Depalatis e col., 2009), $\Delta$ 1-9-G129R-hPRL e $\Delta$ 1-14-G129R-hPRL (deleções de 9 e 14 resíduos Nterminais), incluindo o G120R-hGH também antagonista do hGH, que possui uma ação lactogênica (Chen, T. J. e col., 1998; Goffin e col., 2003; Soares e col., 2006). Estas moléculas bloqueiam ou alteram a interação da prolactina com o seu receptor de membrana (PRLR) e impedem ou alteram a dimerização deste receptor influenciando a ativação das vias de sinalização intracelular, tais como a via Jak/Stat, ERK e MAPK (Wu e col., 2003; Wu e col., 2006). Desta forma a ação destes análogos da PRL pode ser de antagonista ou agonista, dependendo da concentração e do tipo celular testado (Gertler, 1997, Goffin e col., 2002, Tallet e col., 2008). O estudo destas moléculas tem mostrado aumento e redução de expressão de várias proteínas e de seus RNA mensageiros (STAT1, STAT3, p44/42, p38, p21, VDR) quando avaliados os resultados obtidos in vitro e in vivo (Walker, A. M., 2006; Terasaki e col., 2010; Xie e col., 2010).

O antagonista S179D-hPRL desenvolvido por Walker e colaboradores (Wang e Walker, 1993; Chen, T. J. e col., 1998), foi idealizado com base na estrutura da prolactina fosforilada, cuja ação antagonista foi obtida pela substituição de uma serina (179) normalmente fosforilada por um resíduo de aspartato. Quando utilizado alanina nesta mesma posição, S179A-hPRL, não houve ação nem agonista, nem antagonista. Já a substituição por valina, S179VhPRL, resulta em uma ação agonista. A fosforilação da prolactina foi observada em camundongos (Horiguchi e col., 2007a), ratos, humanos (Oetting e col., 1986; Aramburo e col., 1992), galinhas, perus (Aramburo e col., 1992) e bovinos (Brooks e col., 1990). A PRL fosforilada antagoniza a ação proliferativa da prolactina não modificada em ensaios com as células de linfoma de rato Nb2 (Wang e Walker, 1993). A forma não modificada pode regular a secreção de $P R L$ que suprime a liberação da mesma forma não fosforilada pelas células GH3, linhagem celular secretora de PRL da hipófise anterior de ratos, mediante mecanismo de feedback (Krown e col., 1992). A proporção entre a forma fosforilada e a não-fosforilada 
varia de acordo com o estado fisiológico em ratos, sendo a forma não-fosforilada predominante na fase de estro (Ho e col., 1993). Em humanos a fosforilação principal se dá na serina 179 e a secundária, provavelmente, na treonina 63 (Walker, A. M., 1994). No rato a primária ocorre na serina 177 e a secundária ocorre na treonina 58 e 63 (Wang e col., 1996). Em bovinos a fosforilação primária ocorre na serina 90 e secundariamente nas serinas 26 e 34 (Kim e Brooks, 1993). Em camundongos a prolactina é fosforilada na serina 177 e na treonina (não foi descrita se ocorre na posição 58 ou 63), apresentando-se em três isoformas: não fosforilada, fosforilada na serina e fosforilada na serina e treonina (Horiguchi e col., 2007a; Horiguchi e col., 2007b). A secreção da forma fosforilada em serina e não em treonina, foi descrita em pacientes com macroprolactinemia (Hattori e col., 2005). Este mesmo antagonista da hPRL, 0 S179D-hPRL, em estudos realizados em colaboração entre o nosso e o laboratório que primeiro o sintetizou (Universidade da California, Riverside), mostrou também possuir propriedades anti-angiogênicas, influenciar a expressão de proteínas reguladoras do ciclo celular e induzir a apoptose através da via extrínseca (Ueda, E. e col., 2006; Ueda, E. K. e col., 2006; Wu e col., 2006). Posteriormente foram também realizados estudos relativos à sua conformação e à influência desta na transmissão intracelular do sinal (Ueda e col., 2009).

Um dos interesses maiores relativamente à utilização de antagonistas de prolactina, além do tratamento de câncer de mama ou próstata (Xu e col., 2001; Chen, N. Y. e col., 2002; Schroeder e col., 2003), está no possível tratamento de doenças crônicas como o lúpus eritematoso sistêmico e a artrite reumatóide (Goffin e col., 2005; Chuang e Molitch, 2007). No caso do lúpus eritematoso sistêmico (SLE), uma doença autoimune de causa desconhecida, níveis anormais de citocinas produzidas por células $T$, hiperatividade das células $B$, anticorpos antinucleares, formação e deposição de complexos imunes levando a artrite, eritema, serosite e glomerulonefrite foram relatados. Esta patologia afeta mais mulheres que homens durante a fase reprodutiva e os sintomas são exacerbados quando da menstruação, uso de contraceptivos orais, gravidez, metabolismo alterado de estrógenos e andrógenos e na hiperprolactinemia (Jacobi e col., 2001; Grimaldi, 2006). O camundongo (NZB x NZW)F1 desenvolve SLE com sintomatologia análoga ao humano sendo que as fêmeas a apresentam em idade menor que os machos (Mcmurray e col., 1994; Elbourne e col., 1998). O 
tratamento com antagonista da prolactina humana (S179D-hPRL) neste modelo animal aumentou o tempo de sobrevida, da mesma forma que a administração de bromocriptina (Walker, S.E. e col., 1999). A hipótese por nós levantada é a de que uma ação mais efetiva, ou de qualquer forma, mais confiável, poderia ser obtida com o uso de antagonista de camundongo (S177D-mPRL) sendo que o antagonista humano, além de apresentar uma diferente afinidade para o receptor, deverá certamente induzir uma ação imunogênica, com conseqüente redução de potência, uma vez que a diferença entre a prolactina humana e de camundongo reside de fato em 82 aminoácidos (Kohmoto e col., 1984) ou 41\% de diferença na sequência (Utama e col., 2006; Utama e col., 2009) (FIG. 1).

Considerando-se a diferença de $41 \%$ encontrada na sequência de aminoácidos da prolactina de camundongo em relação à humana, implicando também em diferenças na glicosilação e fosforilação, assim como na sua ligação ao receptor e, ainda, levando-se em conta que os modelos animais utilizados em ensaios in vivo com prolactina humana são geralmente heterólogos (ratos ou camundongos), fica evidente que esses fatores podem interferir de forma decisiva na interpretação correta dos resultados e que experimentos em sistema homólogo seriam desejáveis. $O$ desenvolvimento de um antagonista com base na prolactina de camundongo ( $\mathrm{MPRL}$ ) fosforilada envolveria, portanto, a troca do códon da serina 177 pelo do ácido aspártico, simulando artificialmente uma alteração da molécula, visando obter uma ação fisiológica semelhante àquela da $P R L$ fosforilada. $O$ isolamento da forma fosforilada (aproximadamente 20\%) de preparações de PRL (Kim e Brooks, 1993), além de trabalhosa, resulta em pouca quantidade e alto custo que impossibilitam sua aplicação in vivo.

Vários laboratórios descrevem a expressão de hPRL em diferentes células procariotas e eucariotas utilizando diferentes estratégias, como apresentado no artigo de revisão de Ribela e colaboradores (2003). Há um relato da expressão da mPRL no citoplasma de E. coli (Yamamoto e col., 1992), utilizando IPTG para indução da síntese e purificação dos corpos de inclusão e, assim, o produto final apresenta uma metionina inicial (met-mPRL). Ao contrário da expressão no citoplasma, a expressão de proteínas recombinantes no espaço periplásmico apresenta uma série de vantagens como: poucos contaminantes, baixa atividade proteolítica e pequena quantidade ou ausência de isoformas indesejáveis, como moléculas com alto peso molecular, formas glicosiladas, fosforiladas ou clivadas. 
A produção no espaço periplásmico também apresenta a vantagem de levar à extração de apenas $4 \%$ das proteínas totais da bactéria. Este fato reduz 0 trabalho e custo de purificação. Além disso, o peptídeo sinalizador é clivado de forma natural, o que proporciona a retirada da metionina inicial, normalmente presente nas proteínas produzidas no citoplasma bacteriano. $\mathrm{O}$ ambiente oxidante do periplasma facilita a obtenção da conformação correta da proteína (Makrides, 1996; Soares e col., 2003). Há evidências, porém, que nem todas as proteínas podem ser secretadas no espaço periplásmico bacteriano com a mesma eficiência (Soares e col., 2008). Existem também outras desvantagens como a impossibilidade de realizar, nas bactérias, modificações pós-traducionais como a glicosilação e/ou a formação de pontes disssulfeto, em alguns casos. O sucesso da produção pode residir no uso de promotores adequados que resultem em incrementos de $10 \%$ a $30 \%$ da proteína de interesse em relação ao total de proteína da célula. Essa produção, no entanto, não deverá ser tóxica ou ter produtos concomitantes tóxicos (alterar o potencial de membrana) ou que venham a reduzir a produção (inativação de ribossomos). Avanços foram obtidos com a utilização de promotores regulados por temperatura $\left(\lambda \mathrm{P}_{\mathrm{L}}\right)$ e sequências sinalizadoras que transferem a proteína para o periplasma (DsbA) (Soares e col., 2003,). Chou em sua revisão de 2007 apresenta como a manipulação de genes efetores de enovelamento da proteína (como as foldases e as chaperonas), pode aumentar a produção de proteínas. Apresenta desde a utilização de genes ligados à resposta contra estresse (heat shock proteins), a alterações no metabolismo da glicose, ao controle da fase estacionária (rpoS, rmf), até outros relacionados com a co-expressão de outras proteínas heterólogas que combatem a oxidação, favorecem o crescimento e melhoram a síntese de rRNA.

Já foi relatado a expressão periplásmica do hGH e da hPRL em bactérias utilizando o promotor $\lambda P_{L}$ e o peptídeo sinalizador DsbA (Soares e col., 2003; Soares e col., 2008). Esse promotor é bastante utilizado na produção em larga escala, pois, além do baixo custo de produção, não utiliza agentes químicos indutores como o IPTG ou o ácido nalidíxico que podem ser danosos ao ser humano e ao meio ambiente (Makrides, 1996; Soares e col., 2003). No entanto, como descrito por Soares e colaboradores (2008), o promotor $\lambda P_{L}$ utilizado de forma convencional não funcionou no caso da expressão de hPRL. Nesse modelo 
de expressão o cultivo a 42 C é necessário para denaturar o repressor termolábil clts, ativando dessa forma o promotor. No caso da expressão da hPRL, esse modelo se mostrou prejudicial, pois grande parte da $\mathrm{hPRL}$ cultivada a $42^{\circ} \mathrm{C}$ era degradada ainda no citoplasma, antes de atingir o espaço periplásmico. Com base nesses resultados, seria indicada a utilização do promotor $\lambda P_{L}$ sem 0 repressor, ou seja, funcionando como promotor constitutivo. O controle da expressão sendo realizado pela variação de temperatura de $30^{\circ} \mathrm{C}$ para $37^{\circ} \mathrm{C}$ seria tecnicamente fácil, rápida e barata. Esse sistema com controle metabólico da expressão foi bastante eficiente no caso da expressão de hPRL e hGH (Soares e col., 2008). O cultivo a $37^{\circ} \mathrm{C}$ apresenta a vantagem de diminuir a degradação de proteínas susceptíveis à proteólise intracelular. O possível aumento da instabilidade estrutural e segregacional (número de cópias do plasmídeo), podendo facilitar a perda da expressão é uma desvantagem (Soares e col., 2008).

Outra estratégia utilizada para a expressão de proteínas heterólogas é a expressão em células de mamíferos. Esse sistema de expressão, além de ser uma alternativa, no caso da expressão em E. coli não ser satisfatória, possibilita também a obtenção de isoformas como as glicosiladas, normalmente não produzidas por bactérias. As células de ovário de hamster chinês $(\mathrm{CHO})$ são as mais utilizadas para a síntese de biofármacos, especialmente para a obtenção de glicoproteínas terapêuticas (Ribela e col., 2003).

O nosso grupo também possui experiência na síntese de hormônios recombinantes em células CHO. Em Soares e col. (2000) descrevemos a síntese purificação e caracterização da hPRL comparando dois vetores, ambos projetados para utilização em linhagem de células CHO-DXB11. Essa célula tem uma deleção no alelo dhfr. Assim, as células DHFR` requerem glicina, hipoxantina e timidina (GHT) para crescerem. Esse mutante é útil para selecionar células com plasmídeos contendo o gene dhfr em meio de seleção sem nucleosídeos GHT. Um dos vetores, o pEDdc, é um vetor dicistrônico, no qual o mesmo mRNA expressa duas proteínas. Nesse vetor a proteína de interesse está na posição 5' e o gene de seleção/amplificação na posição 3' (Kaufman e col., 1991). Sua vantagem em relação a outros vetores de expressão dicistrônicos da geração anterior é a utilização de um sítio ribossomal interno, isolado do vírus da 
encefalomiocardite (EMC). A inserção da sequência líder do vírus da EMC, antes do gene dhfr, torna a tradução dessa enzima mais eficiente e menos dependente da sequência codificadora localizada "upstream", correspondente ao gene de interesse, o que nos outros vetores dicistrônicos não ocorre. Esta construção possibilita, portanto, a rápida e eficiente obtenção de altos níveis de expressão, após seleção e amplificação gênica, caracterizada pelo aumento gradual na concentração de metotrexato (MTX) no meio de cultivo, diminuindo enormemente a possibilidade de deleção do gene de interesse. O outro vetor de expressão é o p658, que compreende um sistema no qual é possível o isolamento de células altamente produtivas utilizando uma única etapa de seleção. Este sistema é baseado na seleção do gene de interesse em combinação com 0 enfraquecimento do mRNA do gene de seleção (dhfr). Isto aumenta a pressão de seleção, possibilitando a eliminação das várias etapas de amplificação. A expressão do gene de interesse é reforçada pela presença do transativador viral do vírus X da hepatite B (HBV-X), inserido antes do promotor SV40 (p SV40). O enfraquecimento do gene de seleção ocorre pela inserção, logo após o gene do dhfr, da sequência rica em $A+T$ derivada da região 3' não traduzida do fator estimulador de formação de colônias de macrófago-granulócito (GM-CSF UTR), que deixa o mRNA instável, apresentando a vantagem da obtenção do clone de interesse de forma mais rápida. Porém as expressões máximas obtidas, nesse caso, foram sempre aproximadamente $50 \%$ menores que as obtidas com o uso do vetor pEDdc. Em Peroni e colaboradores, está descrita a obtenção de um clone (CHO-hTSH) modificado geneticamente, capaz de expressar tireotrofina humana (hTSH) (Peroni e col., 2002), onde foram utilizados dois plasmídeos dicistrônicos: o pEDdc, contendo o gene correspondente à subunidade alfa do hTSH e o plamídeo pACdc, com o gene da subunidade beta do hTSH. Em Soares e colaboradores (2006) foi desenvolvido um trabalho de síntese e caracterização dos antagonistas da hPRL, o S179D-hPRL e o G129R-hPRL. Nesse trabalho a expressão do antagonista G129R-hPRL teve sucesso nos dois sistemas de expressão: utilizando $E$. coli (promotor $\lambda \mathrm{P}_{\mathrm{L}}$ ) ou células $\mathrm{CHO}$ (vetor p658). Já o antagonista S179D-hPRL foi expresso em quantidades úteis somente no sistema com células $\mathrm{CHO}$. 
Foi, portanto, com base nessa experiência que enfrentamos a presente tarefa ligada a síntese de mPRL e S177D-mPRL. A obtenção da mPRL, do seu antagonista e a respectiva caracterização físico-química e biológica serão, portanto, úteis para estudar o papel da PRL na evolução de doenças crônicas do tipo autoimune em modelos animais, assim como para qualquer outro tipo de pesquisa em que seja necessário o uso de sistemas homólogos. 


\section{OBJETIVOS}

Objetivo geral:

O objetivo deste trabalho é a síntese de prolactina de camundongo ( $\mathrm{mPRL}$ ) e do seu antagonista (S177D-mPRL).

Objetivos específicos:

- Caracterização do padrão de mPRL recombinante (r-met-mPRL) por RPHPLC, HPSEC, SDS-PAGE, WB e atividade biológica in vitro.

- Construção de vetores para expressão de mPRL e S177D-mPRL no espaço periplásmico de Escherichia coli utilizando o promotor $\lambda \mathrm{PL}$.

- Estudos de expressão e caracterização da mPRL e do S177D-mPRL em Escherichia coli.

- Fermentação em biorreator, purificação, caracterização físico-química e biológica da mPRL.

- Construção de vetores para expressão de S177D-mPRL em células de mamífero.

- Obtenção de clones de células CHO para expressão de S177D-mPRL.

Ressaltamos que a síntese da mPRL e do S177D-mPRL no espaço periplásmico de $E$. coli e em células $\mathrm{CHO}$, respectivamente, ainda não foram descritos na literatura. 


\section{MATERIAIS E MÉTODOS}

Os reagentes utilizados para o preparo das soluções foram de grau PA e grau HPLC. As sínteses dos cDNA's foram realizadas pela empresa Genscript (Piscataway - NJ, EUA). As enzimas de restrição BamHI, Ndel, EcoRl, Xbal, Xhol e HindllI, os marcadores de massa molecular, a T4 DNA ligase, a CIAP e a Platinum Taq DNA polimerase High Fidelity foram obtidas das empresas Fermentas, Invitrogen e New England Biolabs para construção e posterior análise dos vetores. Os primers para seqüenciamento e PCR foram obtidos da IDT (EUA). Kits de miniprep, maxiprep e extração de DNA do gel para amplificação dos plasmídeos foram obtidos da Qiagen (Germantown - MD, EUA) e Promega (Madison - WI, EUA). Triptona e extrato de levedura foram obtidos da Becton Dickinson and Company (Sparks - MD, EUA) para cultivo das bactérias E. coli, cepas W3110, DH5a, RB791 e Rosetta-gami B. O padrão de mPRL recombinante (AFP405C) e o soro de coelho anti-mPRL foram obtidos do National Institute of Health/National Institute of Diabetes \& Digestive \& Kidney Diseases (NIH/NIDDK, Torrance - CA, EUA). $\mathrm{O}^{125}$ I foi obtido da MDS Nordion (Ottawa - ON, Canadá). Os meios de cultura para células de mamíferos RPMI 1640, DMEM High Glucose, $\alpha$-MEM sem nucleosídeos, CHO-S-SFM II, soro fetal bovino (SFB) e soro fetal bovino dialisado (SFBd), solução de penicilina/estreptomicina, beta mercaptoetanol e a Lipofectamine ${ }^{\mathrm{TM}}$ foram obtidos da Gibco®/Invitrogen (Grand Island - NY, EUA). Para concentração do meio condicionado foi utilizado tubo de centrífuga com filtro para $3000 \mathrm{Da}$, Amicon® Ultra (Millipore, Billerica, MA - EUA). As membranas de nitrocelulose utilizadas foram da marca Hybond ${ }^{\text {TM }}-\mathrm{C}$ Extra, GE Healthcare Life Sciences, EUA. Foi utilizado o sistema de revelação de membranas por quimioluminescência da ImmobilionTM Western HRP (Millipore, EUA). Para avaliação da proliferação celular, foram utilizados os reagentes: MTS [3(4,5-dimetiltiazol-2-il)-5(3-carboximetoxifenil)-2-(4-sulfofenil)-2H-tetrazolina] da Promega Corporation (Madison - WI, EUA) e metossulfato de fenazina da Sigma (Saint Louis - MO, EUA). Os materiais plásticos utilizados na cultura celular foram da marca Corning ${ }^{\circledR}$ Costar ${ }^{\circledR}$ (Sigma-Aldrich - Saint Louis - MO, EUA). 
Foram utilizados os laboratórios de Cultura Celular, Biologia Molecular e Fermentação do Centro de Biotecnologia (IPEN, CNEN/SP) que possuem Certificados de Qualidade em Biossegurança para trabalho com organismos geneticamente modificados (nível NB-1 e nível NB-1 larga escala). A sala de Cultura Celular é composta de três incubadoras de $\mathrm{CO}_{2}$, dois tanques de nitrogênio, dois fluxos laminares e dois microscópios invertidos. O laboratório de Biologia Molecular possui os seguintes equipamentos: centrífugas de mesa, transiluminador UV, eletroporador, banho-maria, fonte e cuba de eletroforese. No laboratório de Fermentação há um biorreator piloto de $20 \mathrm{~L}$, para bactéria (MBR, Zurich, Suíça), espectrofotômetro, dois agitadores rotacionais com controle de

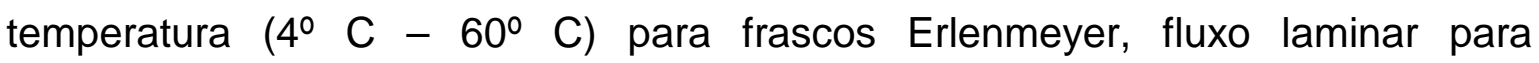
manipulação de bactérias, uma centrífuga refrigerada (marca Sorvall - modelo RC 5B plus).

Foram também utilizados dois sistemas completos de HPLC (Shimadzu), um contador gama (Packard) e uma sala "quente" com capela controlada para marcação de proteínas com ${ }^{125} \mathrm{I}$ e sistema cromatográfico para purificação de produtos radiomarcados. O laboratório de purificação de proteínas com três sistemas cromatográficos completos com coletores de frações (GE-Pharmacia), acondicionados em três geladeiras $\left(4^{\circ} \mathrm{C}\right)$, destilador e purificador de água tipo Milli-Q. O laboratório para eletroforese é utilizado para a realização de SDSPAGE, WB e Dot Blot (BIO-RAD, Hercules - CA, EUA) e conta com sistemas completos para eletroforese e transferência semi-seca. O laboratório dispõe ainda de uma centrífuga preparativa Sorvall - modelo RC2-B (Ramsey, Minnesota, EUA), três autoclaves, banho-maria, hot blot, leitor de microplacas de bancada (Thermo Scientific Multiscan EX), geladeiras e freezers $\left(-80^{\circ} \mathrm{C},-40^{\circ} \mathrm{C}\right.$ e $\left.-20^{\circ} \mathrm{C}\right)$.

O sequenciamento do DNA utilizando o equipamento MegaBACE 1000 (GE Healthcare) e a quantificação dos plasmídeos e fragmentos de DNA por Nanodrop® foram realizados no Centro de Estudos do Genoma Humano - IBUSP, São Paulo - SP. 


\subsection{Construção dos plasmídeos}

\subsubsection{Plasmídeos para expressão em Escherichia coli}

O DNA contendo a sequência correspondente ao sítio de restrição da enzima Ndel, códon de iniciação, peptídeo sinalizador DsbA, cDNA da mPRL com a sequência nativa do hormônio (NCBI Reference Sequence NM_011164.2, Mus musculus prolactin - cDNA Prl), stop codon e o sítio de restrição BamHI foi inserido no cassete de expressão desenvolvido em nosso laboratório, o mesmo utilizado para obter o vetor do hGH ( $\left.\lambda P_{L}-D s b A-h G H\right)$ (Bartolini e col., 04/11/2004 Patente $\mathrm{PI}$ 0406443-7). Esse cassete contém o promotor $\lambda P_{L}$ e o gene para resistência à ampicilina (Soares e col., 2003). O vetor foi chamado de $\lambda P_{L}-D s b A-$ mPRL (FIG. 2). Outro vetor contendo a mutação que codifica o ácido aspártico (D) na posição 177 da serina $(S)$ foi também construído e denominado $\lambda P_{L}$-DsbAS177D-mPRL. Essas duas sequências são apresentadas na FIG. 3 e foram sintetizadas pela GenScript Corporation (Piscataway - NJ - EUA) no cassete de expressão pUC57. Foram fornecidos também comprovantes dos seqüenciamentos e outras informações necessárias sobre o vetor pUC57.

Os cassetes obtidos foram amplificados em bactérias $E$. coli cepa $\mathrm{DH} 5 \mathrm{a}$ e depois utilizados para transformar a cepa de expressão W3110, RB791 e Rosettagami -B. 


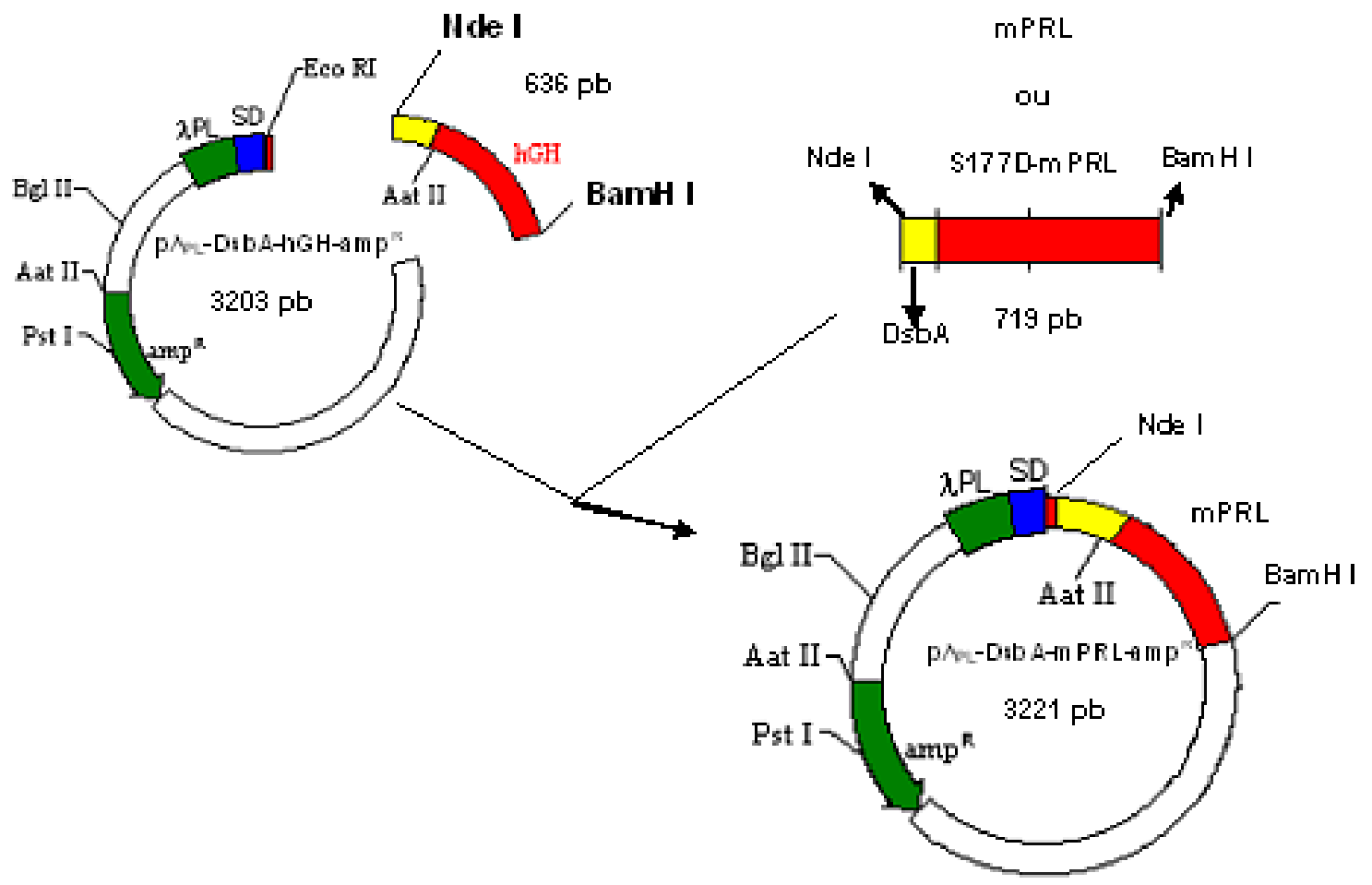

FIGURA 2. Esquema de construção do vetor bacteriano para expressão de mPRL ou de seu análogo S177D-mPRL, por substituição da sequência correspondente ao hormônio de crescimento humano (hGH). 


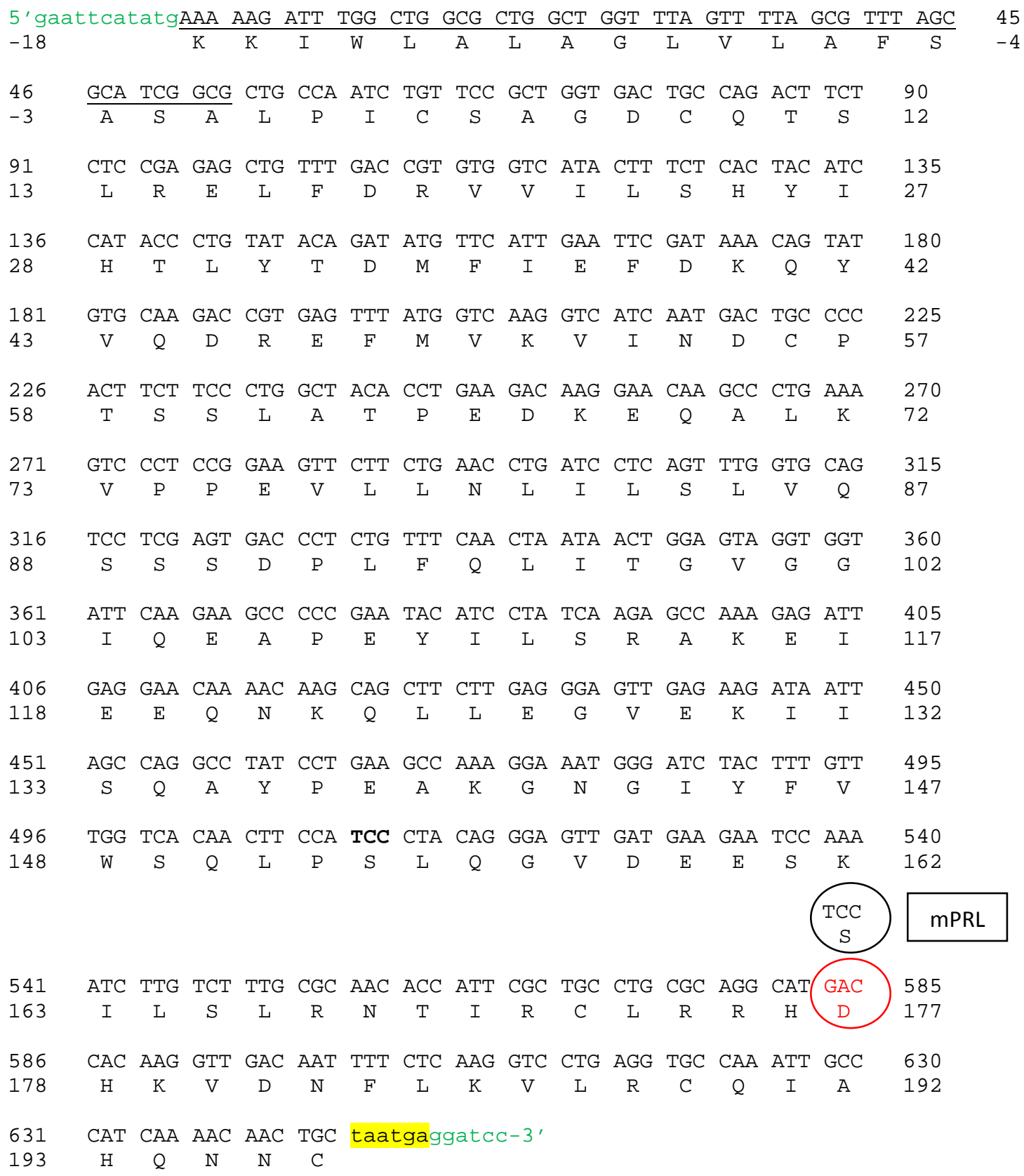

FIGURA 3. Sequência de nucleotídeos e aminoácidos (aa) da DsbA-mPRL, onde em verde temos os sítios de restrição das enzimas EcoRI e Ndel, (extremidade 5') e BamHI (extremidade 3’); A sequência correspondente ao peptídeo sinalizador DsbA com 18 aa está sublinhada. O cDNA da mPRL teve sua sequência obtida no site da NCBI Reference Sequence: NM_011164.2 Mus musculus prolactin (Prl). O stop codon duplo está destacado em amarelo. No caso do análogo, o códon "GAC" correspondente ao ácido aspártico (posição 177) está destacado em vermelho, enquanto no caso da mPRL temos o códon "TCC" correspondente a serina. 
Para o sequenciamento do plasmídeo sintetizado pela Genscript no cassete de expressão pUC57 e do plasmídeo obtido pela substituição da sequência do hGH pela da mPRL e S177D-mPRL no cassete de expressão $\lambda P_{L^{-}}$ DsbA, foram desenhados e sintetizados seis primers (IDT Technology, EUA), sendo dois externos à sequência da $\operatorname{mPRL}(\mathrm{a}$ e b) e quatro internos (c - f):

a) 5'-AGCATTGGTTAAAAATTGGAGG-3' (forward)

b) 5'-AAGCTTGCATGCCTGCAGG-3' (reverse)

c) 5'-TGATCCTCAGTTTGGTGCAGTCCT-3' (forward)

d) 5'-TCTCCGAGAGCTGTTTGACC-3' (forward)

e) 5'-TTGGCACCTCAGGACCTTGAGAAA-3' (reverse)

f) 5'-TTCAGGGCTTGTTCCTTGTC-3' (reverse)

Os primers externos ao gene da $\mathrm{MPRL}$ apresentam uma vantagem prática, já que eles poderão ser utilizados para seqüenciar outros genes que utilizem o mesmo cassete de expressão.

O sequenciamento foi realizado pelo Centro de Estudos do Genoma Humano (IB - USP, São Paulo - SP), utilizando o MegaBACE 1000, um sistema de análise de DNA de 96 capilares com a tecnologia GE Healthcare (antiga Amersham Biosciences). As amostras de $5 \mu \mathrm{L}$ de plasmídeos na concentração de $100 \mathrm{ng} / \mu \mathrm{L}$ foram entregues misturados a $2,5 \mu \mathrm{L}$ de primer na concentração de 5 $\mu \mathrm{M}$ (ou 5 pmoles/ $\mu \mathrm{L}$ ). As amostras foram diluídas em água ultrapura.

Utilizamos os programas BioEdit - versão 7.0.9.0 (Hall, 1999), Chromas versão 2.33 (www.technelysium.com.au) e BLAST (NCBI, http://blast.ncbi.nlm.nih.gov/Blast) para comparação das sequências. A construção também foi confirmada por análise de restrição.

Os primers (d) e (e) foram utilizados nas reações de PCR para confirmar a presença do gene da mPRL e do S177D-mPRL. 


\subsubsection{Plasmídeos para expressão em células de mamíferos}

Para a expressão do antagonista S177D-mPRL em células CHO utilizamos dois sistemas baseado nos vetores: p658 e o pEDdc, ambos já utilizados para a expressão de hPRL (Soares e col., 2000), ambos contendo o gene de seleção da enzima diidrofolato redutase (dhfr). O p658 apresenta a vantagem de não necessitar da etapa de amplificação gênica, pois logo após a seleção é possível obter a expressão máxima. Já o pEDdc necessita da etapa de amplificação gênica utilizando metotrexato (MTX), um processo trabalhoso e que exige mais tempo, porém proporcionando uma expressão final bem maior.

Para essas novas construções optamos por utilizar o peptídeo sinalizador natural da hPRL, o mesmo utilizado em outros trabalhos (Soares e col., 2000; Soares e col., 2006).

\subsubsection{Construção do vetor p658-S177D-mPRL}

O vetor p658-S177D-mPRL foi construído a partir do vetor p658-hPRL obtido em trabalho de colaboração entre pesquisadores do nosso grupo e a empresa Sanofi, realizado no laboratório de pesquisa localizado em Labege França. Para essa nova construção foram estudadas diferentes estratégias em decorrência de algumas dificuldades técnicas como: poucas alternativas de sítios de clonagem; presença do gene da hPRL que é muito semelhante com o gene do antagonista de $\mathrm{mPRL}$; presença de dois sítios para a enzima BamHI, uma das enzimas utilizadas para a retirada do gene correspondente a $h P R L$, no vetor p658-hPRL.

Estratégia 1: Digestão total com as enzimas BamHI/Hindlll e reação de tri-ligação

A digestão completa do p658-hPRL com as enzimas BamHI e Hindlll gera três fragmentos com: 4728 pb, 1540 pb e 753 pb, esse último correspondendo ao gene da hPRL. Os dois fragmentos maiores foram purificados e aquele com 4728 pb foi também desfosforilado com a enzima fosfatase alcalina (CIAP - calf intestinal alkaline phosphatase, Fermentas). Esses dois fragmentos, juntamente com o gene do antagonista, retirado do pUC57, completaram as três sequências de DNA necessárias para a reação de tri-ligação. Podemos afirmar que mesmo variando-se as proporções entre fragmentos $(1: 1: 1 ; 1: 2: 1 ; 1: 1: 3)$, não obtivemos sucesso com essa estratégia. 
Estratégia 2: Reação de ligase em duas fases

Outras tentativas foram realizadas, ainda utilizando os três fragmentos de DNA. Consistiram basicamente em duas etapas de reação de ligação, a primeira reação com dois fragmentos, seguida da purificação do produto desejado. Este por sua vez foi então utilizado na segunda reação junto com o terceiro fragmento. Porém, depois de várias tentativas, também não obtivemos sucesso.

Estratégia 3: Digestão parcial com a enzima BamHI

Essa estratégia consiste basicamente na digestão com as enzimas de restrição BamHI e Hindlll para retirada do cDNA da hPRL e substituição pelo gene da S177D-mPRL sintetizado no plasmídeo pUC57 (FIG. 4). Primeiro realizamos a digestão total do vetor p658-hPRL com HindIII, depois uma digestão parcial com a enzima BamHI, seguida da purificação do fragmento com 6070 pb. O fragmento purificado e provavelmente contaminado com o vetor linearizado, ainda contendo o gene da hPRL, foi digerido com as enzimas EcoRl e Xbal, sendo que no p658, só o gene da hPRL possui sítios de restrição para essas enzimas. A idéia é, portanto, clivar o gene residual da hPRL, dificultando o fechamento do vetor ainda com o hPRL. Em seguida realizamos nova purificação, desta vez em gel de poliacrilamida 6\%, resultando no vetor p658 com extremidade BamHI e HindIII, purificado e pronto para a reação de ligação com o inserto S177D-mPRL. Esta estratégia também não funcionou até que fossem introduzidas as duas etapas mencionadas: digestão com as enzimas EcoRl e Xbal e purificação em gel de poliacrilamida. 


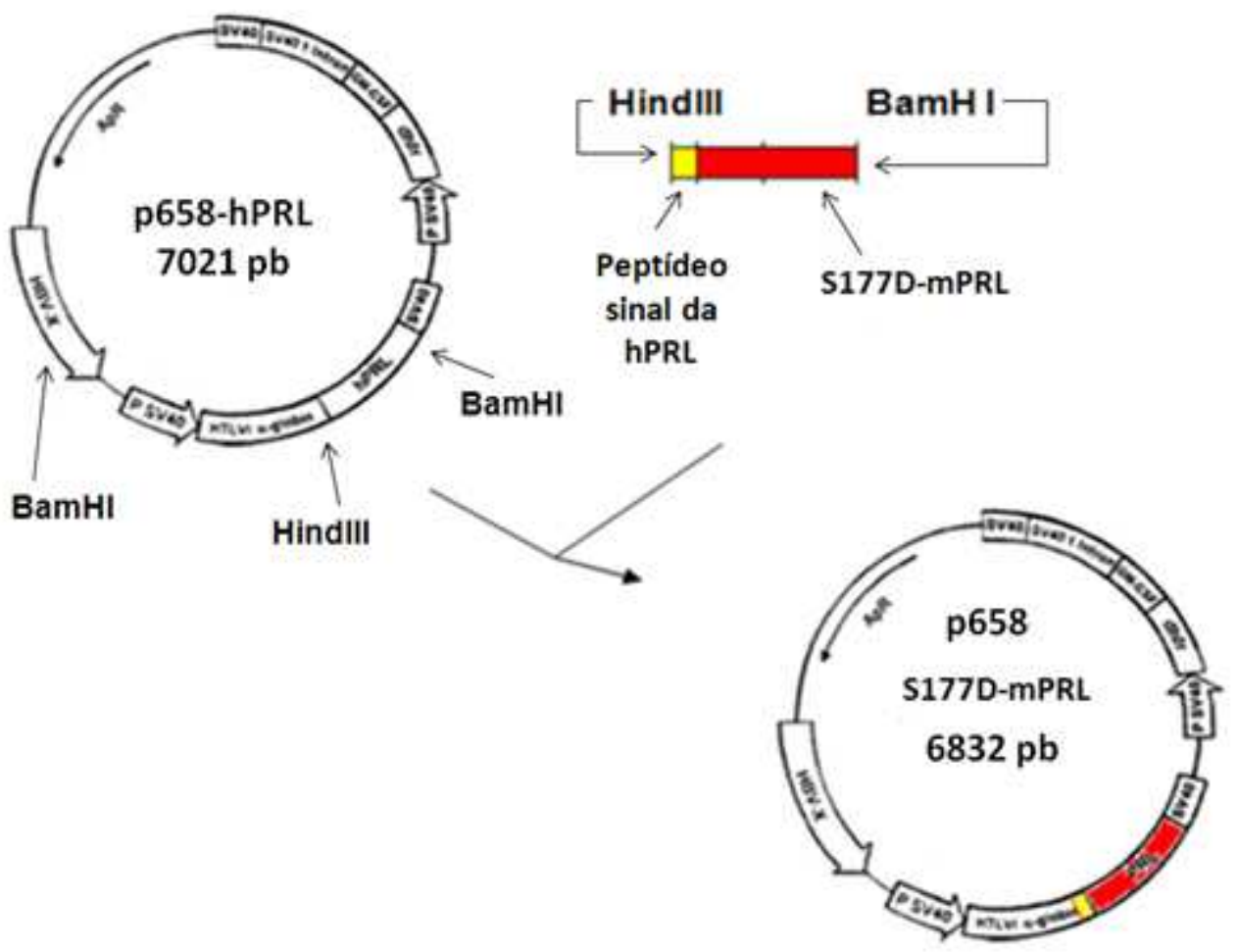

FIGURA 4. Esquema de construção do vetor p658-S177D-mPRL para células de mamíferos $\mathrm{CHO}$ dhfr para expressão do antagonista, por substituição da sequência correspondente à prolactina humana (hPRL). 


\subsubsection{Construção do vetor pEDdc-S177D-mPRL}

O plasmídeo pEDdc foi gentilmente doado pelo Dr. Wood (Genetics Institute, Cambridge, MA, EUA). O gene correspondente ao S177D-mPRL foi retirado do pUC57-S177D-mPRL pela digestão com a enzima Xbal. O vetor pEDdc-S177D-mPRL foi obtido em nosso laboratório pela inserção do gene do antagonista de $\mathrm{mPRL}$ no único sítio Xbal presente no pEDdc previamente desfosforilado com a enzima CIAP (FIG. 5). Para verificar se o inserto estava na orientação correta, o plasmídeo foi digerido com a enzima EcoRI e Xbal. Quando na orientação correta, a digestão resulta em fragmento com 495 pb, por outro lado, se o fragmento estiver inserido no sentido inverso, o fragmento apresenta $263 \mathrm{pb}$. A principal dificuldade encontrada nessa construção foi obter o vetor $100 \%$ linearizado e com uma desfosforilação eficiente, sem o comprometimento da reação de ligação com o inserto. Nesse caso o controle, que consiste na reação de ligação só com o vetor aberto, deve apresentar, após a reação de transformação, um número bem menor de clones com relação à reação principal, que contém também o inserto.

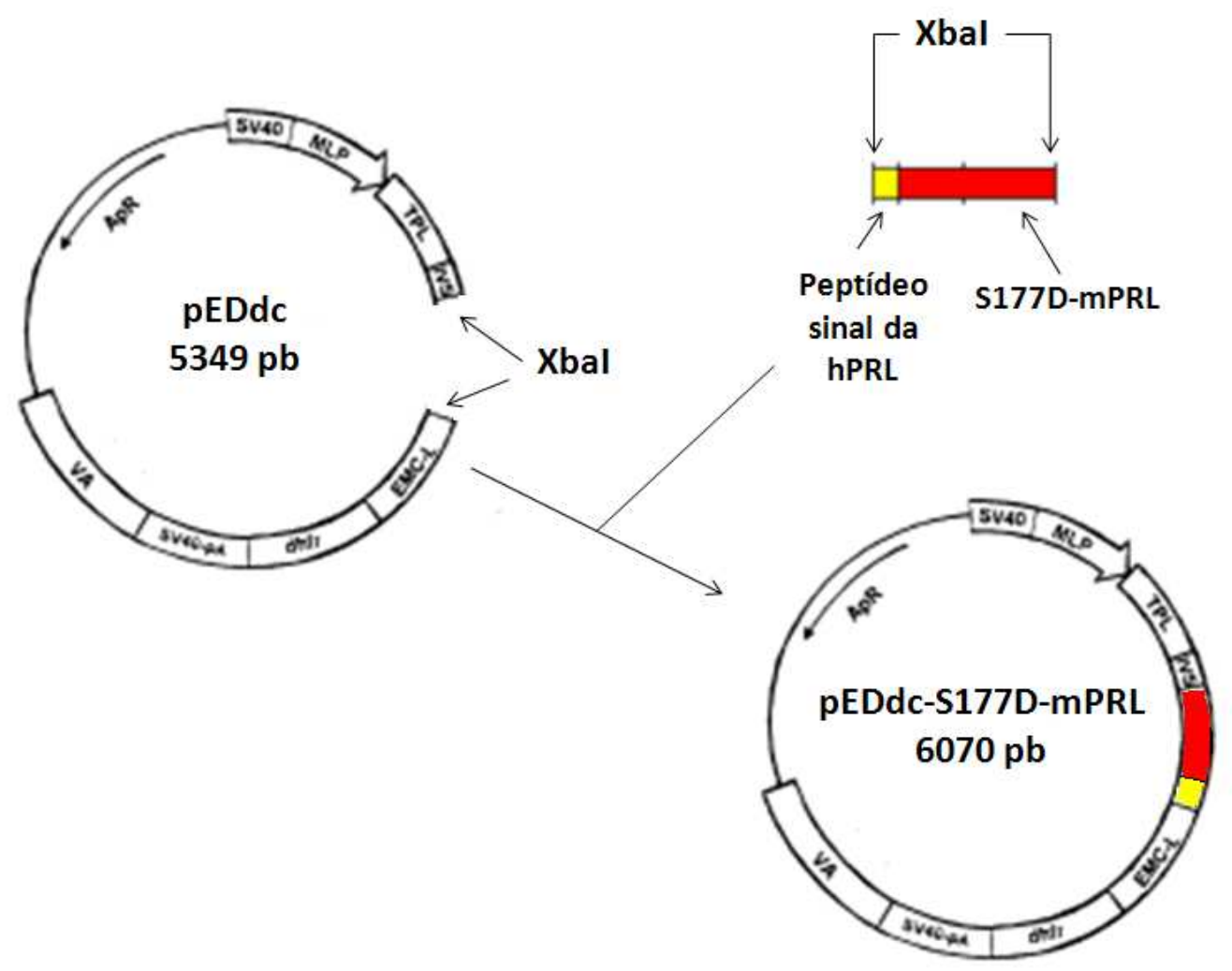

FIGURA 5. Esquema de construção do vetor pEDdc-S177D-mPRL para expressão do antagonista em células $\mathrm{CHO}$ dhfr'. 


\subsection{Transformação e expressão em Escherichia coli}

Para a expressão da mPRL e do S177D-mPRL no periplasma bacteriano foram utilizadas as cepas de E. coli W3110, RB791 e Rosetta-gami-B®, transformadas com os clones contendo o vetor de expressão $\lambda P_{L}-D s b A-m P R L$ ou $\lambda P_{L}$-DsbA-S177D-mPRL. Considerando resultados recém-obtidos, optamos por não utilizar o plasmídeo do repressor pRK248clts, cuja presença prejudicou a expressão da hPRL (Soares e col., 2008). O cultivo foi realizado em frascos com capacidade para $500 \mathrm{~mL}$ contendo $100 \mathrm{~mL}$ de meio LB com amplicilina 0,1 $\mathrm{mg} / \mathrm{mL}$, inoculando-se uma única colônia de $E$. coli obtida da placa de seleção e incubando a $30^{\circ} \mathrm{C}$ com agitação rotacional. Após o crescimento a $30^{\circ} \mathrm{C}$ até uma massa bacteriana correspondente a $1,5 \mathrm{~A}_{600}$, a temperatura foi elevada a $37^{\circ} \mathrm{C}$ por 6 horas. Foram selecionados os clones que apresentaram maior expressão na análise ou por cromatografia líquida de alto desempenho em fase reversa (RPHPLC) das amostras obtidas após o choque osmótico ou por análise de WB.

O fluido periplásmico dos diferentes clones foi obtido por meio de choque osmótico que consiste basicamente na incubação em meio hipertônico seguido de incubação em meio hipotônico. A sua finalidade é extrair as proteínas periplásmicas, sem que ocorra ruptura das células. Utilizamos o método de Koshland e Botstein, 1980, com modificações, como descrito por Soares e colaboradores (2003). Brevemente, terminada a fermentação, o meio é centrifugado a $4000 \mathrm{~g}$ por $10 \mathrm{~min}$ a $4^{\circ} \mathrm{C}$. O precipitado é ressuspenso em solução Tris- $\mathrm{HCl}(10 \mathrm{mM}, \mathrm{pH} 7,5)$, sacarose $20 \%$, acrescida de solução de EDTA 0,5 M pH 8,0 e mantido em repouso em banho de gelo por $10 \mathrm{~min}$. A suspensão é centrifugada novamente e o precipitado ressuspenso em solução de Tris- $\mathrm{HCl}$ (1 $\mathrm{mM}, \mathrm{pH} 7,0$ ) e mantido em banho de gelo por $10 \mathrm{~min}$. Após nova centrifugação, o sobrenadante contendo as proteínas periplásmicas é estocado a $-80^{\circ} \mathrm{C}$. $\mathrm{O}$ volume de Tris- $\mathrm{HCl}$ ou sacarose é calculado pela fórmula: $\mathrm{V}_{\mathrm{sac}}(\mathrm{mL})=\left(\mathrm{A}_{600 \mathrm{~nm}} \mathrm{X}\right.$ volume do meio $(\mathrm{mL})) / 100$ e o volume de EDTA pela fórmula: $V_{\text {EDTA }}(\mathrm{mL})=$ $\mathrm{V}_{\mathrm{sad}} / 30$. 


\subsection{Transfecção e expressão em células de mamíferos}

Os vetores p658-S177D-mPRL e pEDdc-S177D-mPRL foram amplificados em E. coli cepa $\mathrm{DH} 5 \alpha$ e purificados com Kits de Maxiprep obtendo a pureza necessária para as transfecções. A razão 260/280 nm inferior a 1,8 é considerado DNA puro e foi avaliado no equipamento NanoDrop® (modelo ND-1000, Wilmington, EUA) do Centro de Estudos do Genoma Humano - IBUSP. A transfecção para as células CHO-K1, CHO dhfr- (mutante DXB11) e COS-7 foi realizada utilizando Lipofectamine®.

As células $\mathrm{CHO}-\mathrm{K} 1$, COS-7 e CHO dhfr- (mutante DXB11) foram cultivadas em meio RPMI 1640, DMEM High Glucose e a-MEM, respectivamente. Foram adicionados ainda 10\% de SFB e antibióticos (penicilina, estreptomicina, anfotericina B e garamicina). Dois dias antes da transfecção, as células foram semeadas em placas de 24 poços na concentração de 50.000 células em $500 \mu \mathrm{L}$ de meio completo. A transfecção foi realizada com Lipofectamine $\AA^{\circ}$ seguindo 0 protocolo do fabricante. Em cada poço foram aplicados 500 ng de DNA (pEDdcS177D-mPRL ou p658-S177D-mPRL) e 1 a $3 \mu \mathrm{L}$ de Lipofectamine® em $400 \mu \mathrm{L}$ de meio, sem SFB e sem antibióticos. Após 5 horas da transfecção, foram adicionados $400 \mu \mathrm{L}$ de meio com $20 \%$ SFB e com antibióticos (totalizando 800 $\mu \mathrm{L}$ (poço). No dia seguinte o meio foi trocado e $48 \mathrm{~h}$ após, substituído por meio CHO-S-SFM II sem SFB com antibióticos. No dia seguinte (após 24h), o meio condicionado foi coletado e congelado.

Para a seleção de clones estáveis, as células CHO dhfr- (mutante DXB11) transfectadas com o plasmídeo p658-S177D-mPRL foram cultivadas em meio $\alpha$ MEM sem nucleosídeos, suplementado com 10\% de SFB dialisado. Foram selecionados 24 clones e a expressão em meio CHO-S-SFM II foi analisada por dot blot/WB.

No caso do plasmídeo pEDdc, para a obtenção de clone estável, as células CHO transfectadas foram cultivadas em meio a-MEM sem nucleosídeos, suplementado com 10\% de SFBd por 20 dias. Depois desse período, foi iniciada a amplificação gênica com metotrexato (MTX) nas concentrações crescentes de 10, 20 e 50 nM. Depois de atingida a confluência com 50 nM MTX em placa de 10 $\mathrm{cm} \varnothing$, o meio a-MEM foi substituído por meio CHO-S-SFM II sem SFB. Vinte e quatro horas depois, o meio foi coletado e a expressão de S177D-mPRL foi 
analisada por dot blot/WB. Até o presente momento, não foram selecionados clones, pois as etapas de amplificação até $10 \mu \mathrm{M}$ MTX ainda não foram concluídas.

\subsection{Caracterização físico-química}

A mPRL e o antagonista S177D-mPRL foram caracterizadas mediante técnicas físico-químicas como SDS-PAGE, dot blot, WB, RP-HPLC e HPSEC.

\subsubsection{Análise por SDS-PAGE, dot blot e Western Blotting}

Foram realizadas análises da $\mathrm{mPRL}$ e do S177D-mPRL mediante eletroforese em gel de poliacrilamida com dodecil sulfato de sódio (SDS-PAGE), em condições não-redutora e redutora com beta-mercaptoetanol (Laemmli, 1970; Maniatis e col., 1989). Para a revelação foi utilizado Coomassie Brilliant Blue G250 (Soares e col., 2000).

Em alguns casos, as proteínas do meio de cultura condicionado foram concentradas por precipitação com ácido tricloroacético (TCA) (Maniatis e col., 1989). Brevemente, o TCA foi adicionado ao meio na proporção de 1:4. A solução foi incubada por 10 min a $4^{\circ} \mathrm{C}$ e centrifugada (14.000 RPM, $5 \mathrm{~min}$ ). O "pellet" foi lavado com acetona gelada, seco em hot blot e ressuspenso no tampão apropriado para análises por WB. Quando aplicado o lisado celular, as células de mamíferos foram tripsinizadas, ressuspendidas em PBS na concentração de $10^{6}$ células $/ \mathrm{mL}$, adicionado tampão de amostra e fervidas por $10 \mathrm{~min}$. No caso do lisado de bactérias, foi ajustado para $A_{600}=1$ unidade em Tris- $\mathrm{HCl}(1 \mathrm{mM} \mathrm{pH} 7)$, adicionado tampão de amostra e fervidas por $10 \mathrm{~min}$.

Para a realização do WB, foi seguida basicamente a técnica de transferência semi-seca, utilizando-se o soro anti-prolactina de camundongo (NIH/NIDDK) produzido em coelho (1:25000, incubando overnight) e proteína $A$ marcada com ${ }^{125}$ I (meia-vida de 59,4 dias e emissor de raios gama de 35,5 keV) na atividade de $400000 \mathrm{CPM} / \mathrm{mL}$, incubando por uma hora. Após as lavagens, a membrana foi exposta ao filme overnight.

Nos ensaios utilizando dot blot, as amostras foram transferidas por gravidade para membranas de nitrocelulose e incubadas com o mesmo soro antiprolactina de camundongo (NIH/NIDDK) produzido em coelho (1:25000, 
incubando overnight) e anticorpo secundário anti-lgG de coelho (1:1000, incubando por uma hora). A revelação foi feita por quimioluminescência com peroxidase e luminol (1:1), incubando por 5 min (Immobilion ${ }^{\mathrm{TM}}$ ) e exposto ao filme por 30 segundos.

\subsubsection{Cromatografia líquida de alto desempenho em fase reversa (RP- HPLC)}

Foi utilizado o sistema de HPLC da marca Shimadzu Modelo SCL-10 A, acoplado a um detector de UV SPD-10 AV (Shimadzu, MD, EUA), usando o software Class VP, também da Shimadzu e uma coluna C4 Vydac 214TP54 (25 $\mathrm{cm} \times 4,6$ mm ID, diâmetro dos poros de $300 \AA$ e diâmetro das partículas de $5 \mu \mathrm{m}$ ). Para a proteção da coluna principal, uma coluna de sílica empacotada com LiChrosorb Si-60, 7,9-12,4 $\mu$ m (Merck, Darmstadt, Alemanha) foi instalada entre a bomba e o injetor. A fase móvel consistiu em tampão Tris-HCl 71\% $(50 \mathrm{mM}, \mathrm{pH}$ 7,5 ) e n-propanol 29\% (Dalmora e col., 1997). O fluxo foi de $0,5 \mathrm{~mL} / \mathrm{min}$, com leitura do detector no comprimento de onda de $220 \mathrm{~nm}$. A temperatura da coluna foi mantida a $45^{\circ} \mathrm{C}$ e o volume máximo da amostra de $500 \mu \mathrm{L}$ (Soares e col., 2000; Soares e col., 2003).

\subsubsection{Cromatografia líquida de alto desempenho por exclusão molecular (HPSEC)}

Foi utilizada uma coluna de aço inoxidável TSK G2000 SW, $60 \mathrm{~cm} \times 7,5$ mm I.D., com tamanho das partículas de $10 \mu \mathrm{m}$ e tamanho dos poros de $125 \AA$ (TosoHaas, Montgomeryville, PA, EUA) acoplada a uma pré-coluna TSK SW de $7,5 \mathrm{~cm} \times 7,5 \mathrm{~mm}$ I.D., sendo a fase móvel constituída de bicarbonato de amônio $0,025 \mathrm{M}, \mathrm{pH} 7,0$ ajustado com ácido fosfórico $2 \%$. O fluxo foi de $1 \mathrm{~mL} / \mathrm{min}$ (Dalmora e col., 1997) e comprimento de onda de $220 \mathrm{~nm}$.

\subsection{Cultivo em biorreator da linhagem transformada de W3110 Escherichia coli}

Os experimentos no biorreator (Laboratory Bioreactor - New MBR, Zurique, Suiça) com capacidade para $20 \mathrm{~L}$ de meio foram realizados em $\mathrm{pH} 7,2$ e $\mathrm{O}_{2}$ 
dissolvido mantido a $20 \%$ de saturação com velocidade de agitação entre 200 e 900 rpm. Foram utilizados $5 \mathrm{~L}$ de meio de cultura complexo, duas vezes mais concentrado que o meio HKSII (Jensen e Carlsen, 1990) com 0,1 mg/mL de ampicilina. Para o inóculo foram utilizados $500 \mathrm{~mL}$ de meio LB com ampicilina (10\% do volume inicial total) com $\mathrm{A}_{600}$ de $\sim 0,5$, mantendo-se a cultura a $30^{\circ} \mathrm{C}$ até a ativação. Quando a biomassa atingiu 5 unidades $A_{600}$, uma solução de glicose dissolvida no meio HKSII foi adicionada lentamente, $1,1 \mu \mathrm{g} / \mathrm{mL} / \mathrm{h}$ (feed batch). A elevação da temperatura para $37^{\circ} \mathrm{C}$ foi efetuada quando foi atingido um platô (Soares e col., 2008).

\subsection{Purificação}

Foi estabelecido um novo processo de purificação dividido em três etapas: concentração e purificação em coluna Phenyl Sepharose CL 4B, seguida por RPHPLC e HPSEC com troca de tampão (diálise). A amostra obtida do choque osmótico foi ajustada com acetato de amônio para osmolaridade inicial de 0,4 M, aplicada na coluna Phenyl Sepharose CL-4B, eluída em 0,01 M de acetato de amônio e 0,3 $\mathrm{mM}$ de tampão fosfato de sódio. O produto coletado foi analisado em RP-HPLC em tampão fosfato de sódio 0,05 M e acetonitrila 43\% e 50\%, pH $7,0,30^{\circ}$ C. As frações coletas do pico na RP-HPLC foram aplicadas na coluna de HPSEC em tampão fosfato de sódio 0,05 M, pH 7,0. Foram coletadas as amostras correspondentes aos picos da HPSEC para análise por SDS-PAGE, WB e ensaio biológico.

\subsection{Ensaios biológicos}

Os ensaios de proliferação foram realizados com as linhagens de células de linfoma de rato $\mathrm{Nb} 2$ e de células de camundongos pro-B Ba/F3-LLP, variandose a quantidade de $\mathrm{mPRL}$. Os ensaios foram realizados em triplicata ou quadruplicata e considerados os resultados de três ensaios independentes.

As células $\mathrm{Ba} / \mathrm{F3}$-LLP, transfectadas com o gene do receptor longo de $\mathrm{hPRL}$, foram mantidas rotineiramente em suspensão em meio RPMI 1640 suplementado com $10 \%$ de soro fetal bovino (SFB) inativado por aquecimento (20 $\min$ a $\left.45^{\circ} \mathrm{C}\right), 2 \mathrm{mM}$ de glutamina, $50 \mathrm{U} / \mathrm{mL}$ de penicilina, $50 \mu \mathrm{g} / \mathrm{mL}$ de 
estreptomicina, $700 \mu \mathrm{g} / \mathrm{mL}$ de geneticina (G418) e $1 \mathrm{ng} / \mathrm{mL}$ de $\mathrm{hPRL}$ recombinante $(\mathrm{r}-\mathrm{hPRL})$. Antes de começar o ensaio de proliferação, as células foram mantidas em meio sem prolactina e com 1\% de SFB inativado, por 4 a $6 \mathrm{~h}$, depois distribuídas em placa de 96 poços (50 × 10 4 células/poço) com um volume final de $200 \mu \mathrm{L}$ por poço, incluído a amostra. Depois de $72 \mathrm{~h}$ de incubação a $37^{\circ} \mathrm{C}$ e $5 \%$ de $\mathrm{CO}_{2}$, o número de células viáveis foi avaliado por coloração com MTS (Chen e col., 1998). Brevemente, 2 mg/mL de MTS [3(4,5-dimetiltiazol-2-il)-5(3carboximetoxifenil)-2-(4-sulfofenil)-2H-tetrazolina (Promega Corp., Madison, WI, USA)] dissolvidos em solução fosfato-salina (PBS) foi misturado na proporção de 20:1 (v/v) com metossulfato de fenazina (Sigma, Saint Louis, MO, USA), 0,92 $\mathrm{mg} / \mathrm{mL}$ em PBS. Vinte microlitros da mistura foram adicionados a cada poço e após 2 h de incubação a 37ํㅡ $\mathrm{C}$ a absorvância foi lida no comprimento de onda de $490 \mathrm{~nm}$ utilizando-se um leitor de microplacas.

As células de linfoma de rato Nb2 que possuem o receptor longo mutado foram mantidas rotineiramente em meio RPMI 1640 suplementado com 10\% de soro fetal bovino (SFB), 10\% de soro de cavalo castrado (SCC), penicilina (50 $\mathrm{U} / \mathrm{mL}$ ), e beta mercaptoetanol $5 \mathrm{mM}$ (1:50) em solução salina. Antes de começar o ensaio de proliferação, as células foram mantidas em meio com 1\% de SFB por $12 \mathrm{~h}$, constituindo o pré-ensaio. Depois desse período, o meio foi centrifugado e as células foram ressuspensas no meio de ensaio, em que não há a presença de SFB e foram, então, distribuídas em placa de 96 poços $\left(50 \times 10^{4}\right.$ células/poço $)$ com um volume final de $200 \mu \mathrm{L}$ por poço, incluindo a amostra. Depois de $72 \mathrm{~h}$ de incubação a $37^{\circ} \mathrm{C}$ e $5 \%$ de $\mathrm{CO}_{2}$, o número de células viáveis foi avaliado por coloração com MTS (Chen, 1998), da mesma forma que as células pro-B Ba/F3LLP. 


\section{RESULTADOS}

\subsection{Caracterização do padrão de r-met-mPRL (NIH/NIDDK)}

O padrão de mPRL recombinante (AFP405C) para estudos biológicos foi obtido do National Institute of Health/National Institute of Diabetes \& Digestive \& Kidney Diseases (NIH/NIDDK), Torrance - CA - EUA. Por ser produzido em corpos de inclusão apresenta uma metionina na porção N-terminal, 198 aminoácidos e peso molecular de $22553 \mathrm{Da}$. O produto liofilizado $(\sim 1 \mathrm{mg})$ foi dissolvido em $5 \mathrm{~mL}$ de $0,01 \mathrm{M} \mathrm{NaHCO}_{3}$, fracionado em tubos em alíquotas de 100 $\mu \mathrm{L}$ e congelado a - 80ํ C. Esse padrão apresenta ácido aspártico na posição 176 (Sinha, 1995; Watahiki e col., 1989; Kohmoto e col., 1984), embora existam relatos na literatura que descrevem uma histidina nessa mesma posição (Harigaya e col., 1986). A caracterização é essencial para determinação da identidade e quantificação por HPLC, do padrão de migração e da massa molecular por SDS-PAGE, da atividade imunológica por WB e da atividade biológica por ensaio de proliferação.

\subsubsection{Análise por HPLC}

Nos estudos para o estabelecimento dos tempos de retenção em HPLC de fase reversa (RP-HPLC) foram analisados os padrões de r-met-mPRL (NIH/NIDDK), r-hPRL (E. coli, padrão de referência interno, preparação P35) e do r-hGH, padrão internacional da Organização Mundial da Saúde (OMS). Um parâmetro importante como controle de identidade no caso da HPLC de fase reversa é o "tempo de retenção relativo" ( $\left.\mathrm{t}_{\mathrm{RR}}\right)$. Esse parâmetro avalia a relação entre o tempo de retenção $\left(t_{R}\right)$ da amostra analisada e o $t_{R}$ de uma amostra de referência. Uma alteração no $\left(t_{R R}\right)$ indica uma mudança de hidrofobicidade da amostra, sendo que este parâmetro é independente das condições de cromatografia. Observamos na análise em RP-HPLC que a hidrofobicidade da $r$ met-mPRL (NIH/NIDDK) é menor em relação aos outros hormônios (TAB. $1 \mathrm{e}$ FIG. 6). Adotando-se a $h P R L$ como referência, o $t_{R R}$ da $m P R L=0,8$; enquanto o hGH apresenta $t_{R R}=1,3$ (TAB. 1). 
TABELA 1. Tempos de retenção absolutos $\left(t_{R}\right)$ observados na análise em RPHPLC dos hormônios r-hPRL (E. coli, padrão interno P35), r-met-mPRL (NIH/NIDDK) e r-hGH (padrão internacional da OMS) $(n=5)$.

\begin{tabular}{|c|c|c|c|c|c|}
\hline Hormônio & Média \pm DP (\%CV) & $\begin{array}{c}t_{R R} \\
(r-h P R L)\end{array}$ & $\begin{array}{c}\text { Área (u. a.) } \\
\text { Média } \pm \text { DP (\%CV) }\end{array}$ & $\begin{array}{c}\text { Massa } \\
(\mu \mathrm{g})\end{array}$ & $\begin{array}{c}\text { Absorvância } \\
\text { específica } \\
\text { (u. a./pg) }\end{array}$ \\
\hline r-met-mPRL & $21,53 \pm 2,80(13)$ & 0,8 & $2933 \pm 322(11)$ & 2 & 1466 \\
\hline r-hPRL & $25,79 \pm 2,23(9)$ & 1,0 & $9178 \pm 777(8)$ & 7 & 1311 \\
\hline r-hGH & $33,65 \pm 3,27(10)$ & 1,3 & $14034 \pm 1359(10)$ & 10 & 1403 \\
\hline
\end{tabular}

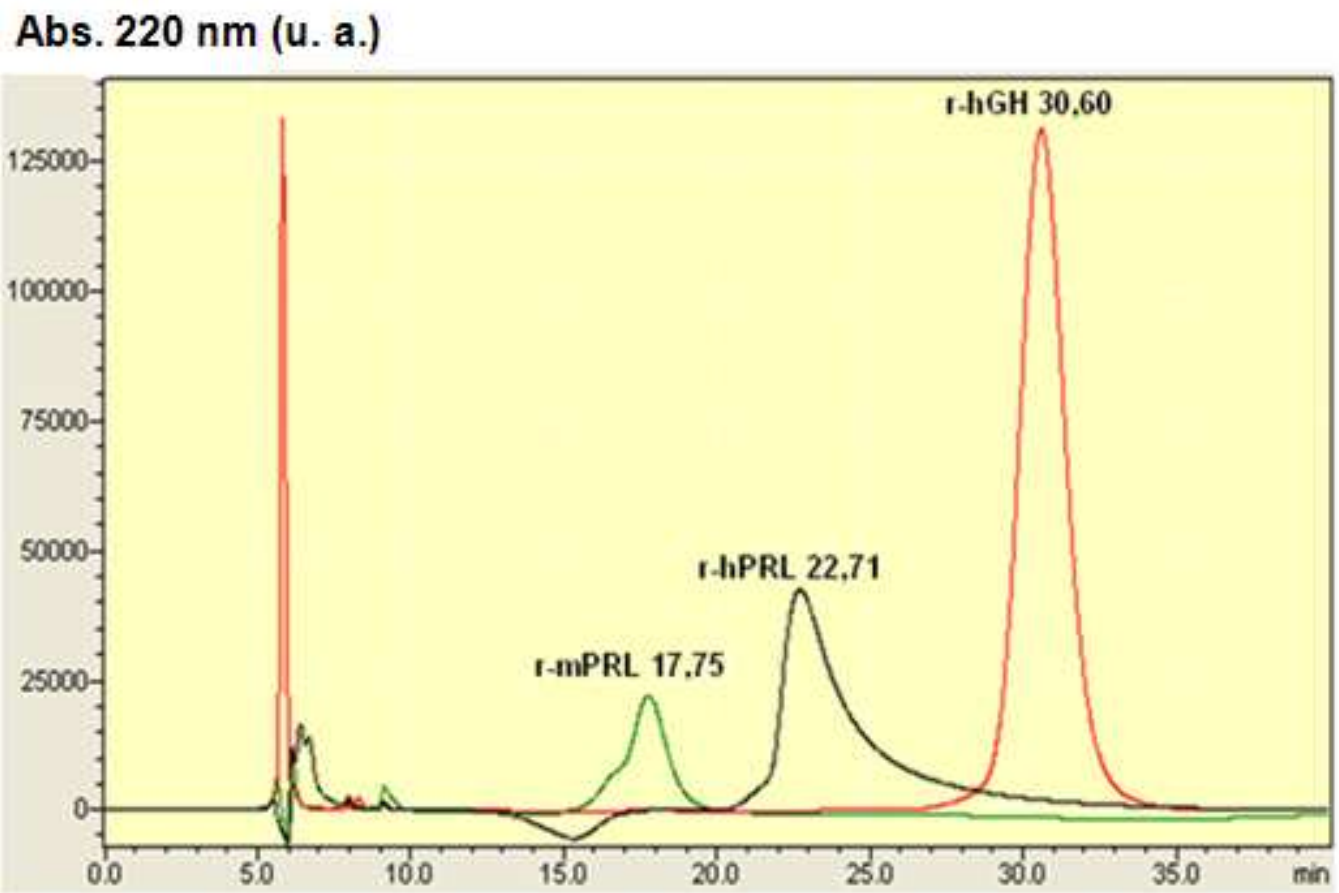

FIGURA 6. Cromatograma da análise em RP-HPLC da r-met-mPRL (NIH/NIDDK) $2 \mu \mathrm{g}$; da r-hPRL (padrão interno P35) $7 \mu \mathrm{g}$; e do r-hGH (Padrão Internacional da OMS) $10 \mu \mathrm{g}$. Foi utilizado como fase móvel Tris-HCl e n-propanol.

Podemos observar a grande diferença em hidrofobicidade ( 8 $\mathrm{min}$ ) existente entre a r-hPRL e o r-hGH e também entre a r-met-mPRL e a r-hPRL $(\sim 5$ min). Vale também ressaltar a relativa uniformidade em absorvância específica

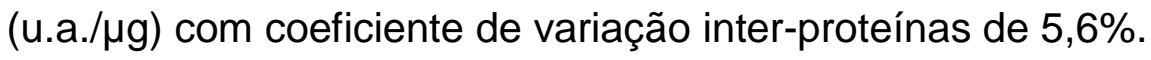


Já na análise em HPSEC, o tempo de retenção da r-hPRL (padrão interno P35) foi maior em comparação com a r-met-mPRL (TAB. 2 e FIG. 7). Não é esperado que a diferença de um aminoácido, como ocorre entre a r-hPRL (199 aa) e a r-met-mPRL (198 aa), tenham tanta influência no tempo de retenção por exclusão molecular que, inclusive, deveria ser maior para a proteína de massa molecular menor. A diferença observada no $t_{R}$ pode ser devida à conformação da r-met-mPRL, que de alguma forma, colabora para que sua eluição seja mais rápida que a da r-hPRL, devido a diferentes propriedades hidrodinâmicas.

TABELA 2. Tempos de retenção absolutos $\left(t_{R}\right)$ e relativos $\left(t_{R R}\right)$ observados na análise em HPSEC dos hormônios r-hPRL (padrão interno P35 - 22898 Da, 199 aa) e r-met-mPRL (NIH/NIDDK - $22553 \mathrm{Da}, 198 \mathrm{aa})(\mathrm{n}=5)$.

\begin{tabular}{|c|c|c|c|c|c|}
\hline Hormônio & $\begin{array}{c}t_{R}(\min ) \\
\text { Média } \pm \mathrm{DP}(\% \mathrm{CV})\end{array}$ & $\begin{array}{c}t_{\mathrm{RR}} \\
(\mathrm{r}-\mathrm{hPRL})\end{array}$ & $\begin{array}{c}\text { Área (u. a.) } \\
\text { Média } \pm \text { DP (\%CV) }\end{array}$ & $\begin{array}{c}\text { Massa } \\
(\mu \mathrm{g})\end{array}$ & 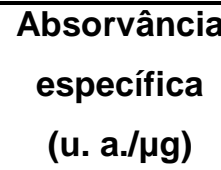 \\
\hline r-hPRL & $17,55 \pm 0,74(4,2)$ & 1,0 & $2373 \pm 160(6,8)$ & 7 & 339 \\
\hline r-met-mPRL & $14,96 \pm 0,25(1,7)$ & 0,9 & $1074 \pm 69(6,4)$ & 3 & 358 \\
\hline
\end{tabular}

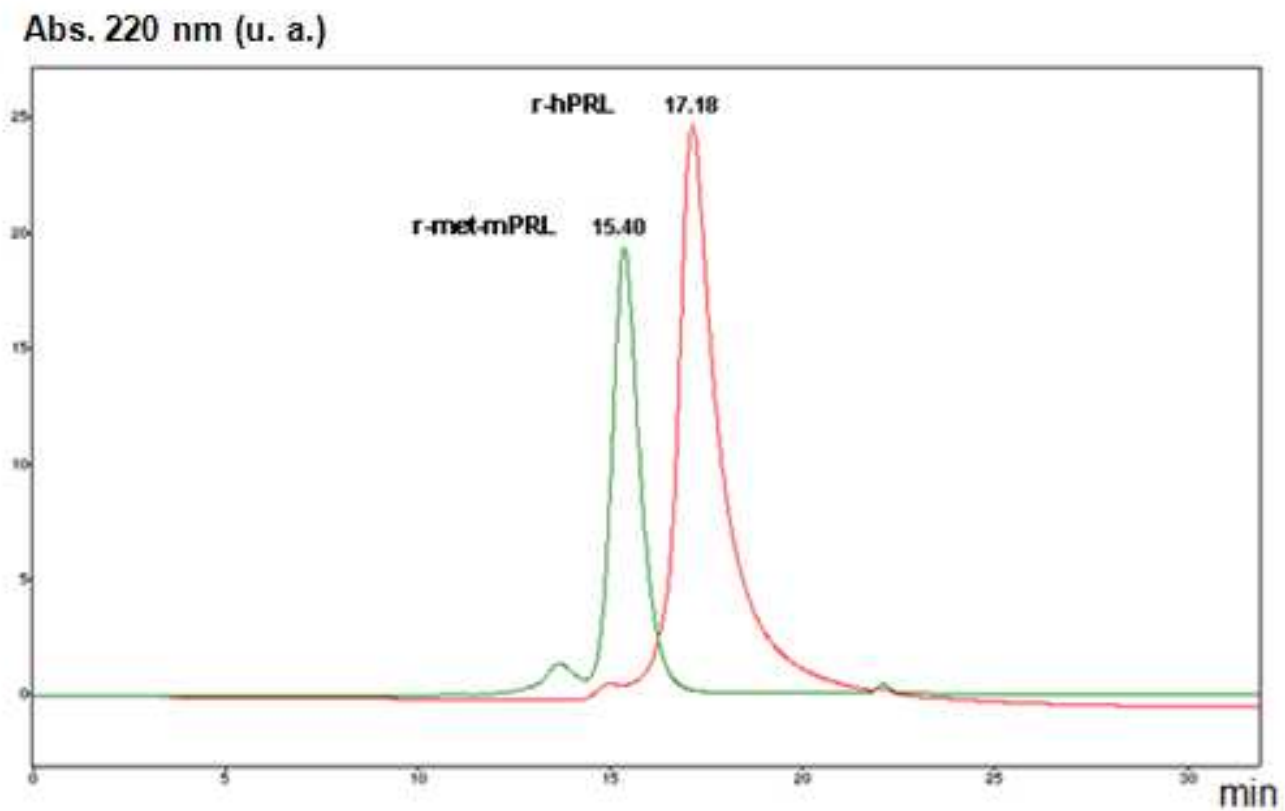

FIGURA 7. Cromatograma comparativo da análise por HPSEC da solução padrão de r-met-mPRL (NIH/NIDDK - 22553 Da, 198 aa) e de hPRL (padrão interno P35 - 22898 Da, 199 aa). Foi utilizado como fase móvel bicarbonato de amônio $0,025 \mathrm{M}, \mathrm{pH} 7,0$. 
A quantificação da solução padrão de r-met-mPRL da NIH/NIDDK foi realizada com base nas áreas obtidas por HPSEC em comparação com a r-hPRL. O valor calculado foi de 158,0 $\pm 9,3 \% \mu \mathrm{g} / \mathrm{mL}(\mathrm{n}=4)$, abaixo dos $200 \mu \mathrm{g} / \mathrm{mL}$ declarado. O valor da absorvância específica (u.a.//g) apresentou um coeficiente de variação inter-proteínas de 3,9\%.

\subsubsection{Análise por SDS-PAGE e Western Blotting da mPRL}

O SDS-PAGE e o WB mostraram que a r-met-mPRL aparece em posição inferior ao da r-hPRL (FIG. 8). Este comportamento é esperado, pois moléculas de menor massa migram para posições inferiores no gel. Observamos também no WB a especificidade do soro anti-mPRL que apresentou uma afinidade relativamente baixa contra a $\mathrm{hPRL}$, em comparação à $\mathrm{mPRL}$.

Como já mencionado a r-met-mPRL é composta por 198 aminoácidos (22553 Da) contra os 199 da r-hPRL (22898 Da). Técnicas como HPSEC ou SDSPAGE normalmente não conseguem detectar essa diferença de massa molecular apesar do fato que desta vez a molécula de menor massa migrou mais rapidamente na matriz.

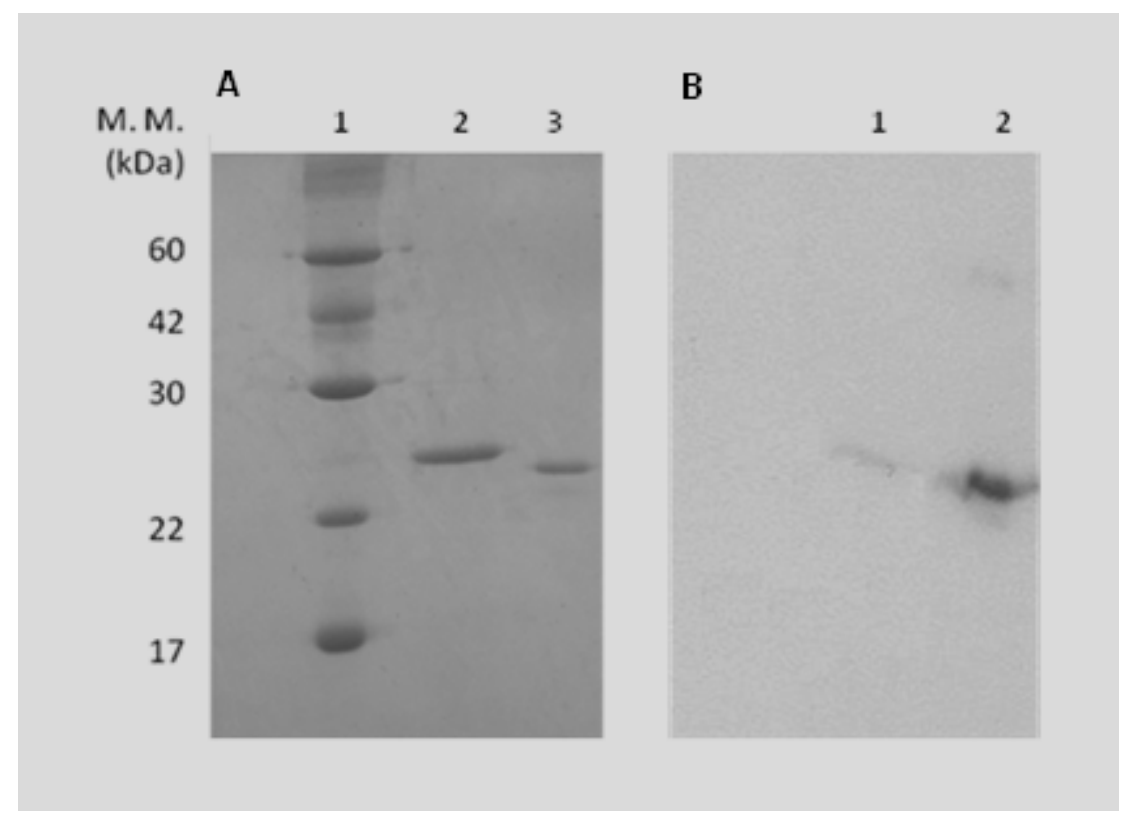

FIGURA 8. SDS-PAGE (em condição não-redutora) e WB da r-met-mPRL e rhPRL. (A) SDS-PAGE. (1) Marcador de massa molecular, (2) r-hPRL 560 ng, (3) r-met-mPRL 270 ng. (B) WB com soro anti-mPRL. (1) r-hPRL 56 ng, (2) r-metmPRL $27 \mathrm{ng}$. 


\subsubsection{Avaliação da atividade biológica da r-met-mPRL}

$\mathrm{O}$ bioensaio de proliferação com as células $\mathrm{Ba} / \mathrm{F} 3-\mathrm{LLP}$ foi realizado com 0 padrão de r-met-mPRL (NIH/NIDDK) e o primeiro padrão de hPRL recombinante da WHO 97/714 com potência declarada de 57,2 \pm 11,4 UI/mg (FIG. 9). A potência da r-met-mPRL utilizando as células Ba/F3-LLP foi de apenas 2,42 \pm $0,38 \mathrm{Ul} / \mathrm{mg}(\mathrm{n}=3)$. Essa baixa potência se justifica porque essas células de camundongo pro-B Ba/F3-LLP foram transfectadas com receptores para $\mathrm{hPRL}$, que possuem uma afinidade bem menor para a $\mathrm{mPRL}$. O mesmo comportamento já foi relatado por outros autores com células de camundongo pró-mieloide 32D também transfectadas com receptores de hPRL (Utama e col., 2006; 2009).

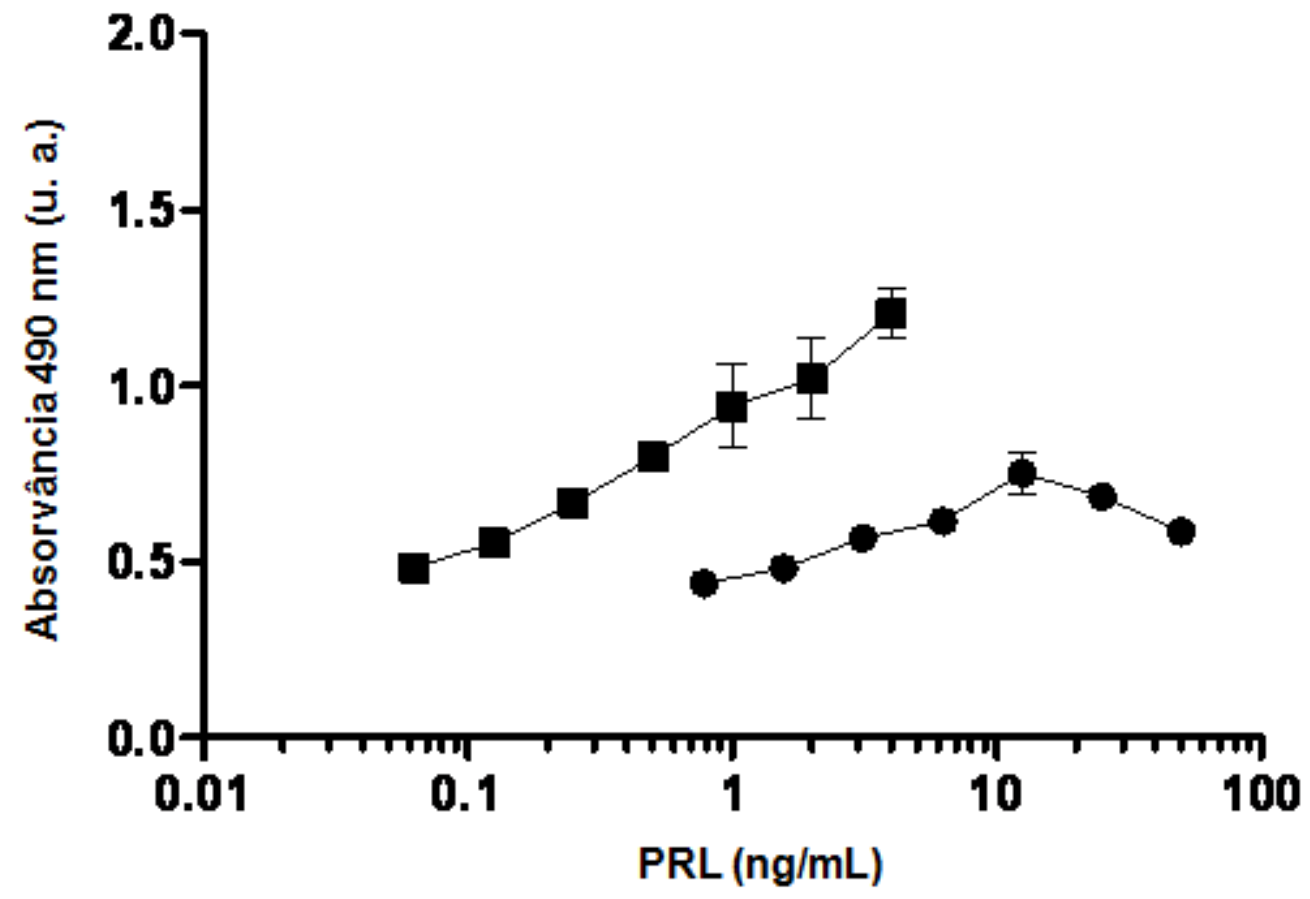

FIGURA 9. Ensaio de proliferação utilizando as células Ba/F3-LLP cultivadas na

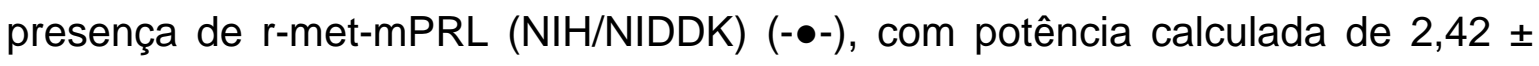
0,38 Ul/mg e de r-hPRL (WHO 97/714) (--a-), cuja potência declarada é de 57,2 \pm $11,4 \mathrm{UI} / \mathrm{mg}$. Cada ponto da curva foi obtido com amostras em triplicatas. 
Realizamos também o bioensaio clássico para avaliar a atividade lactogênica, utilizando as células pré-T de linfoma de rato $\mathrm{Nb}_{2}$, que apresentam receptores para prolactina de rato, ensaio mais apropriado para avaliarmos a potência da r-met-mPRL (FIG. 10). A potência foi calculada em 20,4 $\pm 2,1 \mathrm{UI} / \mathrm{mg}$ $(\mathrm{n}=4)$, também com base na atividade proliferativa da $\mathrm{hPRL}$ recombinante da WHO 97/714.

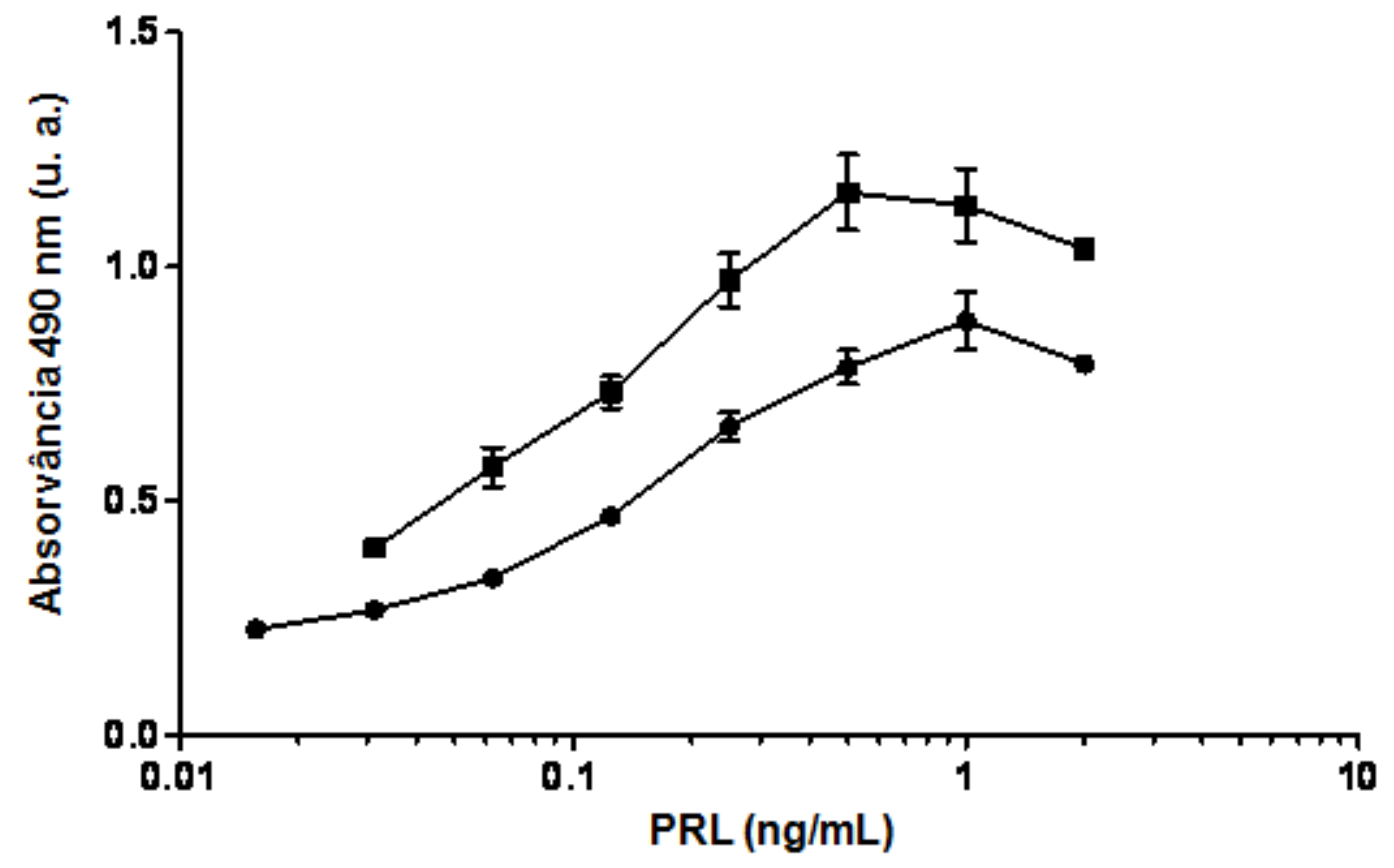

FIGURA 10. Exemplo de curvas dose-resposta com células Nb2 cultivadas na

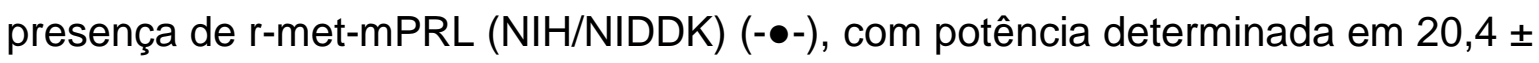
2,1 Ul/mg e de r-hPRL (WHO 97/714 ) (-ם-), cuja potência declarada é de 57,2 \pm $11,4 \mathrm{UI} / \mathrm{mg}$. Cada ponto da curva foi obtido com amostras em quadruplicatas. 


\subsection{Construção dos vetores bacterianos para a expressão da $m P R L$ e de seu análogo/antagonista (S177D-mPRL)}

Conforme mencionado em Materiais e Métodos, o vetor $\lambda P_{L}-D s b A-m P R L ~ e$ o vetor com a sequência gênica que codifica o antagonista, $\lambda P_{L}$-DsbA-S177DmPRL, ambos contendo o peptídeo sinalizador bacteriano DsbA, foram obtidos substituindo o gene do hGH presente no plasmídeo $\lambda \mathrm{P}_{\mathrm{L}}$-DsbA-hGH (Soares e col., 2003) pelo cDNA da mPRL, ou do S177D-mPRL obtidos do vetor pUC57 (FIG. 11B). As construções foram confirmadas por análise de restrição e seqüenciamento do DNA dos genes de interesse (FIG. 11A).

\subsubsection{Análise com enzimas de restrição}

A cepa DH5a foi transformada com os vetores de expressão, por eletroporação, para amplificação e análise de restrição.

Na FIG. 11 apresentamos um exemplo de análise de restrição em gel de agarose dos plasmídeos digeridos com as enzimas de restrição $\mathrm{Ndel}$, BamHI e EcoRI. Foi confirmado que o inserto de 719 pb entrou na posição planejada, ver mapa na FIG. 11B. Quando digerido somente com a enzima BamHI, observamos a linearização do plasmídeo e apenas uma banda com 3221 pb no gel de agarose (FIG. 11A, amostra 3). Já com as enzimas Ndel e BamHI, observamos duas bandas (FIG. 11A, amostra 4): a do vetor com 2567 pb e a do inserto com 719 pb. A sequência da $\mathrm{mPRL}$ (e do antagonista) apresenta um sítio EcoRI na posição 108, gerando, desta forma três fragmentos quando digerido com as enzimas de restrição BamHI e EcoRI: o do vetor com 2567 pb, um fragmento com 545 pb e outro com 174 pb (FIG. 11A, amostra 5). Análise similar foi realizada com 0 plasmídeo $\mathrm{p} \lambda \mathrm{P}_{\mathrm{L}}-\mathrm{DsbA}-\mathrm{S} 177 \mathrm{D}-\mathrm{mPRL}$, que também confirmou a construção correta. 
A

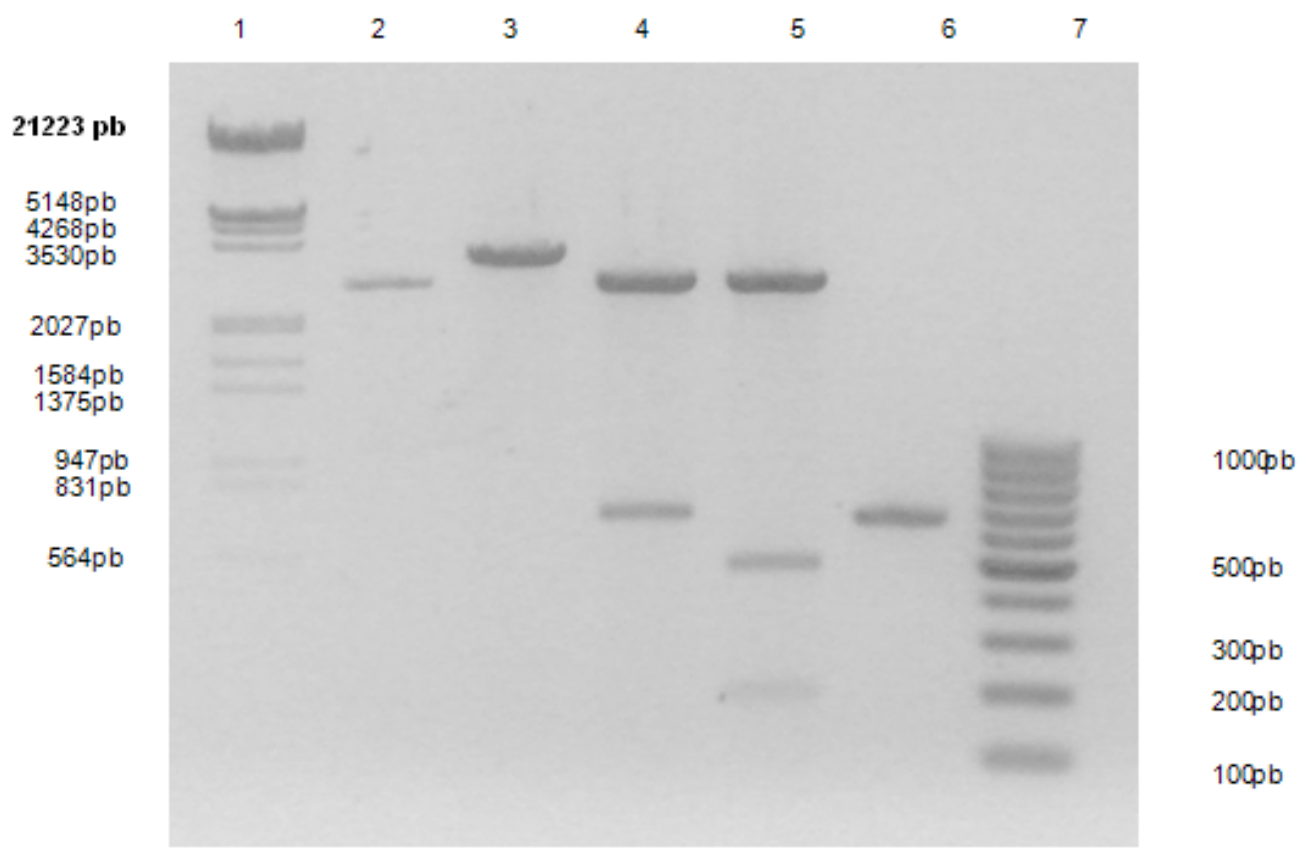

B

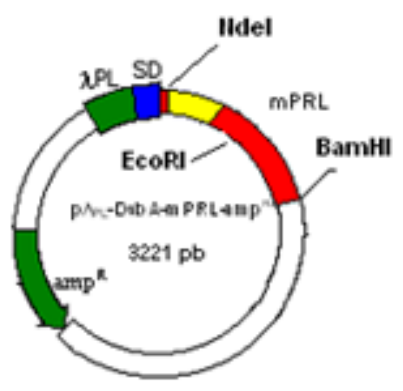

FIGURA 11

A. Eletroforese em gel de agarose 1\%, corado com brometo de etídio, exemplificando a análise de restrição para o $\mathrm{p} \lambda \mathrm{P}_{\mathrm{L}}$-DsbA-mPRL.

(1) Marcador de massa molecular em número de pares de bases (pb), Lambda DNA completamente digerido com EcoRI e Hindlll (500ng);

(2) Cassete de expressão, $110 \mathrm{ng}$ do vetor $\lambda \mathrm{P}_{\mathrm{L}}$ digerido com Ndel e BamHI, purificado e desfosforilado, fragmento com $2567 \mathrm{pb}$;

(3) Plasmídeo $\lambda P_{L}-D s b A-m P R L$ linearizado com a enzima BamHI, fragmento com $3221 \mathrm{pb}(240 \mathrm{ng})$;

(4) $\lambda P_{L}-D s b A-m P R L$ digerido com Ndel e BamHI, fragmentos com $2567 \mathrm{pb}$ e 719 $\mathrm{pb}$;

(5) $\lambda P_{L}-D s b A-m P R L$ digerido com EcoRI e BamHI, fragmentos com 2567 pb, 545 $\mathrm{pb}$ e $174 \mathrm{pb}$

(6) Inserto purificado do DNA correspondente ao DsbA-mPRL, fragmento com $719 \mathrm{pb}(260 \mathrm{ng})$

(7) Marcador de massa molecular em número de pares de bases (pb), "Gene ruler Ladder 100 pb" (500ng).

B. Mapa esquemático do vetor $\lambda$ PL-DsbA-mPRL. 


\subsubsection{Sequenciamento do cDNA correspondente à $M P R L$ e ao antagonista S177D-mPRL}

Para confirmar se a inserção no vetor das sequências relativas aos cDNA de $\mathrm{MPRL}$ e do antagonista sintetizadas pela Genscript estavam corretas, foram realizados seqüenciamentos de nucleosídeos. Inicialmente, confirmamos que a sequência sintetizada pela Genscript estava correta. Utilizamos os primers internos de mPRL, uma vez que os genes mPRL e S177D-mPRL estavam no plasmídeo comercial pUC57. Podem ser vistas as sequências TCC e GAC correspondentes aos aminoácidos serina e ácido aspártico, respectivamente. Os plasmídeos aprovados na análise por enzimas de restrição foram submetidos aos estudos de sequenciamento do cDNA utilizando os primers externos ao gene, já no vetor $\lambda P_{L}-D s b A$. Apresentamos parte do referido sequenciamento na FIG. 12. As diferenças na posição da trinca de bases da sequência A (641-643) e B (602604) são devidas a utilização de primers diferentes (primer $\mathbf{d}$ - forward e primer $\mathbf{e}$ reverse).

(A)

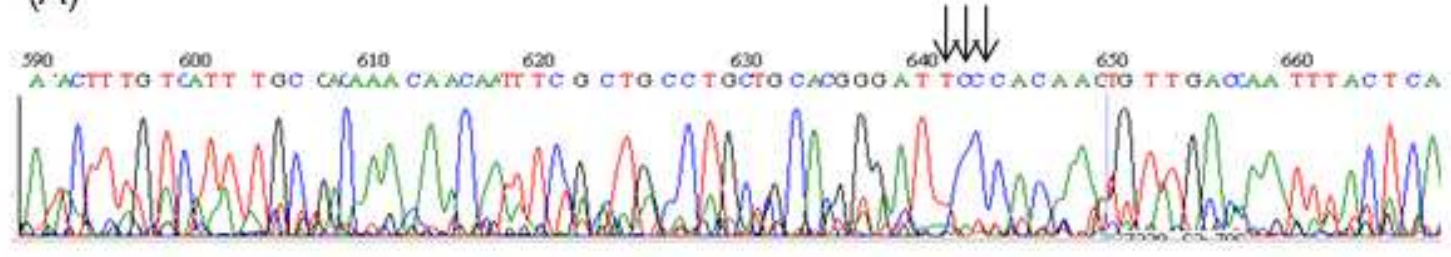

(B)

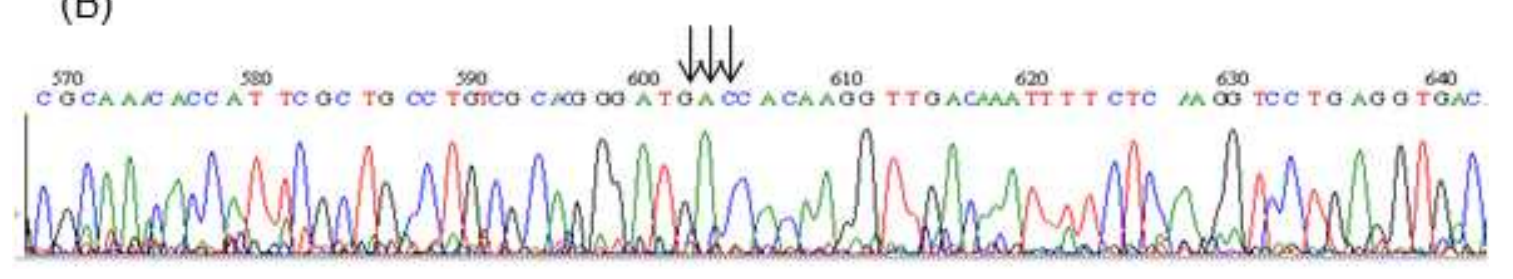

FIGURA 12. Parte do sequenciamento do cDNA dos vetores de expressão.

(A) Sequência gênica correspondente à $\mathrm{mPRL}$, as setas indicam a sequência TCC, correspondente ao aminoácido serina;

(B) Sequência gênica correspondente ao análogo S177D-mPRL, as setas indicam a sequência GAC, correspondente ao aminoácido ácido aspártico. 


\subsection{Transformação e expressão da mPRL e do seu análogo/antagonista} S177D mPRL

Confirmada a correta construção dos vetores $\lambda$ PL-DsbA-mPRL e $\lambda P L-$ DsbA-S177D-mPRL, os mesmos foram usados para transformar duas cepas de E. coli, a W3110 e a RB791, já utilizadas em nosso laboratório, e que apresentaram ótimos resultados de expressão. A eletroforese em gel de agarose $1 \%$, após digestão com as enzimas BamHI e Ndel (FIG. 13), confirmou que todos os clones analisados apresentaram o perfil esperado: a banda correspondente ao gene da mPRL ou S177D-mPRL com 719 pb e o vetor com 2567 pb.

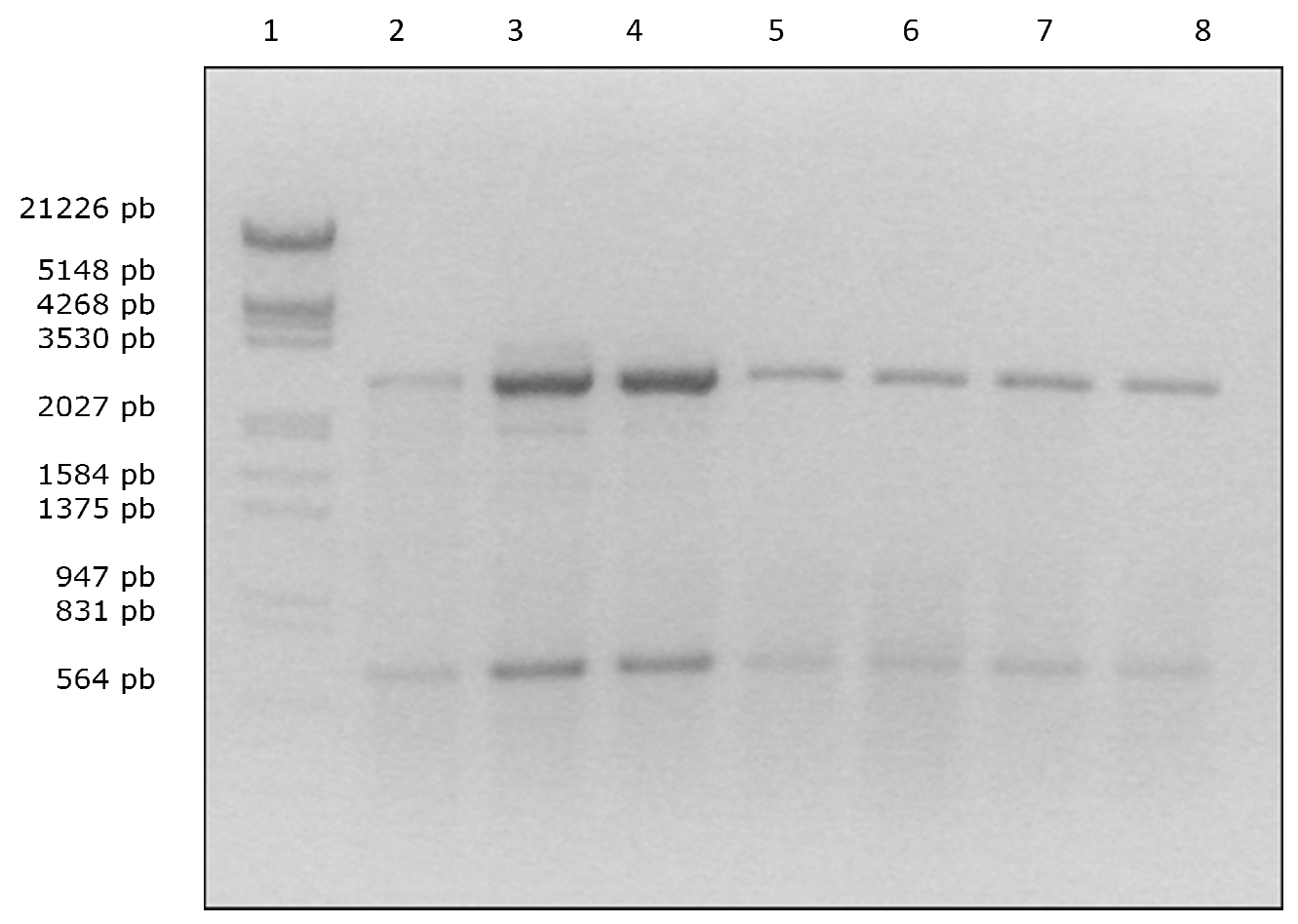

FIGURA 13. Eletroforese em gel de agarose 1\%, corado com brometo de etídeo, apresentando as bandas correspondentes aos plasmídeos digeridos com as enzimas de restrição BamHI e Ndel. (1) Marcador de massa molecular Lambda DNA/EcoRI + HindIII, Marker 3 (Fermentas), (2) W3110 mPRL clone 3, (3) W3110 S177D-mPRL clone 3, (4) W3110 S177D-mPRL clone 4, (5) RB791 mPRL clone 1, (6) RB791 mPRL clone 2, (7) RB791 mPRL clone 3, (8) RB791 mPRL clone 4. 
A expressão dos clones correspondentes à $\mathrm{mPRL}$ e ao S177D-mPRL determinada através das análises do fluido periplásmico obtido após fermentação em frascos. Os resultados das análises por RP-HPLC são apresentados na TAB. 3. O clone com maior nível de expressão foi escolhido para realização de novas fermentações em frascos para análise estatística da expressão. A expressão do análogo S177D-mPRL foi muito baixa, inferior ao limite de detecção pela nossa técnica por RP-HPLC.

TABELA 3. Expressão de mPRL e S177D-mPRL das cepas W3110 e RB791 após cultivo em frascos (100 mL de meio LB), choque osmótico e análise em RPHPLC (100 $\mu \mathrm{L})$. A produção foi calculada em função da área sob o pico e do tempo de retenção da r-hPRL recombinante usada como referência (P35).

\begin{tabular}{cccc}
\hline Clone & $\begin{array}{c}\text { W3110 } \mathbf{m P R L} \\
(\mu \mathrm{g} / \mathrm{mL} / \mathrm{DO})\end{array}$ & $\begin{array}{c}\text { W3110 S177D-mPRL } \\
(\mu \mathrm{g} / \mathrm{mL} / \mathrm{DO})\end{array}$ & $\begin{array}{c}\text { RB791 } \mathrm{mPRL} \\
(\mu \mathrm{g} / \mathrm{mL} / \mathrm{DO})\end{array}$ \\
\hline $\mathbf{2}$ & 0,098 & $\mathrm{ND}$ & $\mathrm{ND}$ \\
$\mathbf{3}$ & 0,074 & $\mathrm{ND}$ & $\mathrm{ND}$ \\
$\mathbf{4}$ & 0,076 & $\mathrm{ND}$ & \\
$\mathbf{5}$ & 0,002 & $\mathrm{ND}$ & \\
$\mathbf{6}$ & 0,059 & $\mathrm{ND}$ & \\
$\mathbf{7}$ & 0,075 & $\mathrm{ND}$ & \\
$\mathbf{8}$ & 0,006 & & \\
\hline
\end{tabular}

$\mathrm{ND}=$ não detectada por RP-HPLC

Os dados de expressão da $\mathrm{mPRL}$, inferiores a $0,1 \mu \mathrm{g} \mathrm{mPRL} / \mathrm{mL} / \mathrm{A}_{600}(\mathrm{TAB}$. 3), estão muito abaixo do obtido para hPRL 0,78 $\pm 16,4 \% \mu \mathrm{gPRL} / \mathrm{mL} / \mathrm{A}_{600}(\mathrm{n}=$ 3), realizado nas mesmas condições. A análise estatística de várias fermentações em frascos do clone 1 de W3110 mPRL confirmaram a expressão de 0,1 $\pm 13,2 \%$ $\mu \mathrm{g} \mathrm{mPRL} / \mathrm{mL} / \mathrm{A}_{600}(\mathrm{n}=5)$. 
Na FIG. 14 apresentamos exemplos de cromatogramas obtidos em RPHPLC para os padrões de r-hPRL e r-met-mPRL e também para os fluidos periplásmicos (choques osmóticos) dos clones produtores de mPRL e S177DmPRL. A diferença de $\sim 5$ minutos encontrada entre o padrão r-met-mPRL e a $\mathrm{mPRL}$ sintetizada em nosso laboratório é provavelmente devida à presença da metionina inicial. Podemos observar também que a expressão do S177D-mPRL foi extremamente baixa, inviabilizando sua produção em E. coli.
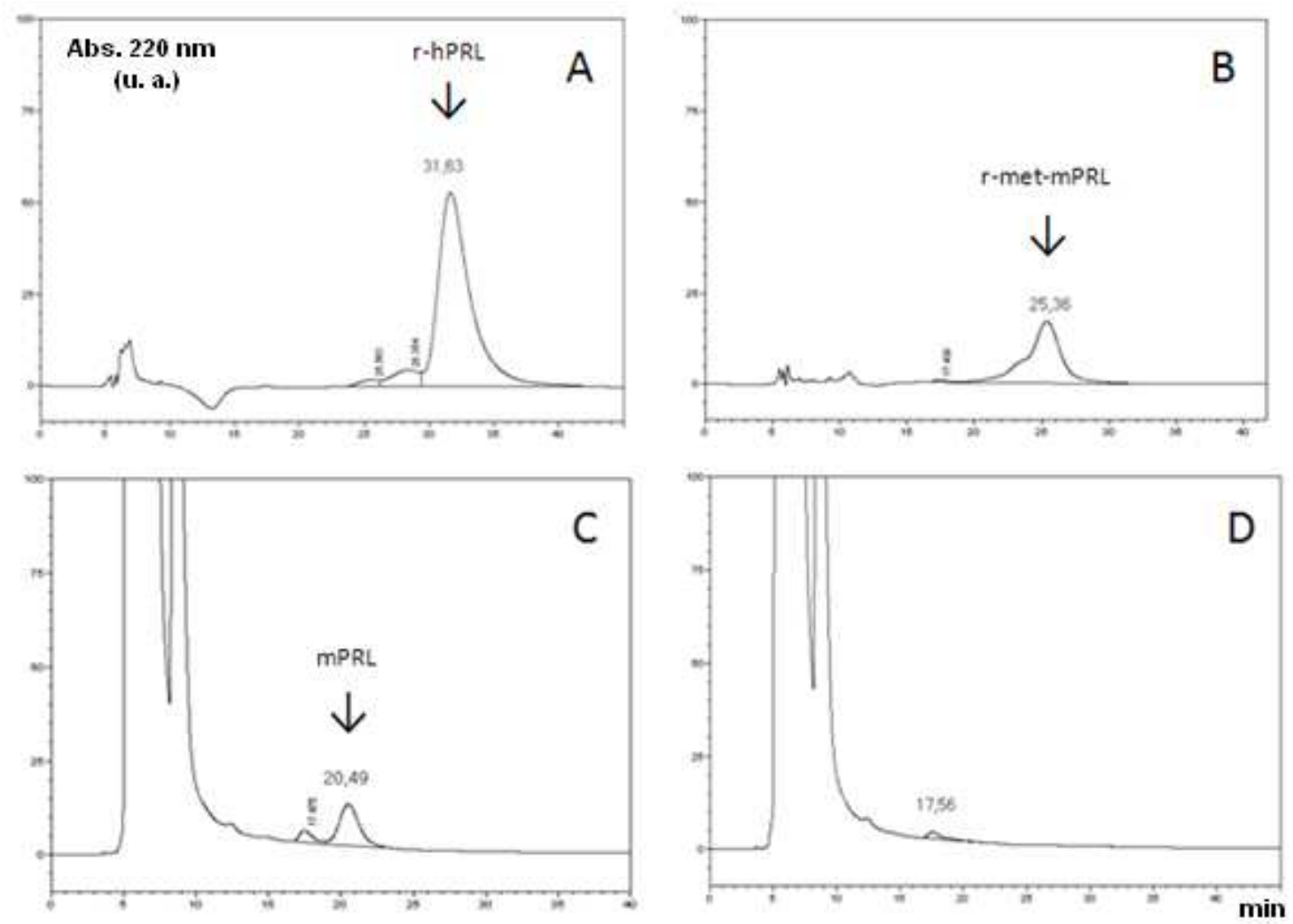

FIGURA 14. Exemplos de cromatogramas relativos às análises em RP-HPLC, utilizando como fase móvel Tris-HCl e n-propanol. (A) r-hPRL $(7 \mu \mathrm{g})$, (B) r-met-

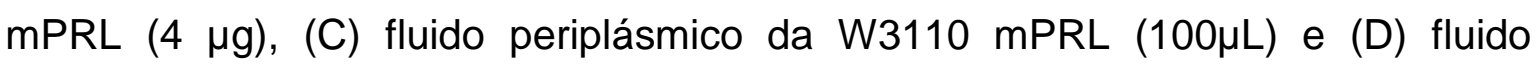

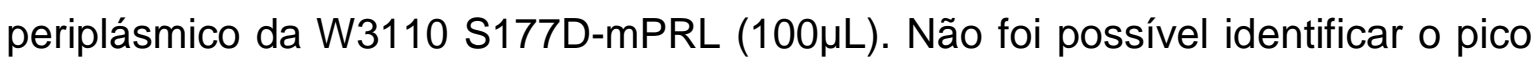
correspondente ao antagonista S177D-mPRL. 
Como já mencionado, um parâmetro importante como controle de identidade no caso do HPLC de fase reversa é o tempo de retenção relativo ( $\left.t_{R R}\right)$. Quando analisamos o fluido periplásmico dos clones produtores de mPRL por RPHPLC, obtivemos $t_{R R}$ inferiores ao da hPRL (TAB. 4 e FIG. 14). É importante observar que a $\mathrm{mPRL}$ obtida do fluido periplásmico, portanto, sem a metionina inicial, possui tempo de retenção menor do que a r-met-mPRL de referência. De fato, a presença da metionina inicial como, no caso do padrão $r$-mPRL, pode alterar a hidrofobicidade do hormônio, conforme relatado por Riggin e colaboradores (1987) em estudo realizado com hGH, onde o hGH com metionina apresentou um tempo de retenção maior em 5 minutos.

TABELA 4. Tempos de retenção absolutos $\left(t_{R}\right)$ e relativos ( $\left.t_{R R}\right)$ observados na análise em RP-HPLC dos hormônios r-hPRL (padrão interno P35), r-met-mPRL (NIH/NIDDK) e W3110 mPRL.

\begin{tabular}{ccc}
\hline Hormônio & $\begin{array}{c}\text { RP-HPLC } \\
\mathbf{t}_{\mathbf{R}}(\mathbf{m i n})\end{array}$ & $\begin{array}{c}\mathbf{t}_{\mathbf{R R}} \\
\text { (r-hPRL) }\end{array}$ \\
\hline r-hPRL & 31,63 & 1,0 \\
r-met-mPRL & 25,36 & 0,8 \\
W3110 $\mathbf{m P R L}$ & 20,49 & 0,6 \\
\hline
\end{tabular}


O fluido periplásmico também foi analisado por SDS-PAGE e WB. Observamos no SDS-PAGE que a banda correspondente ao padrão r-met-mPRL, está um pouco abaixo da posição da r-hPRL (FIG. 15), como já observado também na FIG. 8. É interessante também observar que a r-met-mPRL (198 aa) migra sensivelmente mais que a hPRL (199 aa), como já observado anteriormente.

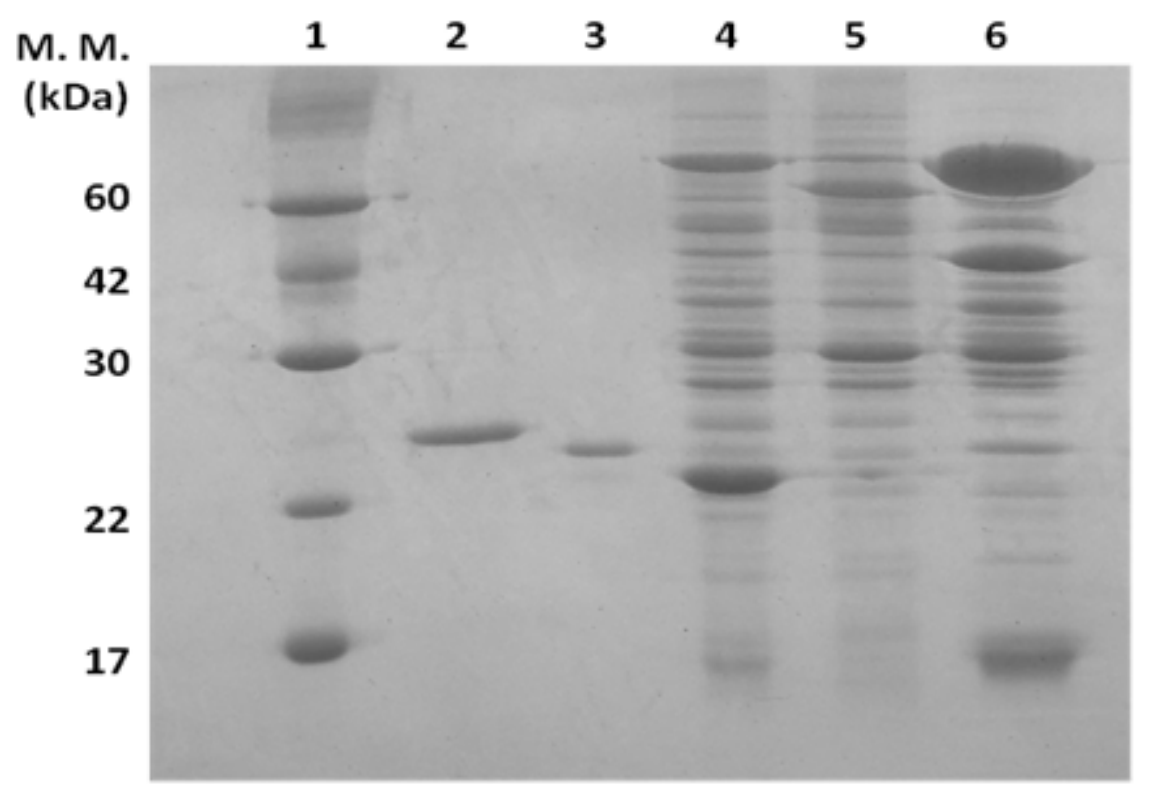

FIGURA 15. Análise em SDS-PAGE, em condições não redutoras, de fluidos periplásmicos obtidos de choque osmótico.

(1) Marcador de massa molecular;

(2) r-hPRL (P35), $560 \mathrm{ng}(199 \mathrm{aa}, 22898 \mathrm{Da})$;

(3) r-met-mPRL, $540 \mathrm{ng}(198 \mathrm{aa}, 22553 \mathrm{Da})$;

(4) Fluido periplásmico da cepa $\mathrm{W} 3110 \mathrm{hGH}, 15 \mu \mathrm{L}$;

(5) Fluido periplásmico da cepa RB791 mPRL, $15 \mu \mathrm{L}$;

(6) Fluido periplásmico da cepa W3110 mPRL, $15 \mu \mathrm{L}$. 
No WB da FIG. 16 observamos que as bandas correspondentes aos vários clones produtores de mPRL são bem intensas e por outro lado as bandas correspondentes ao antagonista mPRL-S177D são extremamente fracas, confirmando os baixos níveis de expressão do antagonista (FIG. 16). Ressaltamos como a troca de apenas um aminoácido pode alterar tão significativamente a expressão dessa proteína. Isto é provavelmente devido às alterações estruturais na proteína, também responsáveis pela esperada ação antagonista. Observamos ainda que a mPRL (197 aa, $22439 \mathrm{Da})$ e a S177DmPRL (197 aa, $22439 \mathrm{Da}$ ) apresentam bandas na mesma posição da r-met-mPRL (198 aa, $22553 \mathrm{Da}$ ). Isto significa que a diferença eletroforética entre a r-met$\mathrm{mPRL}$ e a $\mathrm{hPRL}$ é devida às diferenças na estrutura e conformação da molécula e não à diferença na massa molecular.

\section{$\begin{array}{llllllllll}1 & 2 & 3 & 4 & 5 & 6 & 7 & 8 & 9 & 10\end{array}$}

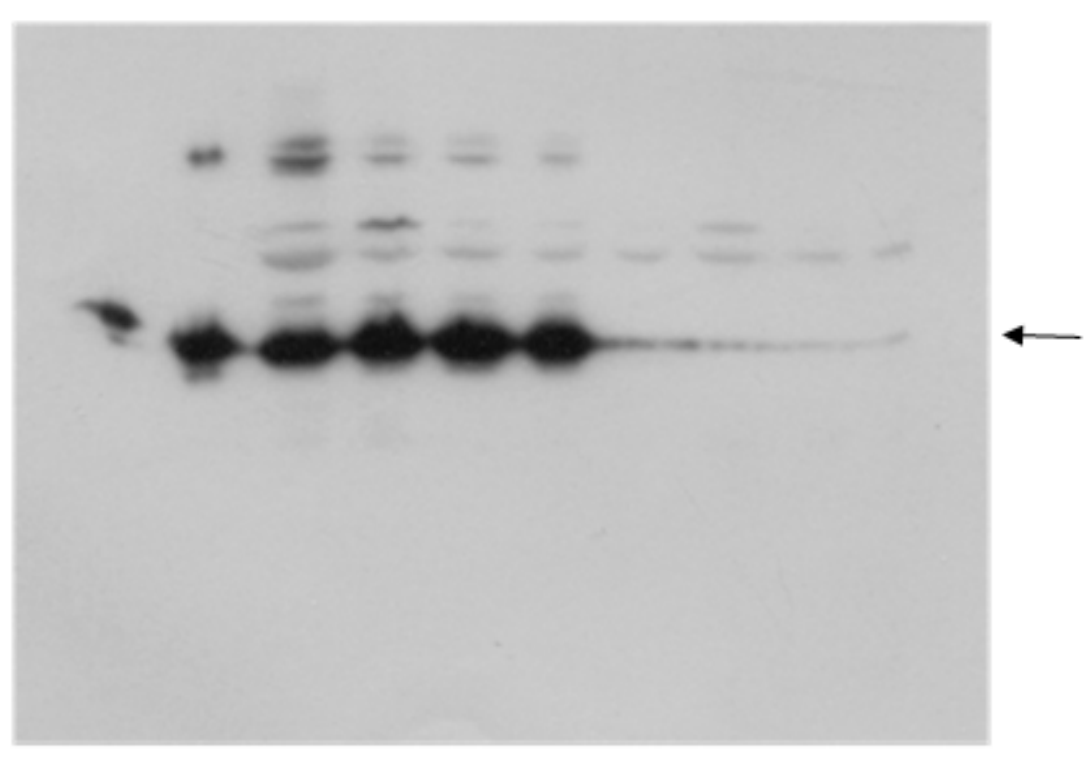

FIGURA 16. Análise em WB de amostras contendo mPRL e S177D-mPRL obtidas de choque osmótico da cepa W3110 de E. coli. (1) r-hPRL (200 ng) (199 aa, $22898 \mathrm{Da}$ ), (2) r-met-mPRL (54 ng) (198 aa, $22553 \mathrm{Da}$ ), (3) a (6) fluido periplásmico de clones expressando mPRL (197 aa, $22433 \mathrm{Da}) 15 \mu \mathrm{L}$, (7) a (10) fluido periplásmico de clones expressando S177D-mPRL (197 aa, $22439 \mathrm{Da}) 15$ $\mu \mathrm{L}$. Foi utilizado soro anti-mPRL. 


\subsubsection{Caracterização da mPRL após purificação parcial}

Para melhor caracterização da $\mathrm{mPRL}$ produzida no espaço periplásmico, realizamos uma semi-purificação rápida de uma única etapa, utilizando a RPHPLC. Aplicamos $500 \mu \mathrm{L}$ de fluido periplásmico e o pico correspondente à mPRL (FIG. 17A) foi coletado e analisado na HPSEC (FIG. 17B) e por WB (FIG. 17C). Observamos que a mPRL, analisado por HPSEC, apresentou o mesmo $T_{r}$ da $r$ met-mPRL (FIG. 17B) e a banda da mPRL foi revelada na mesma posição do padrão (FIG. 17C).
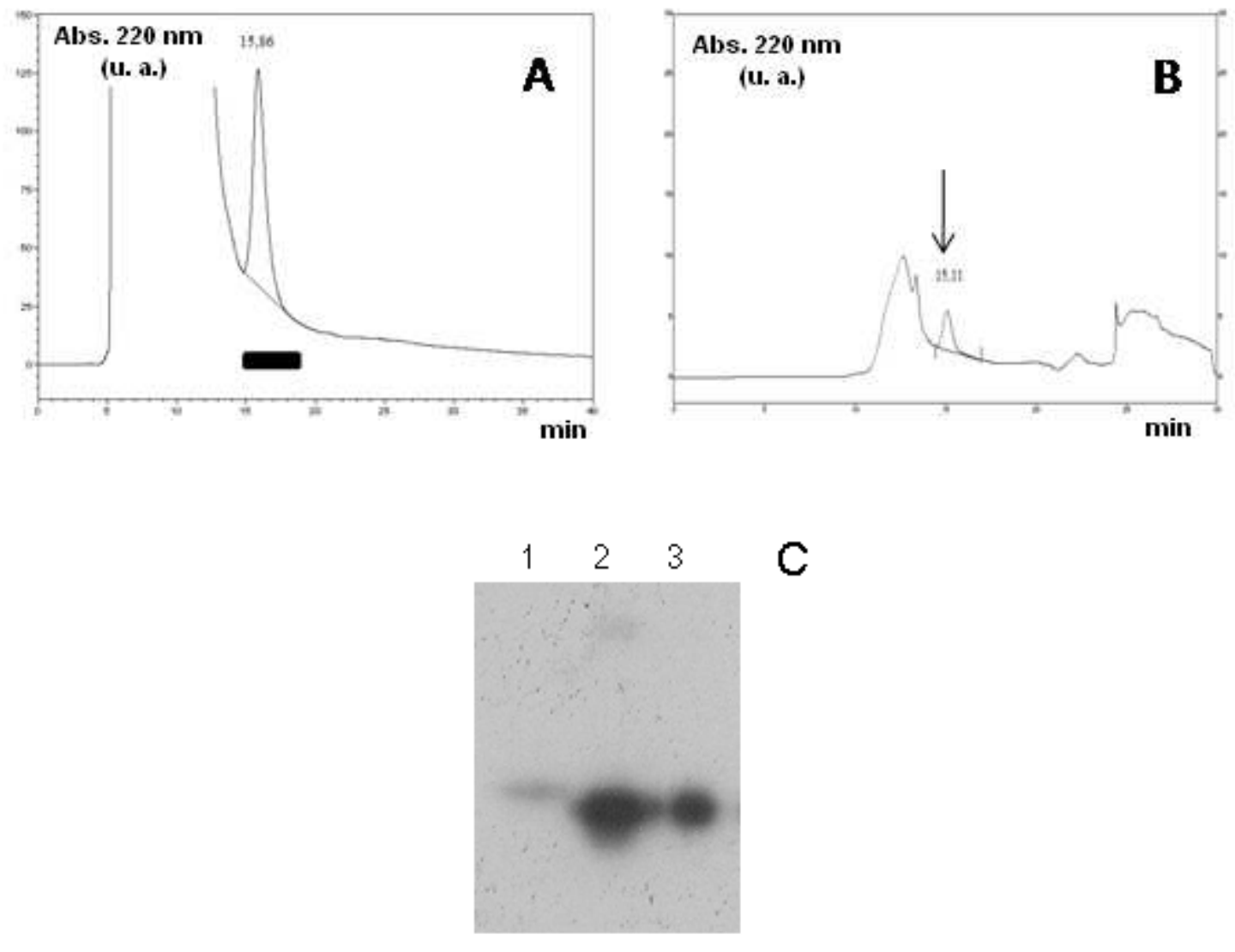

FIGURA 17. Análise da mPRL obtida de $500 \mu \mathrm{L}$ de choque osmótico da cepa W3110 de E. coli. (A) Análise em RP-HPLC, utilizando Tris-HCl e n-propanol. A barra indica as frações coletadas do pico correspondente à mPRL. (B) Análise em HPSEC do pico coletado da RP-HPLC, utilizando bicarbonato de amônio $0,025 \mathrm{M}$, $\mathrm{pH} 7,0$. A seta indica a posição do pico do padrão r-met-mPRL. (C) Análise em WB: (1) r-hPRL (110 ng), (2) r-met-mPRL (54 ng), (3) pico da suposta mPRL coletado da RP-HPLC. Foi utilizado soro anti-mPRL. 


\subsection{Estudos alternativos com objetivo de incrementar a expressão bacteriana}

Em busca de alternativas para aumentar os níveis de expressão bacteriana e também para compreender melhor o porquê da expressão tão baixa do antagonista realizamos alguns estudos que serão detalhados a seguir.

\subsubsection{Influência da temperatura de cultivo sobre a expressão da mPRL}

Estudos anteriores realizados pelo nosso grupo mostraram que a expressão da hPRL em bactérias sofre forte influência da temperatura de cultivo (Soares e col., 2008). Avaliamos esse efeito na expressão da mPRL. Após crescimento à $30^{\circ} \mathrm{C}$, até $\mathrm{DO}$ de 1,5 , comparamos a expressão após ativação, em diferentes temperaturas: $25,30,32,35,37$ e $42^{\circ}$ C. Os dados de expressão após análise do fluido periplásmico por RP-HPLC são apresentados na TAB. 5.

TABELA 5. Expressão de mPRL (E. coli cepa W3110) em frascos (100 mL meio LB com 0,1 mg/mL ampicilina) após choque osmótico e quantificação em RPHPLC (volume aplicado $100 \mu \mathrm{L})(\mathrm{n}=3)$.

\begin{tabular}{cc}
\hline Temperatura $\left({ }^{\circ} \mathrm{C}\right)$ & $\begin{array}{c}\mathrm{mPRL}\left(\boldsymbol{\mu g} / \mathrm{mL} / \mathbf{A}_{600}\right) \\
\text { médias } \pm \mathbf{d p}\end{array}$ \\
\hline 25 & $0,025 \pm 0,012$ \\
30 & $0,130 \pm 0,041$ \\
32 & $0,100 \pm 0,011$ \\
35 & $0,097 \pm 0,065$ \\
37 & $0,101 \pm 0,030$ \\
42 & $0,024 \pm 0,002$ \\
\hline
\end{tabular}

Os resultados mostram que a expressão de $\mathrm{mPRL}$ não teve aumento significativo entre as temperaturas de $30^{\circ} \mathrm{C}$ e $37^{\circ} \mathrm{C}$, embora a ativação a $30^{\circ} \mathrm{C}$ tenha apresentado um pequeno incremento ( $p>0,05$, teste $t$ de Student). Temperaturas abaixo de $25^{\circ} \mathrm{C}$ e acima de $42^{\circ} \mathrm{C}$, no entanto já apresentam sensível queda na expressão. 


\subsubsection{Análise do lisado bacteriano}

Como descrito em Soares e colaboradores (2008), a análise do lisado bacteriano forneceu fortes indicativos da instabilidade da $\mathrm{hPRL}$ quando presente no citoplasma bacteriano, instabilidade essa fortemente influenciada pela temperatura de cultivo. Com base nessas informações, realizamos estudos similares com as cepas produtoras de mPRL e seu antagonista (FIG. 18).

Nossos resultados mostram que principalmente o antagonista S177DMPRL é extremamente instável no ambiente citoplasmático. A análise por WB do lisado bacteriano $\left(37^{\circ} \mathrm{C}\right)$ da cepa responsável pela síntese do antagonista apresenta bandas bem mais intensas em posições não correspondentes a mPRL, do que aquelas encontradas tanto no lisado da mesma cepa cultivada a $30^{\circ} \mathrm{C}$ ou da cepa responsável pela síntese da mPRL. A análise do fluido periplásmico bacteriano confirma que o antagonista (FIG. 18, corridas 9 e 10) está muito menos presente no periplasma em comparação com a mPRL (FIG. 18, corrida 5).

Os resultados indicam que provavelmente as enzimas proteolíticas presentes no citoplasma bacteriano da nossa cepa agiram sobre o antagonista S177D-mPRL ou sobre seu precursor, tornando inviável a expressão dessa proteína no nosso modelo. Uma alternativa para minimizar esse problema é utilizar um hospedeiro que contenha menos proteases. 


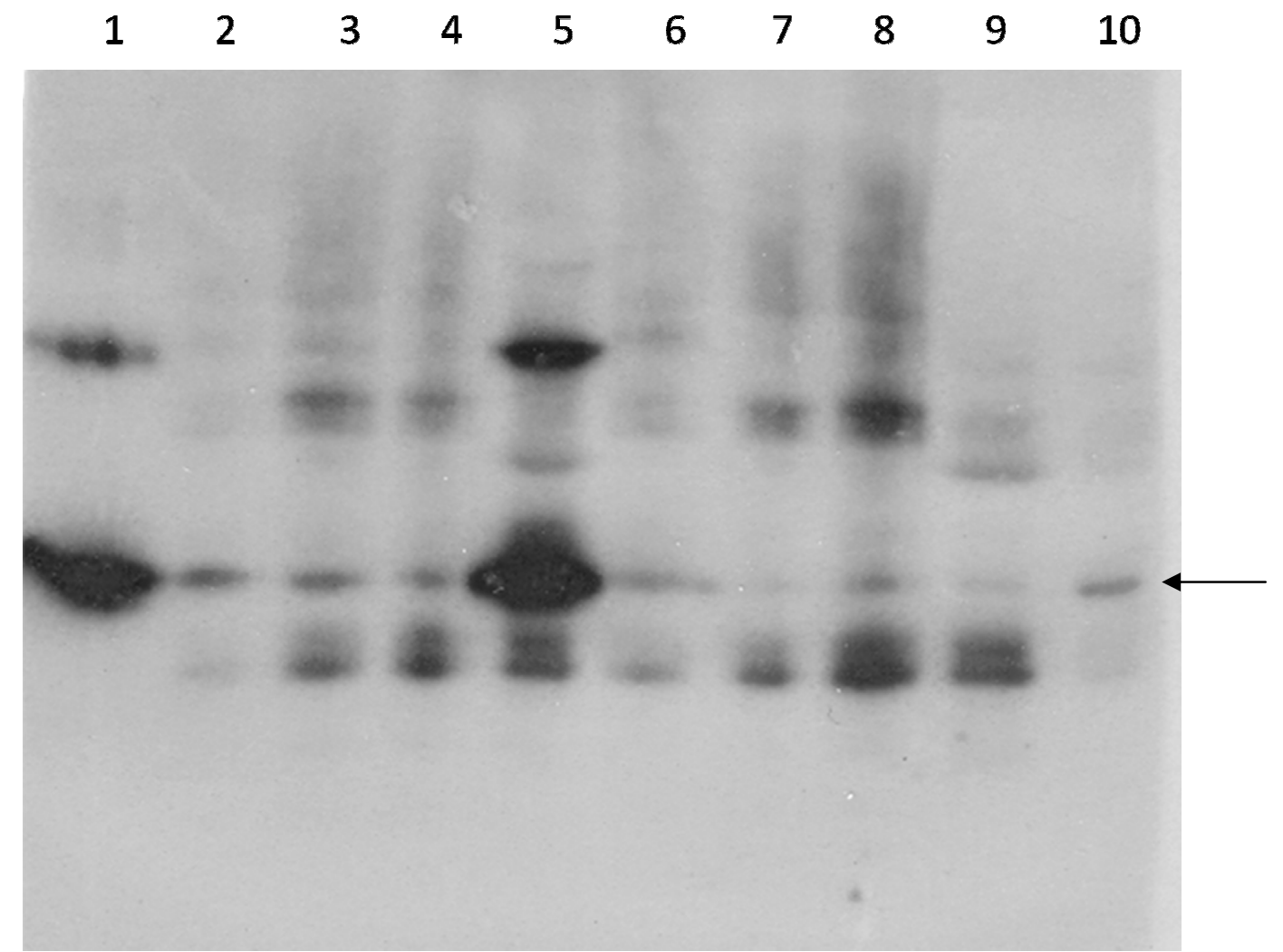

FIGURA 18. Análise em WB de amostras contendo mPRL e S177D-mPRL obtidas de E. coli cepa W3110. O lisado bacteriano aplicado corresponde a 0,02 DO $\left(A_{600}\right)$. Foram analisados $20 \mu \mathrm{L}$ de fluido periplásmico, equivalentes a $2 \mathrm{DO}$ $\left(A_{600}\right)$. Foi utilizado soro anti-mPRL. A seta indica a posição da r-met-mPRL (22553 Da).

(1) r-met-mPRL (50 ng);

(2) Lisado de bactérias W3110-mPRL antes da ativação;

(3) Lisado de bactérias W3110-mPRL após $6 \mathrm{~h}$ a $30^{\circ} \mathrm{C}$;

(4) Lisado de bactérias W3110-mPRL após $6 \mathrm{~h}$ a $37^{\circ} \mathrm{C}$;

(5) Fluido periplásmico da W3110-mPRL após $6 \mathrm{~h}$ a $30^{\circ} \mathrm{C}, 2 \mathrm{DO}$;

(6) Lisado de bactérias W3110-S177D-mPRL antes da ativação;

(7) Lisado de bactérias W3110-S177D-mPRL após $6 \mathrm{~h}$ a $30^{\circ} \mathrm{C}$;

(8) Lisado de bactérias W3110-S177D-mPRL após $6 \mathrm{~h}$ a 37우 $\mathrm{C}$;

(9) Fluido periplásmico da W3110-S177D-mPRL após $6 \mathrm{~h}$ a 30 $\mathrm{C}, 2 \mathrm{DO}$;

(10) Fluido periplásmico da W3110-S177D-mPRL após 6 h a 37º C, 2 DO. 


\subsubsection{Estudos com a cepa Rosetta-gami B}

Com o objetivo de aumentar os níveis de expressão da $\mathrm{mPRL}$ e do antagonista S177D-mPRL realizamos também estudos com outra cepa de $E$. coli: a Rosetta-gami ${ }^{T M}$ B. Essa cepa é derivada da cepa OrigamiTM (K-12), BL21 e Rosetta $^{\mathrm{TM}}$ e foi concebida para aumentar a expressão de proteínas de eucariotos e a formação de pontes dissulfeto no citoplasma bacteriano. Apresenta plasmídeos contendo seis tRNAs raros, facilitando a expressão de genes de códons raros da $E$. coli, possui mutação no gene trxB/gor, que facilita a formação de pontes dissulfeto no citoplasma e deleção no gene BL21 lacZY. Esta cepa é compatível com vetores construídos com os promotores TAC, trc, T5 e $\lambda$ que possuem origem de replicação ColE-1 (como pBR e pUC) e que apresentem sequência para resistência à ampicilina.

No entanto, os resultados obtidos não foram satisfatórios. A banda correspondente à proteína de interesse apresentou fraca intensidade e as principais bandas observadas apareceram em posições diferentes da esperada, mesmo aplicando volume de choque quatro vezes superiores que a cepa W3110 mPRL (FIG. 19). 


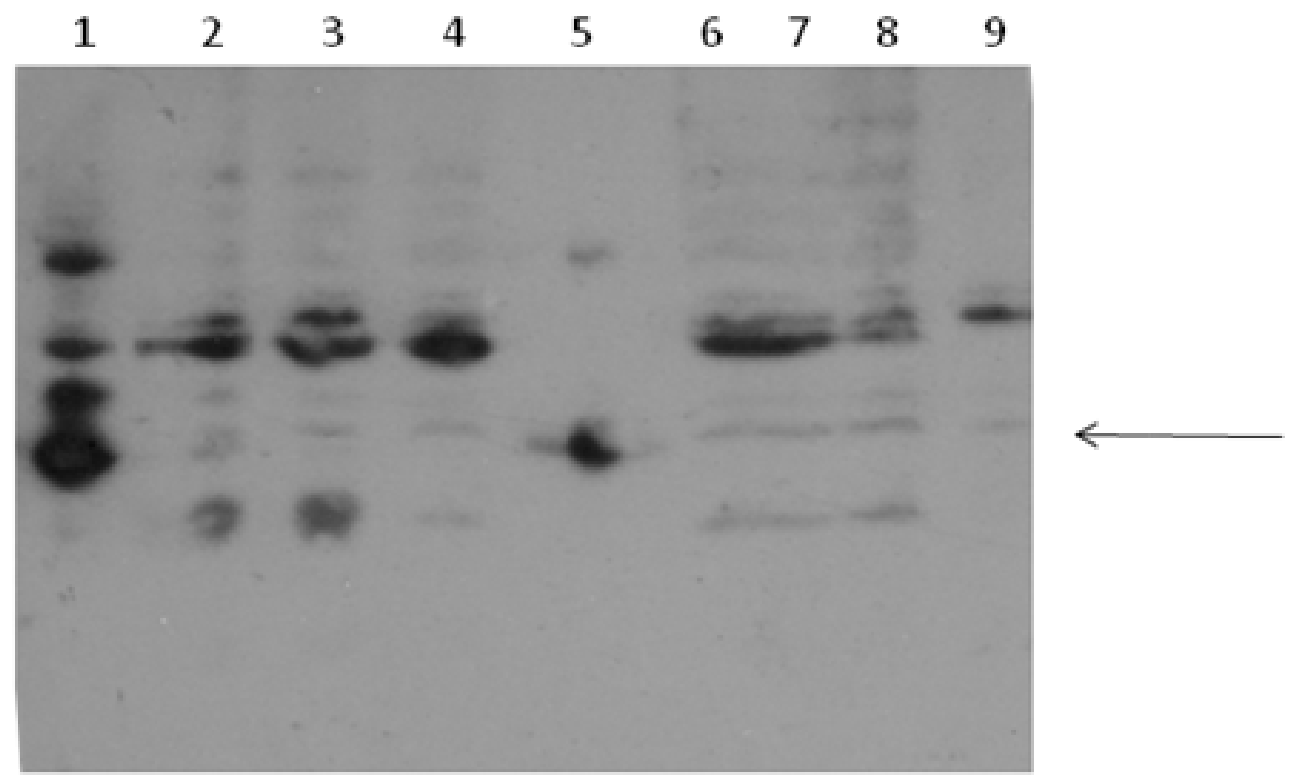

FIGURA 19. Análise em WB de amostras de fluido periplásmico obtidas de choque osmótico de E. coli. A seta indica a posição da r-met-mPRL (22553 Da).

(1) MPRL cepa W3110 clone 3;

(2) S177D-mPRL Rosetta-gami TM B clone 1;

(3) S177D-mPRL Rosetta-gami ${ }^{\mathrm{TM}} \mathrm{B}$ clone 2;

(4) S177D-mPRL Rosetta-gami TM B clone 3;

(5) r-met-mPRL (54 ng);

(6) MPRL Rosetta-gami ${ }^{\mathrm{TM}}$ B clone 1;

(7) MPRL Rosetta-gami ${ }^{\mathrm{TM}} \mathrm{B}$ clone 2;

(8) mPRL Rosetta-gami ${ }^{\mathrm{TM}} \mathrm{B}$ clone 3;

(9) mPRL Rosetta-gami ${ }^{\mathrm{TM}} \mathrm{B}$ clone 4.

Optamos por prosseguir com a fermentação, purificação e caracterização da MPRL produzida pela E. coli cepa W3110 e começamos a estudar outra estratégia para a obtenção do análogo/antagonista S177D-mPRL, desta vez utilizando células de mamífero $(\mathrm{CHO})$ como realizado com o antagonista humano S179D-hPRL (Soares e col., 2006). 


\subsection{Análise da expressão da mPRL no periplasma de $E$. coli em biorreator}

Seguimos os estudos com a cepa produtora de MPRL focalizando sua produção em biorreator. A fermentação em biorreator foi realizada com a cepa mPRL-W3110 (clone 3), seguindo o protocolo já estabelecido em nosso laboratório para a hPRL (Soares e col., 2008). Após a ativação foram coletadas amostras a cada hora (T0 a T6) (FIG. 20). A análise do fluido periplásmico mediante RP-HPLC utilizando o padrão de $\mathrm{mPRL}$ mostrou que a expressão no tempo T6, final da fermentação, foi de 0,081 $\mu \mathrm{g} \mathrm{mPRL} / \mathrm{mL} / \mathrm{A}_{600}$. A análise das amostras T4 e T5 apresentaram valores de 0,078 e 0,096 $\mu \mathrm{g} \mathrm{mPRL} / \mathrm{mL} / \mathrm{A}_{600}$, respectivamente (FIG. 20). Como controle utilizamos cultivo paralelo em frasco com $100 \mathrm{~mL}$ de meio LB derivado do inóculo que apresentou 0,120 $\mu \mathrm{g}$ $\mathrm{mPRL} / \mathrm{mL} / \mathrm{A}_{600}$. Observamos que com $5 \mathrm{~h}$ de ativação houve maior produção de mPRL, conforme avaliação por RP-HPLC, indicando que o processo de fermentação pode ser encerrado após 5 h de ativação.

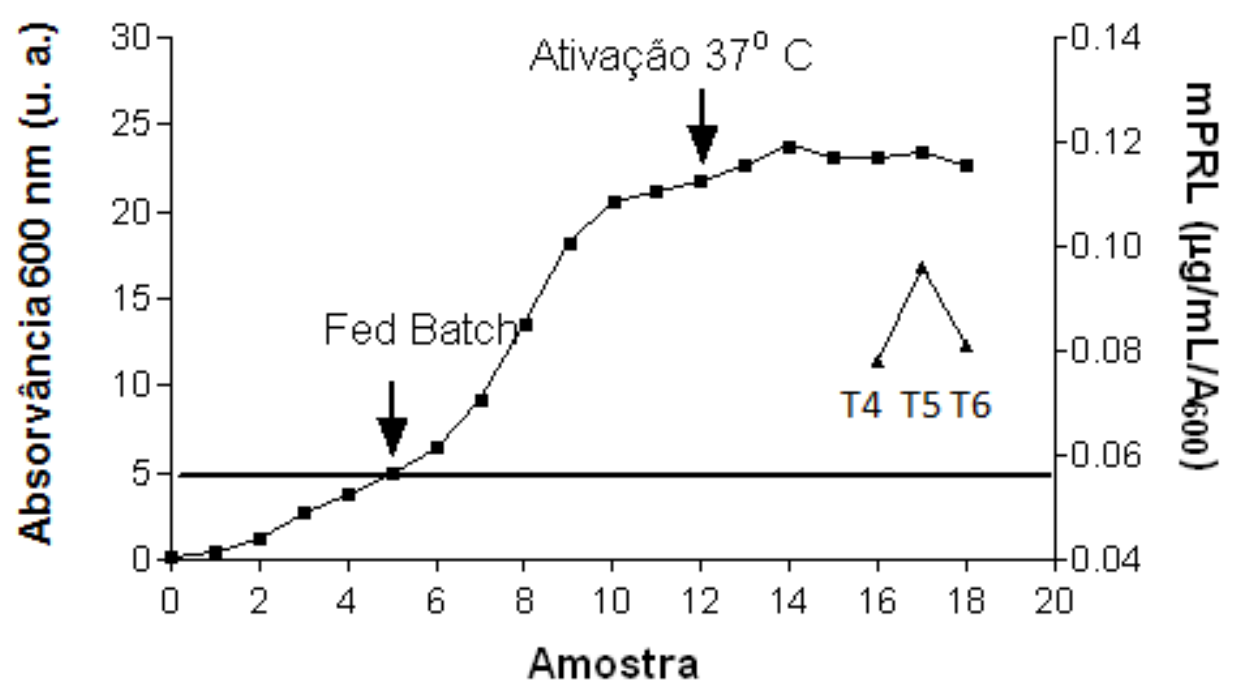

FIGURA 20. Fermentação da cepa W3110 mPRL clone 3 em biorreator no volume de $5 \mathrm{~L}$, fase de crescimento a $30^{\circ} \mathrm{C}$. O Fed Batch foi iniciado com $\mathrm{A}_{600}=5$ unidades e ativação por elevação da temperatura para $37^{\circ} \mathrm{C}$ quando foi atingido 0 platô de crescimento (-m-). Observamos que 5 h após ativação (T5) houve uma maior produção de mPRL, avaliada por RP-HPLC (- $\mathbf{\Delta}-)$. 
Comparando-se com os valores de expressão obtidos nas fermentações em frascos com a cepa W3110 produtora de $h P R L$ do laboratório $(0,80 \pm 0,16 \mu \mathrm{g}$ $\left.\mathrm{hPRL} / \mathrm{mL} / \mathrm{A}_{600}, \mathrm{n}=3\right)$, verificamos que a produção obtida de $\mathrm{mPRL}(0,08 \mu \mathrm{g}$ $\left.\mathrm{mPRL} / \mathrm{mL} / \mathrm{A}_{600}\right)$, é 10 vezes inferior. Essa relativa baixa expressão dificulta acentuadamente os rendimentos de purificação e conseqüentemente de produção.

\subsection{Purificação da mPRL produzida no biorreator}

Para a purificação da $\mathrm{mPRL}$, que apresentou provavelmente uma fração de massa muito baixa no fluido periplásmico de E. coli obtido de biorreator (FIG. 20), optamos por desenvolver um processo baseado na ótima eficiência de separação do HPLC de fase reversa.

Esse novo processo de purificação pode ser dividido em 3 etapas: concentração e purificação do produto obtido do choque osmótico em Phenyl Sepharose CL-4B; purificação por RP-HPLC; troca de tampão (diálise) e purificação por HPSEC. Descreveremos a seguir cada uma dessas etapas de forma mais detalhada.

\subsubsection{Concentração e primeira purificação da mPRL presente no fluido periplásmico}

Essa etapa foi realizada utilizando uma coluna com resina Phenyl Sepharose CL-4B. Essa resina de separação hidrofóbica apresenta as vantagens de concentrar a proteína de interesse, realizar uma purificação parcial da $\mathrm{MPRL} e$ não exige prévio tratamento da amostra como por exemplo diálise ou ajuste de $\mathrm{pH}$. Exigiu somente a adição de acetato de amônio até uma osmolaridade inicial de 0,4 M. Um exemplo do perfil cromatográfico dessa etapa é apresentado na FIG. 21A. 

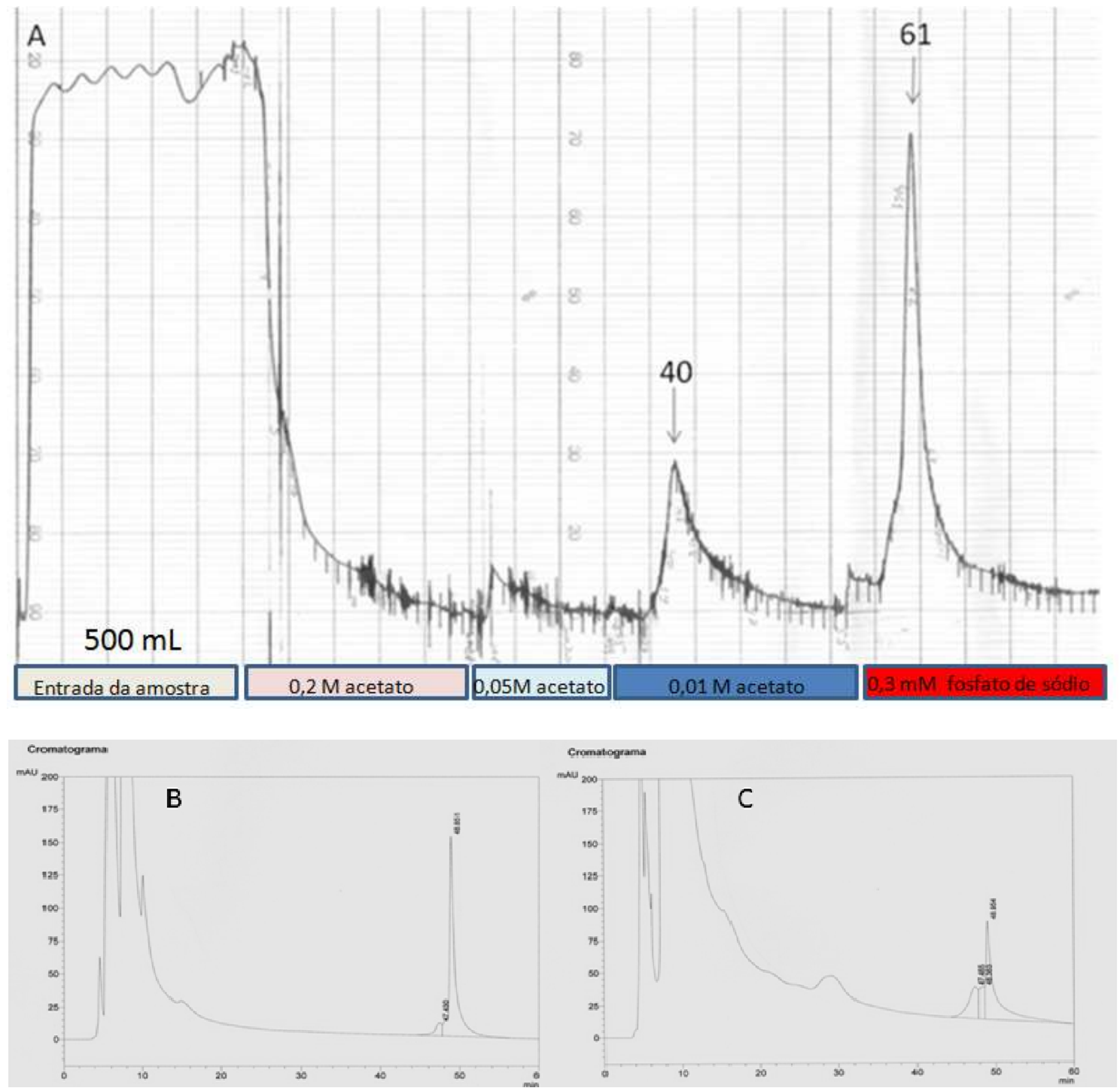

FIGURA 21. Cromatograma da purificação em Phenyl Sepharose CL-4B (A) do fluido resultante do choque $\mathrm{mL}$ osmótico (amostra de $500 \mathrm{~mL}$ ) eluído em acetato de amônio 0,2 M; 0,05 M e 0,01 M e tampão fosfato de sódio 0,3 mM. As frações coletadas \#40 (B) e \#61 (C) foram analisadas em RP-HPLC (volume aplicado 100 $\mu \mathrm{L})$. A fase móvel consistiu de fosfato de sódio 0,05 $\mathrm{M}$ e acetonitrila $43 \%$ (0 - 30 $\min )$ e $50 \%$ (31 - $60 \mathrm{~min}), \mathrm{pH} 7,0$.

As análises por RP-HPLC de algumas frações obtidas mostraram que o principal pico de eluição da mPRL corresponde às frações \#39 a \#46 (lavagem com acetato de amônia 0,01 M). É interessante destacar que a lavagem com o tampão fosfato de sódio 0,3 $\mathrm{mM}$, responsável pelo pico entre as frações \#59 a \#66, também apresentou $\mathrm{mPRL}$, porém em quantidade aproximadamente dez vezes menor, sendo que grande parte da $\mathrm{MPRL}$ parece apresentar formas 
alteradas, supostamente devido a sulfóxidos, desamidados ou formas clivadas (FIG. 21B e C). Essa etapa, apesar das vantagens mencionadas, apresentou uma recuperação relativamente baixa ( 20\%), considerando somente o pico principal (\#39 a \#46) no qual foi determinada a presença de $463 \mu \mathrm{g}$ de mPRL. 


\subsubsection{Purificação por RP-HPLC}

Nos estudos iniciais utilizando a RP-HPLC como coluna preparativa observamos que o tampão com aproximadamente $28 \%$ de n-propanol, correspondente à fase móvel, provocava a agregação e precipitação de parte da mPRL purificada. Para contornar esse problema desenvolvemos uma nova metodologia substituindo o n-propanol por acetonitrila.

Com o objetivo de melhor purificar a $\mathrm{MPRL}$ derivada da Phenyl Sepharose CL-4B, a cromatografia foi realizada em duas fases: uma com duração de 30 minutos com fase móvel composta por $43 \%$ e outra com $50 \%$ de acetonitrila, até a eluição da mPRL. Um exemplo de cromatograma é apresentado na FIG. 22, onde podemos observar um pico bem definido para a mPRL. A análise por HPSEC do material coletado mostrou que o uso dessa coluna com função preparativa apresentou uma alta recuperação ( 100\%), obtendo-se mPRL praticamente pura, na sua maior parte na forma monomérica, porém em solução com $50 \%$ de acetonitrila.

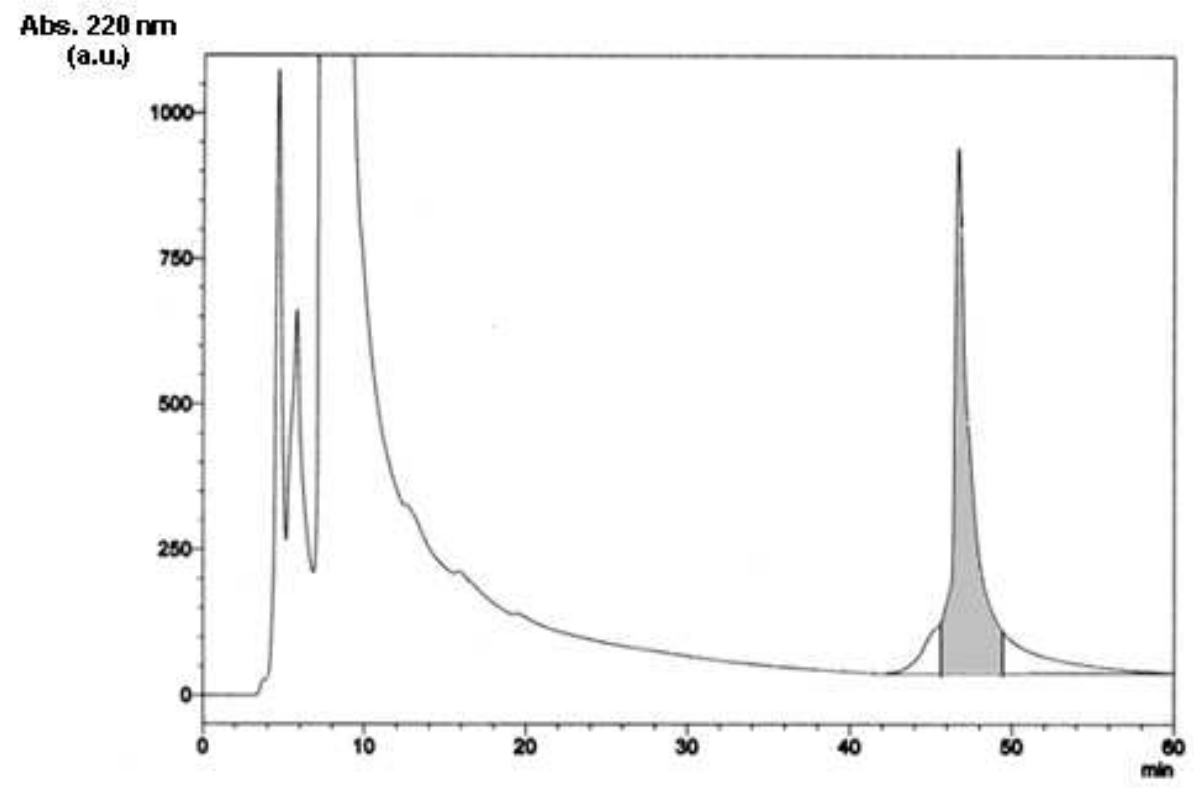

FIGURA 22. Cromatograma obtido por RP-HPLC, do material derivado do pool composto pelos tubos 39 a 46 coletados da coluna de Phenyl Sepharose CL-4B (pico principal) e concentrado em coluna Amicon Ultra (20 vezes). A parte hachurada representa a fração coletada de $\mathrm{mPRL}$ e aplicada na HPSEC. Foram aplicados $500 \mu \mathrm{L}$ de amostra e como fase móvel utilizou-se fosfato de sódio 0,05 $\mathrm{M}, \mathrm{pH} 7,0$ com acetronitrila $43 \%$ (0 - $30 \mathrm{~min})$ e $50 \%$ (31 - $60 \mathrm{~min})$. 


\subsubsection{Purificação por HPSEC}

Realizamos uma cromatografia por HPSEC aplicando $500 \mu \mathrm{L}$ do produto obtido da RP-HPLC (FIG. 23). Além da avaliação analítica em SDS-PAGE (FIG. 24A) e HPSEC (FIG. 24B) mostrando o alto grau de pureza da mPRL coletada da RP-HPLC essa cromatografia por HPSEC serviu como coluna preparativa, refinando ainda mais a purificação, com a coleta somente do pico principal e funcionou também como sistema de diálise pois realizou a troca de tampão da amostra, substituindo a acetonitrila por fosfato de sódio $0,05 \mathrm{M} \mathrm{pH} \mathrm{7,0.} \mathrm{O} \mathrm{t}_{\mathrm{R}}$ da rmet-mPRL quando utilizado fosfato de sódio (utilizado na purificação) é superior ao do bicarbonato de amônio (utilizado na caracterização). Após esta última coluna foram obtidos $408 \mu \mathrm{g}$ de $\mathrm{mPRL}$.

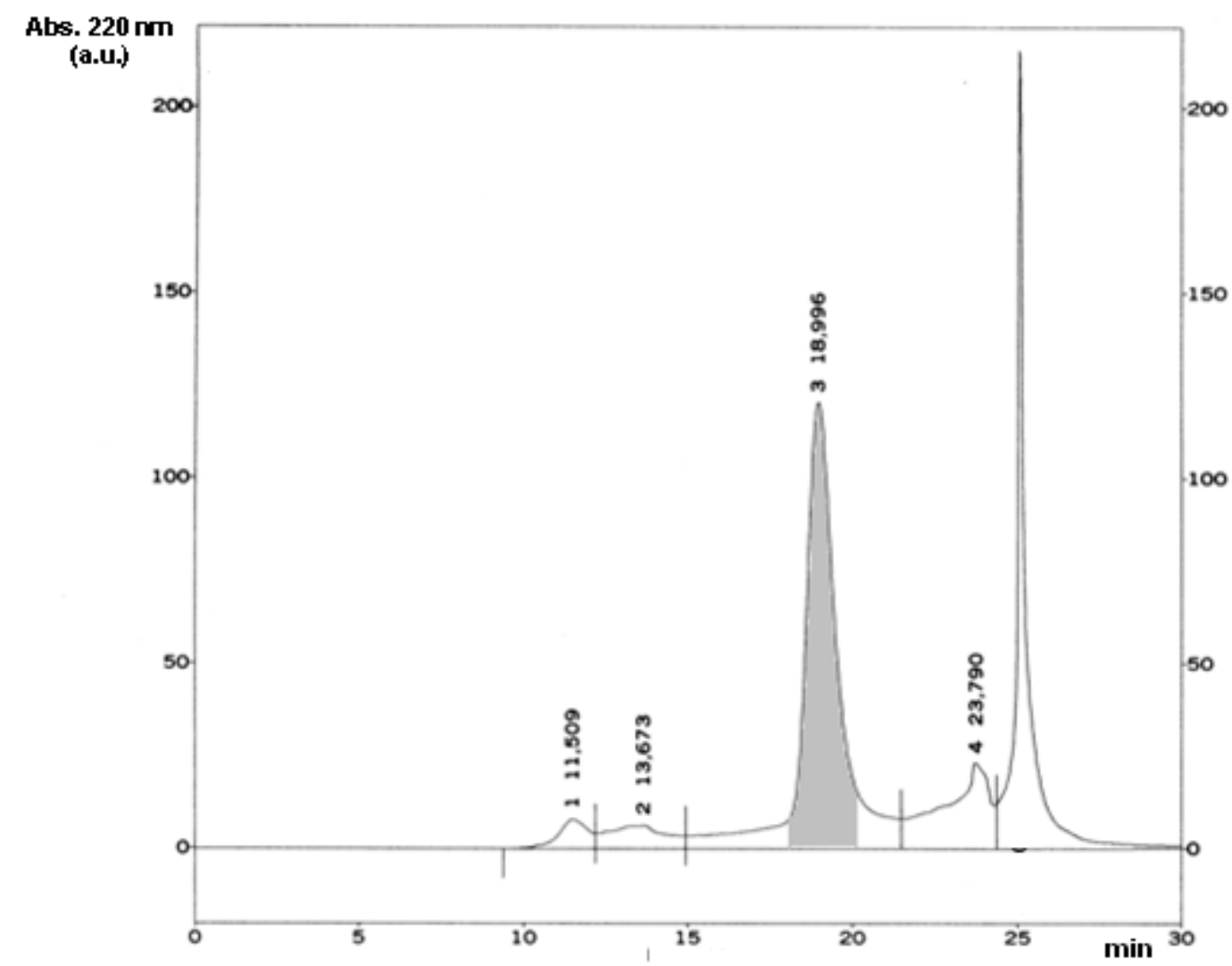

FIGURA 23. Análise cromatográfica por HPSEC do "pool" coletado da RP-HPLC. A parte hachurada representa a fração de $\mathrm{MPRL}$ coletado. Foi utilizado fosfato de sódio 0,05 M, pH 7,0. 
$\mathrm{Na}$ FIG. 24A mostramos as várias etapas da purificação em SDS-PAGE corado com nitrato de prata e observamos que já na coleta após RP-HPLC a mPRL se apresentou bastante pura (FIG. 24A, corrida 5), tendo sido eliminadas praticamente todas as moléculas de maior e menor massa molecular quando comparadas às corridas 2 e 3 (fluido periplásmico e coleta da Phenyl Sepharose CL-4B). Já na FIG. 24B, pode se observar que a mPRL (197 aa) eluiu com $t_{R} 19,8$ min, à direita da r-met-mPRL (198 aa) com $t_{R}$ 18,6 min. O pico principal representa $95 \%$ da área, portanto, concluímos que o produto final está $95 \%$ puro.
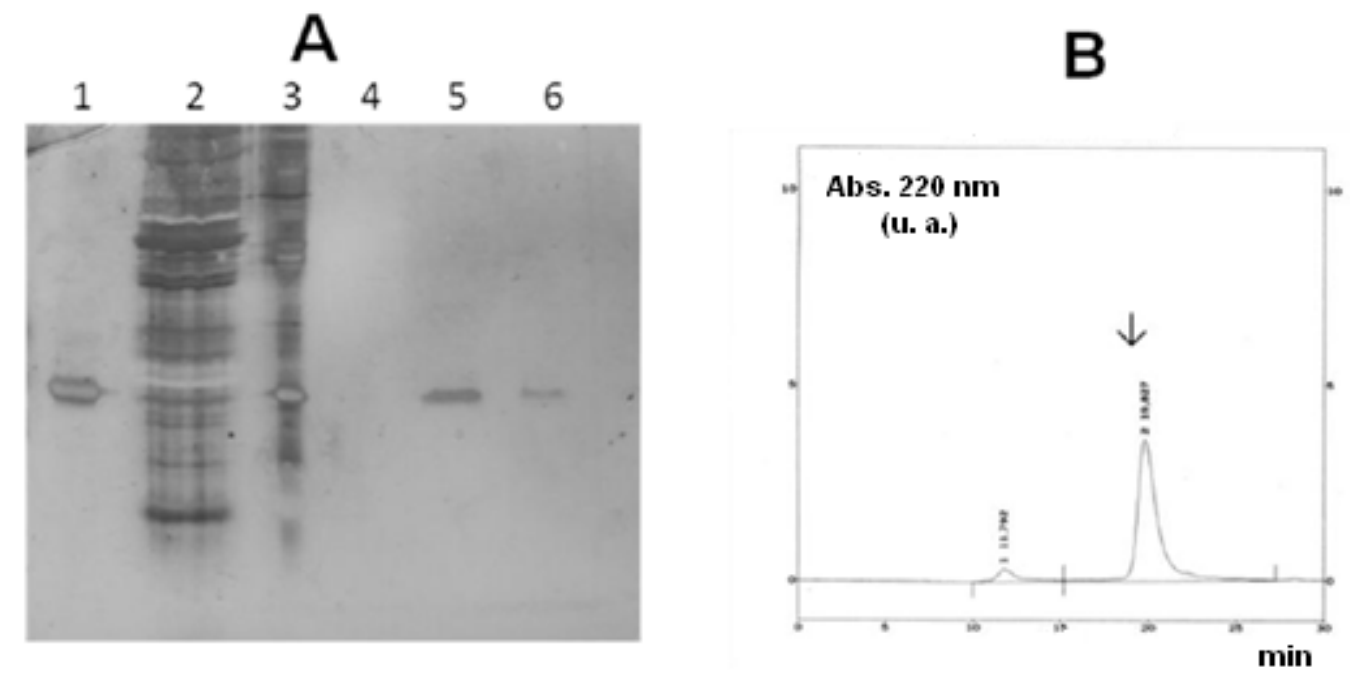

Figura 24. (A) SDS-PAGE revelado por nitrato de prata das amostras de mPRL durante as várias etapas de purificação. (1) r-met-mPRL (200 ng); (2) fluido periplásmico da W3110 mPRL clone 3; (3) pool principal da Phenyl Sepharose CL-4B, (4) sem amostra, (5) coleta da RP-HPLC; (6) coleta da HPSEC. (B) Cromatograma obtido por HPSEC, analisando $100 \mu \mathrm{L}$ da $\mathrm{mPRL}$ purificada. A seta indica $\circ t_{R}$ do padrão r-met-mPRL (18,6 min) menor que $\circ t_{R}$ da $\mathrm{mPRL}$ purificada (19,8 min). Foi utilizado tampão fosfato de sódio 0,05 M, pH 7,0.

Esse estudo mostrou que essa técnica de purificação pode ser bastante útil, principalmente no caso de amostras com pureza ou fração de massa extremamente baixa. 


\subsection{Ensaios biológicos com a MPRL purificada}

A bioatividade da $\mathrm{MPRL}$ purificada foi determinada usando o bioensaio clássico de proliferação com células Nb2 (Soares e col., 2008). Foi utilizado como padrão de referência o padrão de hPRL recombinante 97/714, da WHO (Organização Mundial de Saúde), com uma atividade específica de 57,2 \pm 11,4 IU/mg (Rafferty e col., 2001). Na comparação entre as duas curvas de proliferação, (amostra versus padrão), a potência biológica para a mPRL recombinante produzida no IPEN foi de 33,9 $\pm 1,4 \mathrm{UI} / \mathrm{mg}$ (Figura 25). A potência da r-met-mPRL, que já tinha sido determinada em 20,4 $\pm 2,1 \mathrm{UI} / \mathrm{mg}(\mathrm{n}=4)$, desta vez foi de $22,1 \pm 1,3 \mathrm{UI} / \mathrm{mg}$.

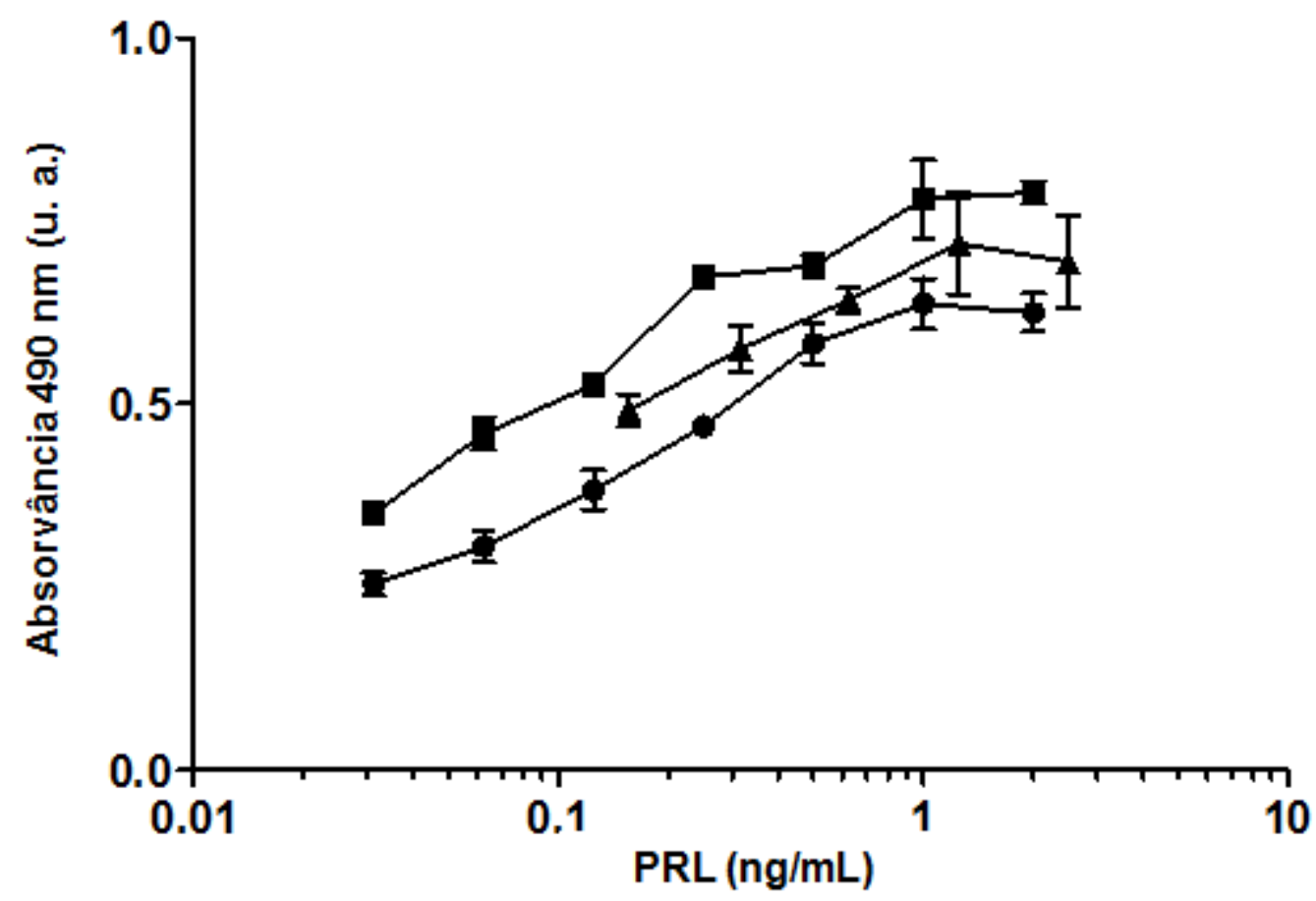

Figura 25. Curva dose-resposta com células Nb2. A potência da amostra de mPRL purificada (- $\boldsymbol{\Delta}$-) foi calculada em 33,9 \pm 1,4 Ul/mg, sendo $\mathrm{r}$-hPRL(-m-) com potência declarada de $57,2 \pm 11,4 \mathrm{IU} / \mathrm{mg}$ e a r-met-mPRL $(-\bullet-)$ com potência calculada em 22,1 $\pm 1,3 \mathrm{Ul} / \mathrm{mg}$. Cada ponto da curva foi obtido com amostras em triplicatas. 


\subsection{Construção dos vetores para células de mamífero}

Foram construídos com sucesso os vetores p658-S179D-hPRL e pEDdcS179D-hPRL comprovados por reação de PCR e análise por restrição como descrito abaixo.

\subsubsection{Construção do vetor p658-S177D-mPRL}

A construção utilizando o vetor p658 que possui poucos sítios de clonagem foi a que gerou mais dificuldades técnicas, exigindo maiores cuidados, demandando por conta disso um maior tempo para ser concluída. Parte das dificuldades encontradas se deve ao fato de realizarmos essa construção a partir do vetor p658-hPRL, sendo portanto necessário substituir o gene da hPRL pelo do antagonista de camundongo. O fato de o vetor apresentar dois sítios de restrição para a enzima BamHI causou mais dificuldades. A estratégia da tripla ligação foi realizada sem sucesso, mesmo utilizando diferentes proporções dos fragmentos. Entre as opções de construção, a que obteve êxito foi aquela baseada na digestão com a enzima HindIII, seguida por digestão parcial do vetor com a enzima BamHI. Retiramos dessa forma o gene correspondente ao cDNA da hPRL, para substituí-lo pelo cDNA do S177D-mPRL. Entre as dificuldades encontradas é importante destacar, com o objetivo de facilitar trabalhos futuros, a atividade residual da enzima BamHI, que mesmo após a purificação dos fragmentos, continuava ativa. Possivelmente esse fato impossibilitava a ação da enzima T4 DNA ligase. A inativação por adição de EDTA também não funcionou. Para eliminar de forma mais eficiente a enzima BamHI e também obter os fragmentos de DNA mais puros, resolvemos purificar tanto o vetor como o inserto por eletroforese em gel de poliacrilamida (PAGE). Utilizando esses fragmentos de DNA a reação de ligação funcionou muito bem, gerando 350 clones (3 placas). Os controles contendo na reação de ligação "só vetor" e "só inserto" resultaram em apenas 23 e 3 clones, respectivamente.

Para verificar se a construção estava correta foi realizada uma varredura com uma reação de PCR específica para o gene da $\mathrm{mPRL}$, utilizando como amostras DNA de bactérias coletadas das colônias obtidas da reação de ligação (FIG. 26). Verificamos que todos os 6 clones analisados apresentaram a sequência da mPRL. Para confirmação da construção foi realizada também a análise de restrição do DNA plasmidial extraído dos clones positivos (FIG. 27A). O 
DNA do antagonista S177D-mPRL possui sítio de restrição intragene para a enzima Xhol que pode gerar fragmentos de 365 pb e 334 pb, e não possuem para a enzima Xbal, portanto na presença dessa enzima o cDNA correspondente ao S177D-mPRL permanece integro, com 699 pb. Caso haja contaminação com o plasmídeo da hPRL, na análise com a enzima de restrição Xbal, teremos quebra do fragmento de 699 pb. Observamos na FIG. 27 que os clones 1, 2, 3 e 5 estão corretos, ou seja, apresentam o DNA do S177D-mPRL pois quando digeridos com Xbal apresentaram um fragmento e quando digeridos com Xhol apresentaram dois fragmentos. Foi escolhido o clone 1 para extração do DNA plasmidial p658S177D-mPRL (maxiprep) e a realização da transfecção das células de mamíferos.

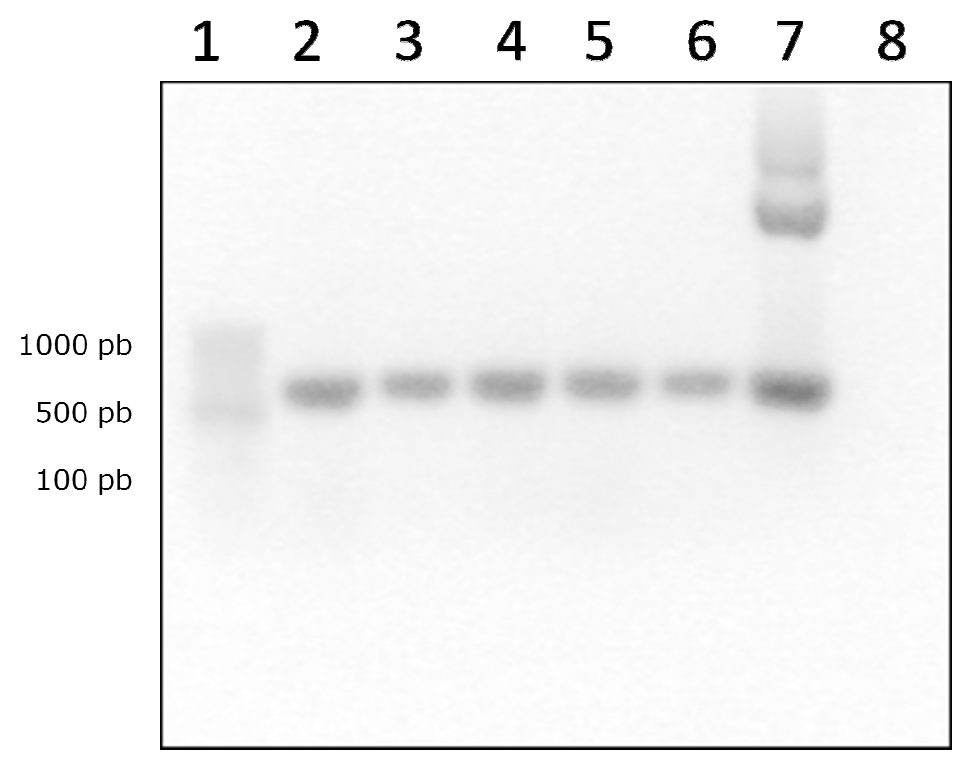

FIGURA 26. Eletroforese em gel de agarose 1\%, revelado por brometo de etídio, apresentando os fragmentos amplificados após PCR das colônias suspeitas de conter o plasmídeo p658-S177D-mPRL. (1) Marcador de massa molecular em número de pares de bases (pb), "Gene ruler Ladder 100 pb" (500 ng), (2) a (6) PCR de colônias bacterianas obtidas da reação de ligase (7) PCR com o pUC57S177D-mPRL, controle positivo e (8) PCR com o p658-hPRL, controle negativo (os primers são específicos para o gene da mPRL). 


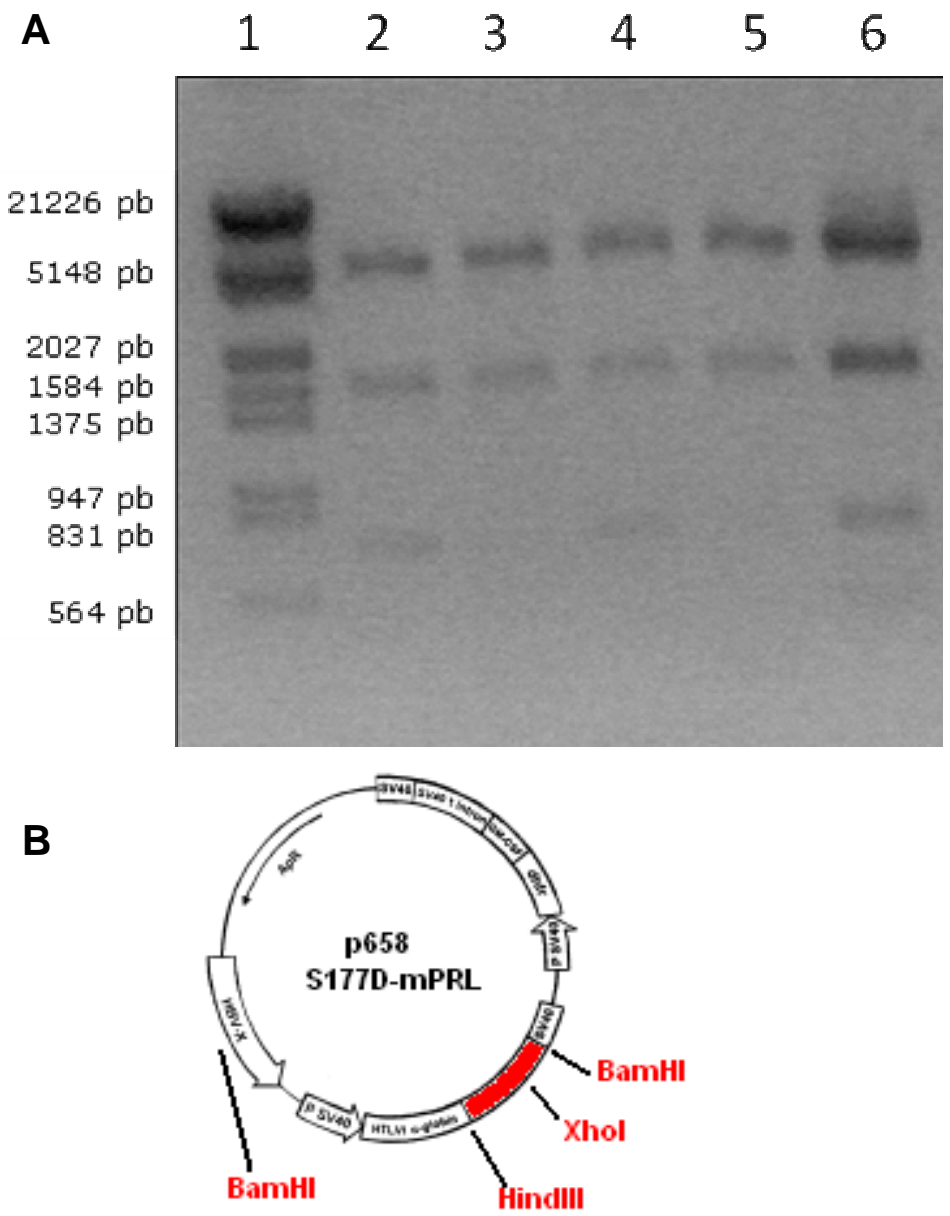

\section{FIGURA 27}

A. Eletroforese em gel de agarose $1 \%$, revelado por brometo de etídio, dos plasmídeos p658-S177D-mPRL após digestão com as enzimas de restrição BamHI, Hindlll e Xbal ou Xhol. A enzima Xbal não digere o gene da mPRL, mas digere o da hPRL. É útil para detectar contaminação por hPRL.

(1) Marcador de massa molecular em número de pares de bases (pb), 500ng de Lambda DNA completamente digerido com EcoRI e HindIII;

(2) Clone $1+$ BamHI + HindllI + Xbal - fragmento de $699 \mathrm{pb}$;

(3) Clone $2+$ BamHI + Hindlll + Xhol - fragmentos de $365 \mathrm{pb}+334 \mathrm{pb}$;

(4) Clone $3+\mathrm{BamHI}+$ HindllI + Xbal - fragmento de $699 \mathrm{pb}$;

(5) Clone $5+$ BamHI + Hindlll + Xhol - fragmentos de $365 \mathrm{pb}+334 \mathrm{pb}$;

(6) p658-hPRL + BamHI + Hindlll + Xhol - fragmento de $699 \mathrm{pb}$.

B. Mapa esquemático do vetor p658-S177D-mPRL. 


\subsubsection{Construção do vetor pEDdc-S177D-mPRL}

O esquema de construção do vetor pEDdc-S177-mPRL está apresentado em detalhes no capítulo materiais e métodos. Basicamente, o gene do antagonista foi retirado do vetor pUC57 com a enzima Xbal e introduzido no pEDdc linearizado com a mesma enzima. A maior dificuldade foi desfosforilar de forma eficiente o vetor linearizado, minimizando as chances do mesmo fechar sem o inserto. Também tivemos dificuldades na reação de ligação, provavelmente devido à ação residual da enzima fosfatase alcalina e/ou do seu tampão. A solução encontrada foi precipitar com etanol os fragmentos de DNA utilizados na reação de ligação, antes da adição da enzima de ligação e do tampão correspondente. O número de clones obtidos derivados da reação de ligação foram 65, enquanto o controle resultou em 4 clones.

Como na construção do p658-S177D-mPRL, realizamos também uma varredura por PCR específico para o gene da mPRL. Analisamos 8 colônias de bactérias retiradas diretamente da placa de reação, os resultados são apresentados na FIG. 28. Dos 8 clones analisados, 6 estavam corretos - clones 1, 2, 3, 4, 6 e 8, já que houve amplificação do fragmento indicando a presença do plasmídeo pEDdc-S177D-mPRL.

Os clones positivos foram utilizados para extração do DNA plasmidial (miniprep) e análise, com enzimas de restrição, para confirmar a correta posição do inserto, conforme podemos observar na FIG. 29. Como as duas extremidades do inserto foram digeridos com Xbal, havia 50\% de chance do inserto se ligar na orientação correta e $50 \%$ de se ligar na orientação oposta. Dos 6 clones analisados, 4 estavam corretos - clones 1,3, 4, 6, já que a digestão com a enzima EcoRI, um sítio interno ao inserto S177D-mPRL e outro no vetor pEDdc, resultou no fragmento esperado de $550 \mathrm{pb}$. O clone 3 foi escolhido para amplificação do plasmídeo (maxiprep) e realização da transfecção em células de mamíferos. 


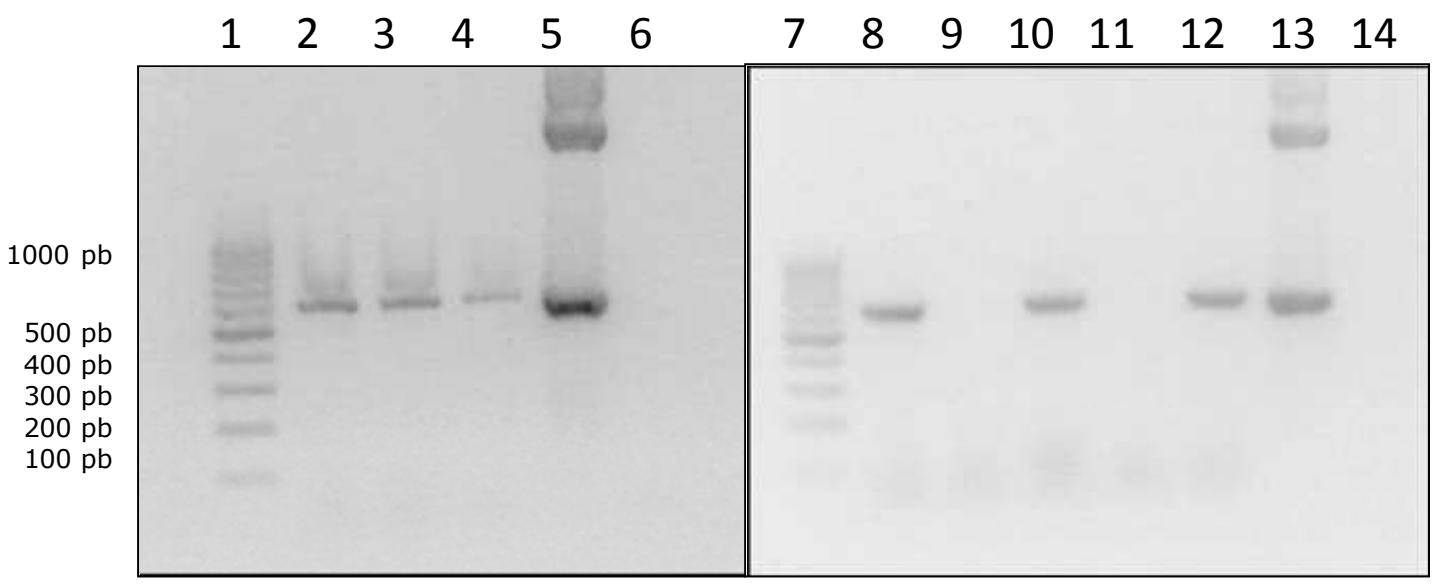

FIGURA 28. Eletroforese em gel de agarose 1\%, revelado por brometo de etídio, apresentando os fragmentos amplificados após PCR, utilizando primers internos ao gene da mPRL, para analisar as colônias suspeitas de conter o plamídeo pEDdc-S177D-mPRL.

(1) Marcador de massa molecular em número de pares de bases (pb), "Gene ruler Ladder 100 pb" (500 ng);

(2) Clone 1-correto;

(3) Clone 2 - correto;

(4) Clone 3 - correto;

(5) pUC57-S177D-mPRL (controle positivo);

(6) p658-hPRL (controle negativo);

(7) Marcador de massa molecular em número de pares de bases (pb), "Gene ruler Ladder 100 pb" (500 ng);

(8) Clone 4-correto;

(9) Clone 5 - sem o inserto;

(10) Clone 6 - correto;

(11) Clone 7 - sem o inserto;

(12) Clone 8 - correto;

(13) pUC57-S177D-mPRL (controle positivo);

(14) p658-hPRL (controle negativo). 
A

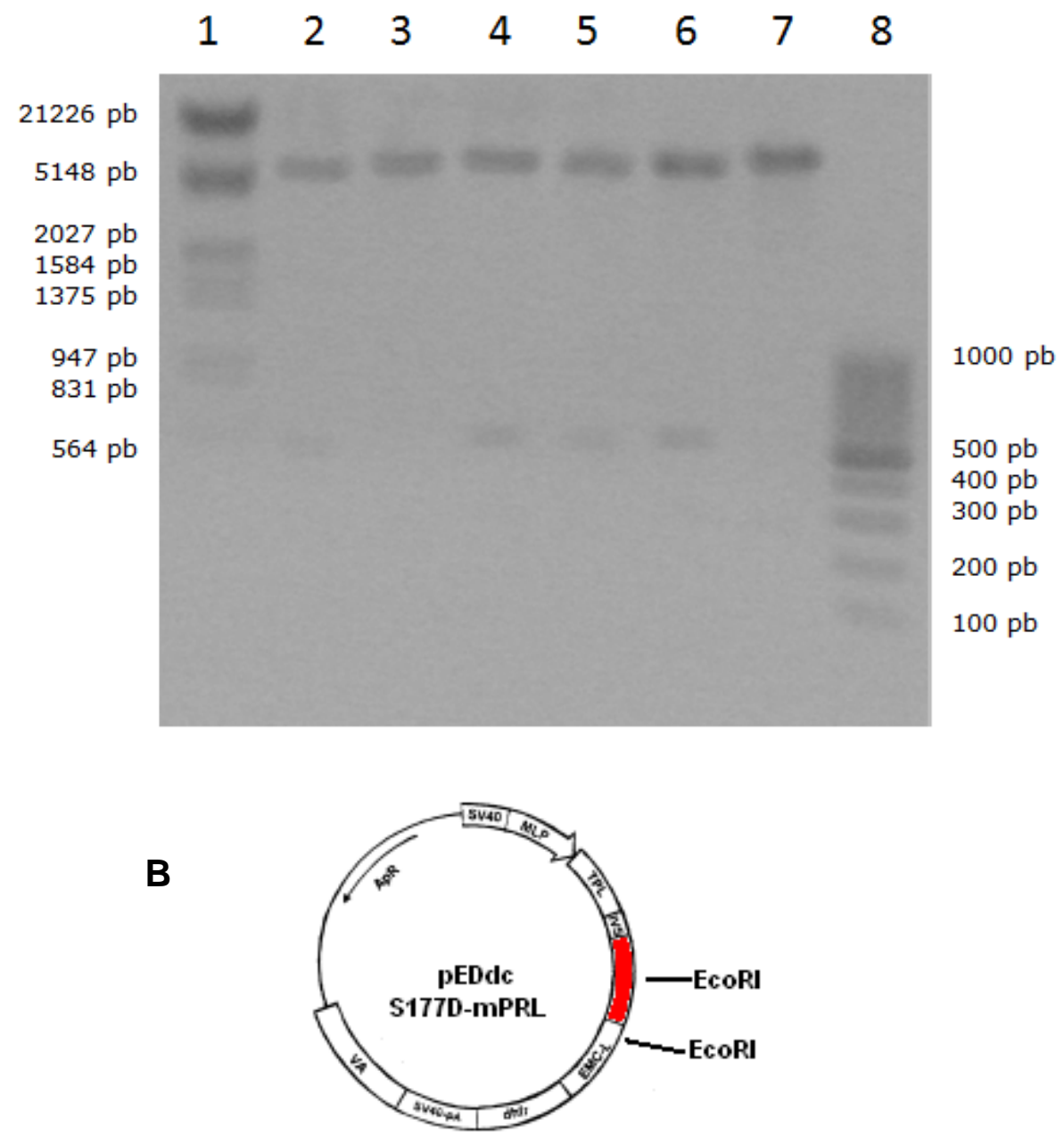

FIGURA 29. Eletroforese em gel de agarose 1\%, revelado por brometo de etídio, apresentando os fragmentos dos plamídeos digeridos com a enzima de restrição EcoRI das minipreps das colônias contendo o pEDdc-S177D-mPRL. O inserto na posição correta resulta em fragmento de $\sim 550 \mathrm{pb}$.

(1) Marcador de massa molecular em número de pares de bases (pb), $500 \mathrm{ng}$ de Lambda DNA completamente digerido com EcoRI e HindIII;

(2) Clone 1- correto;

(3) Clone 2 - invertido;

(4) Clone 3- correto;

(5) Clone 4- correto;

(6) Clone 6- correto;

(7) Clone 8 - invertido;

(8) Marcador de massa molecular em número de pares de bases ( $\mathrm{pb})$, "Gene ruler Ladder 100 pb" (500 ng). 


\subsection{Expressão do antagonista S177D-mPRL em células de mamíferos}

\subsubsection{Transfecção transiente em células CHO-K1 e COS-7}

A expressão transiente do antagonista S177D-mPRL em células de mamíferos $\mathrm{CHO}-\mathrm{K} 1$ e COS-7 foi realizada em placas de 24 poços, semeadas com 50.000 células/poço/500 $\mu \mathrm{L}$ de meio. As células foram transfectadas utilizando Lipofectamine $^{\mathrm{TM}}$. Com o objetivo de determinar a melhor condição para uma transfecção mais eficiente, células $\mathrm{CHO}-\mathrm{K} 1$ foram transfectadas com o plasmídeo pEDdc-S177D-mPRL com 3 concentrações de Lipofectamine $^{\mathrm{TM}}$ : 1, 2 e $3 \mu \mathrm{L}$ por poço. Após 72 horas da transfecção, o meio a-MEM com 10\% de SFB foi coletado e analisado por WB. Na análise direta do meio de cultura observamos que a transfecção com $1 \mu \mathrm{L}$ Lipofectamine ${ }^{\mathrm{TM}}$ foi mais eficiente, pois observamos um melhor crescimento celular na placa e uma expressão maior comparando as bandas reveladas por WB. (FIG. 30, amostra 2). O meio de cultura quando aplicado não apresentou nenhuma banda (dados não mostrados).

Pela primeira vez, portanto, foi detectada a presença do antagonista S177D-mPRL sintetizada em células de mamífero.

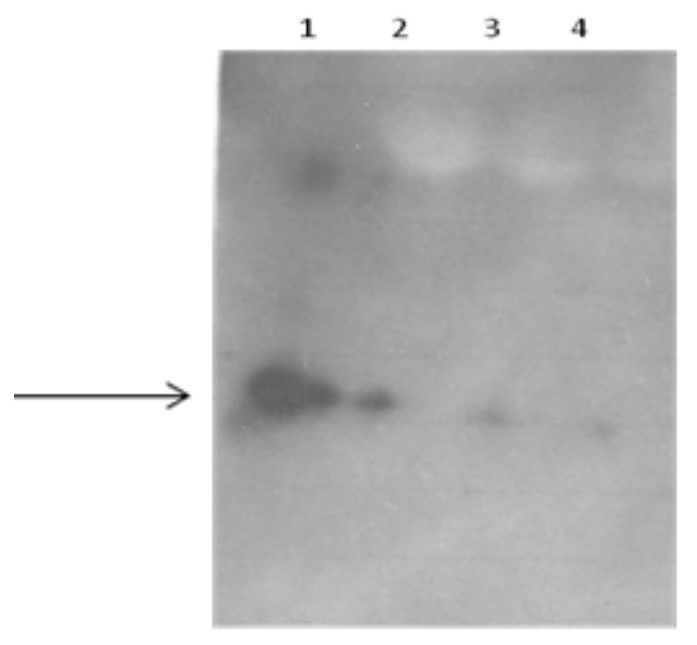

Figura 30. WB comparando amostras de meio de células CHO-K1 (20 $\mu \mathrm{L}), 72 \mathrm{~h}$ após a transfecção com os plasmídeos pEDdc-S177D-mPRL na presença de diferentes quantidades de Lipofectamine TM. (1) padrão r-met-mPRL, 90 ng (22,5 kDa); (2) Meio da transfecção com $1 \mu \mathrm{L}$ Lipofectamine $^{\mathrm{TM}}$; (3) Meio da transfecção com $2 \mu \mathrm{L}$ Lipofectamine ${ }^{\mathrm{TM}}$; (4) Meio da transfecção com $3 \mu \mathrm{L}$ Lipofectamine $^{\mathrm{TM}}$. Foi utilizado soro anti-mPRL. A seta indica a posição da r-met-mPRL. 
Realizamos outro estudo com transfecção transiente utilizando células COS-7. As amostras do lisado de células COS-7 após 72 h da transfecção foram analisadas por WB (FIG. 31). Observamos a expressão do S177D-mPRL tanto nas células transfectadas com o plasmídeo pEDdc-S177D-mPRL como nas transfectadas com p658-S177D-mPRL. Por se tratar de lisado celular, podemos observar tanto a forma esperada da proteína como outras bandas, talvez correspondentes às formas agregadas ou proteínas clivadas, ou ainda com peptídeo sinalizador.

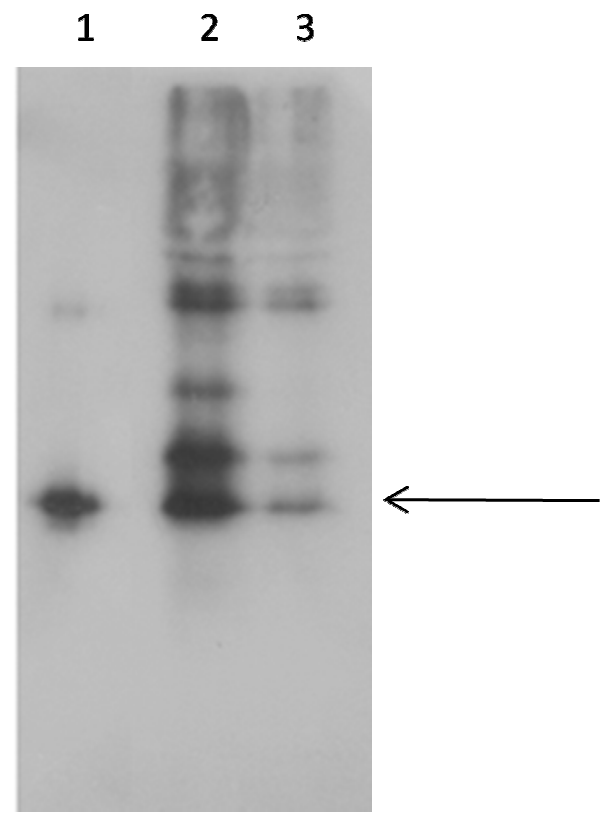

FIGURA 31. WB do lisado de células COS-7, 72 horas após a transfecção com os plasmídeos pEDdc-S177D-mPRL e p658-S177D-mPRL, utilizando $1 \mu \mathrm{L}$ de Lipofectamine $^{\mathrm{TM}}$ em placas de 24 poços, 2 dias após serem semeadas com 50.000 células. (1) padrão r-met-mPRL 54 ng; (2) $20 \mu \mathrm{L}$ da suspensão de células transfectadas com o vetor pEDdc-S177DmPRL; (3) $20 \mu \mathrm{L}$ da suspensão de células transfectadas com o vetor p658-S177D-mPRL. As células foram tripsinizadas, ressuspendidas em PBS na concentração de $10^{6}$ células $/ \mathrm{mL}$, adicionado tampão de amostra e fervidas. Foi utilizado soro anti-mPRL. A seta indica a posição da r-met-mPRL.

É interessante observar que o vetor pEDdc-S177D-mPRL proporcionou uma expressão maior em relação ao p658-S177D-mPRL quando analisado o lisado celular. Talvez o local de integração do gene ou a eficiência do promotor tenham contribuído para essa diferença de expressão. Observamos também que 
o meio de cultura coletado e analisado por WB não revelou nenhuma banda. Estimamos, assim, que a secreção de S177D-mPRL tenha sido inferior a 0,25 $\mu \mathrm{g} / \mathrm{mL}$, ou seja, abaixo do nível de detecção do WB que é de $\sim 5 \mathrm{ng}$.

\subsubsection{Transfecção permanente em células $\mathrm{CHO}$ dhfr-}

As células $\mathrm{CHO}$ dhfr- (mutante DXB11) foram utilizadas para transfecção permanente com os plasmídeos pEDdc-S177D-mPRL e p658-S177D-mPRL. Após a transfecção em placas de 24 poços, as células foram tripsinizadas e semeadas em placas de $10 \mathrm{~cm} \varnothing$ em meio alfa MEM, 10\% SFB dialisado, com antibióticos, iniciando assim o processo de seleção.

Após 10 dias da transfecção, foram isolados 24 clones das células $\mathrm{CHO}$ p658-S177D-mPRL e semeados em placas de 24 poços. Após 2 semanas, os clones confluentes foram semeados em placas de $10 \mathrm{~cm} \varnothing$ e após ser atingida nova confluência ( uma semana) o meio de seleção foi substituído por CHO-SSFM II, sem SFB. Após $24 \mathrm{~h}$ o meio condicionado de cada clone foi coletado para posterior análise por dot blot e WB (FIG. 32 e 33). Os clones foram congelados em criotubos e armazenados em nitrogênio líquido.

As células CHO-pEDdc-S177D-mPRL atingiram a confluência na placa de 24 poços. Em seguida foram transferidas para uma placa de $10 \mathrm{~cm} \varnothing$ para início da etapa de amplificação gênica com metotrexato (MTX). Após 14 dias, as células foram submetidas a um aumento gradual do MTX até uma concentração de 50 nM MTX. O meio de cultura condicionado (24h) foi separado para análises de expressão e as células foram congeladas. É importante lembrar que até esta fase os clones mais produtivos dessa construção ainda não foram isolados. Esse trabalho será realizado futuramente. 


\subsubsection{Análise de expressão dos clones}

O meio condicionado após a fase de seleção de cada um dos 24 clones de células CHO dhfr- transfectadas com o vetor p658-S177D-mPRL foi avaliado por dot blot seguido por WB. A técnica do dot blot se mostrou uma técnica rápida e prática para comparar os níveis de expressão dos diferentes clones. Apresenta a vantagem de possibilitar a aplicação de maiores volumes de meio de cultura, sem tratamento prévio, aumentando assim a sensibilidade de detecção pelo WB. A sua limitação principal é a avaliação qualitativa da proteína de interesse. O resultado dessa análise está apresentado na FIG. 32. O clone 12, com melhor expressão, foi selecionado para análise por WB (FIG. 33). É interessante ressaltar que o meio condicionado foi aplicado e a proteína foi detectada, sem necessidade de concentração, após a seleção dos clones por 25 dias.

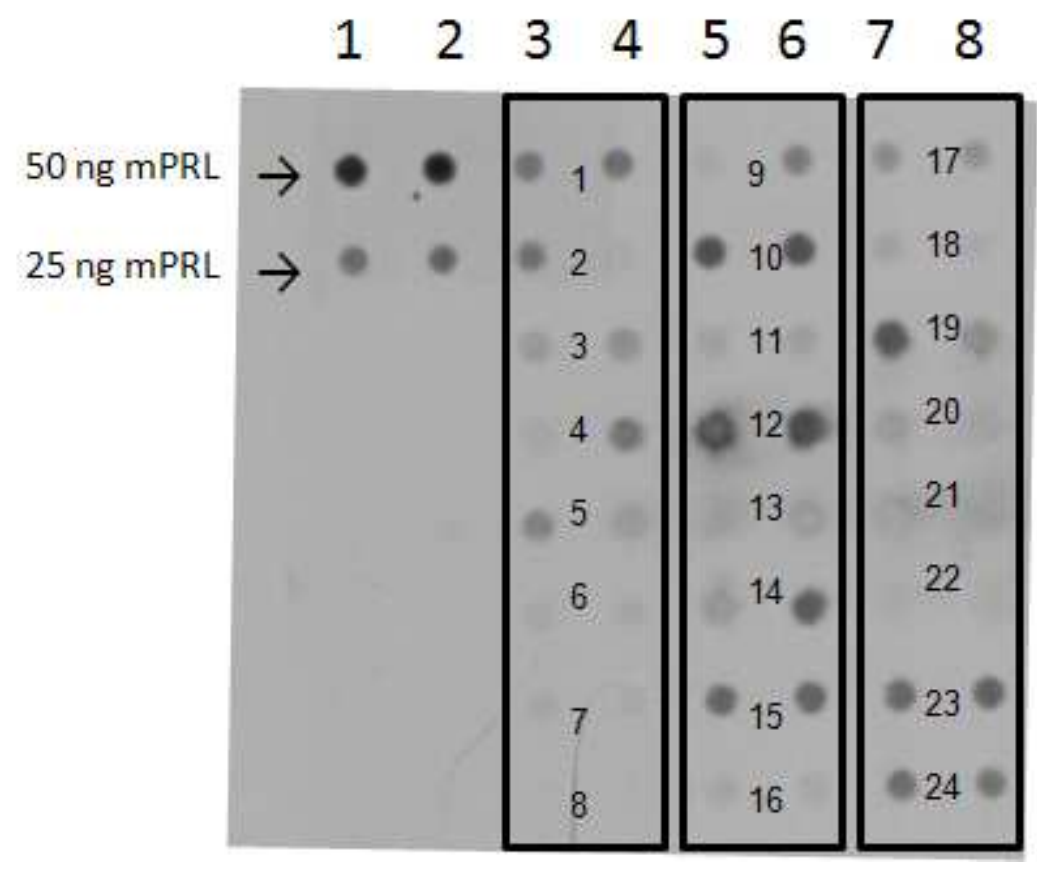

FIGURA 32. Dot blot e WB do meio condicionado (100 $\mu \mathrm{L}$ da coleta de $24 \mathrm{~h}$ com meio CHO-SFM II) de células $\mathrm{CHO}$ dhfr- (mutante DXB11) transfectadas com 0 plasmídeo p658-S177D-mPRL, 25 dias após a seleção com meio $\alpha$-MEM suplementado com 10\% SFBd e antibióticos. Análise em duplicata. 
Observamos na FIG. 33 que o meio condicionado continha S177D-mPRL representado por uma banda única na mesma posição da r-met-mPRL. Analisando as FIG. 32 e 33 e considerando o volume de meio aplicado, estimamos uma expressão do antagonista secretado pelo clone 12 da ordem de 1 $\mu \mathrm{g} / \mathrm{mL}$ de meio, quando comparamos com a intensidade do padrão r-met-mPRL.

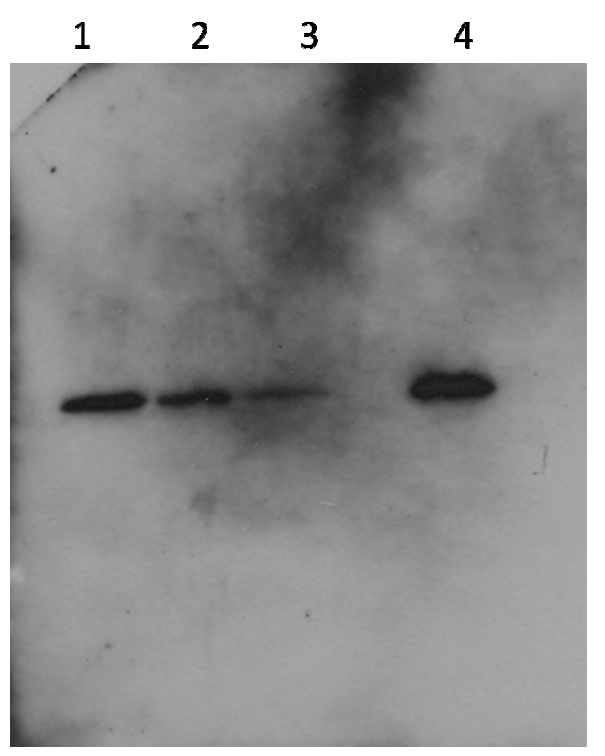

FIGURA 33. WB da amostra de meio condicionado da cultura de células $\mathrm{CHO}$ p658-S177D-mPRL, clone 12, após SDS-PAGE em condições redutoras. Foi utilizado soro anti-mPRL. (1), (2) e (3) r-met-mPRL $50 \mathrm{ng} ; 25 \mathrm{ng}$ e 12,5 ng, respectivamente. (4) S177D-mPRL (200 $\mu \mathrm{L}$, concentrado por precipitação com TCA).

A amostra do meio condicionado das células CHO-pEDdc-S177D-mPRL (50 nM MTX) também foi analisada por dot blot/WB e por SDS-PAGE/WB (FIG. 34 e 35). A avaliação preliminar do meio condicionado das células CHO-pEDdcS177D-mPRL quando analisamos as FIG. 34 e 35, considerando o volume de meio aplicado, estimamos uma expressão da ordem de $0,5 \mu \mathrm{g} / \mathrm{mL}$ de meio quando comparamos com a intensidade do padrão r-met-mPRL.

Considerando que os clones ainda não foram isolados e que o processo de amplificação gênica não terminou, faltando testar concentrações maiores de MTX (até $10 \mu \mathrm{M}$ ). É esperado que a construção com o pEDdc-S177D-mPRL gere clones com bons níveis de expressão. 


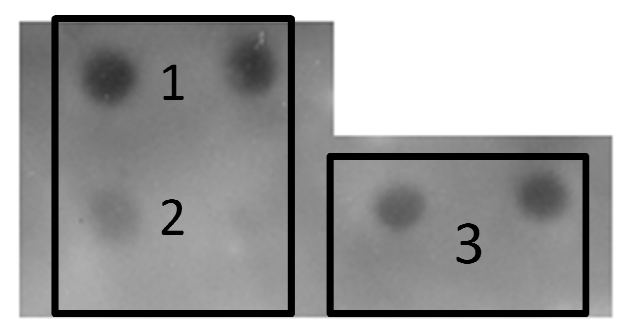

FIGURA 34. Dot blot e WB para análise do meio condicionado (100 $\mu \mathrm{L}$ da coleta 24 h com meio CHO-S-SFM II) do "pool" de células CHO-pEDdc-S177D-mPRL. Análise em duplicata: (1) r-met-mPRL (50 ng); (2) r-met-mPRL (17 ng); (3) meio condicionado da etapa de amplificação realizada com 50 nM MTX.

\section{2}

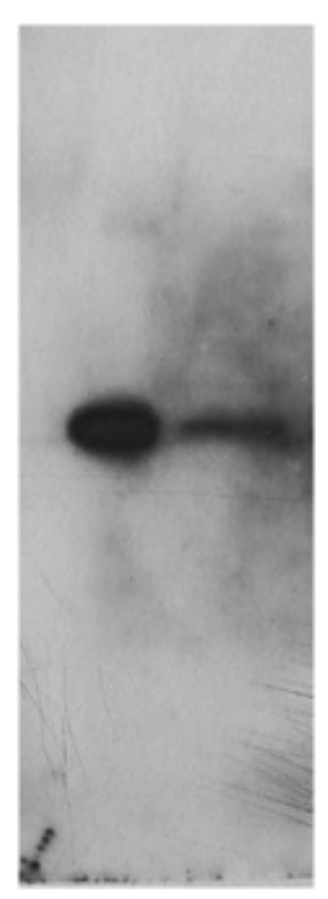

FIGURA 35. WB, após SDS-PAGE em condições redutoras, da amostra de meio condicionado (24 h) da cultura de células CHO-pEDdc-S177D-mPRL. (1) r-metmPRL (50 ng), (2) meio após amplificação com 50 nM MTX (50 $\mu \mathrm{L}$, concentrado por precipitação com TCA). Foi utilizado soro anti-mPRL.

Como atividades futuras, portanto, faz-se necessária uma avaliação mais precisa da expressão de cada clone e caracterização do antagonista S177DmPRL sintetizado. 


\section{DISCUSSÃO}

A mPRL foi expressa pela primeira vez no periplasma bacteriano, com nível de expressão de $0,1 \pm 13,2 \% \mu \mathrm{g} / \mathrm{mL} / \mathrm{A}_{600}$. Em nosso laboratório, o mesmo cassete de expressão, contendo o promotor $\lambda \mathrm{PL}_{\mathrm{L}}$ e o peptídeo sinalizador DsbA, introduzido também na cepa W3110 se mostrou bem mais eficiente na expressão do hGH e da hPRL, com expressões específicas de $3,9 \pm 16,3 \%$ e $0,92 \pm 0,10 \%$ $\mu \mathrm{g} / \mathrm{mL} / A_{600}$, respectivamente (Soares e col., 2003; Soares e col., 2008). No caso da hPRL, é importante salientar que com a utilização do repressor clts e a necessária incubação a $42^{\circ} \mathrm{C}$, a expressão periplásmica da $\mathrm{hPRL}$ foi de somente $0,03 \mu \mathrm{g} / \mathrm{mL} / A_{600}$. Para incrementar os níveis de expressão foi utilizado o artifício de retirar o repressor, e por consequência $0 \lambda P_{L}$ passou a funcionar como promotor constitutivo, possibilitando o cultivo em temperaturas menores, como $37^{\circ}$ C. Essa condição reduz a provável degradação da hPRL que ocorre enquanto esse hormônio está presente no citoplasma bacteriano, aumentando assim os rendimentos de expressão. Infelizmente, a mPRL parece ser mais susceptível à degradação no citoplasma que a hPRL, pois a sua expressão nas mesmas condições foi aproximadamente dez vezes menor.

Embora com expressão relativamente baixa, realizamos uma fermentação em biorreator seguindo condições previamente estabelecidas para a produção de hPRL. A curva de crescimento foi bem parecida (FIG. 20) e foi obtida uma produção volumétrica próxima a $2,5 \mu \mathrm{g} / \mathrm{mL}$, se considerarmos o T5 da fermentação. No T6 ocorreu uma queda na produção, indicando que a fermentação poderia ter sido encerrada antes. Consideramos esta produtividade útil, do ponto de vista laboratorial.

Com o fluido periplásmico proveniente da fermentação foi possível padronizar um novo processo de purificação, em duas etapas: concentração e purificação por hidrofobicidade (resina Phenyl Sepharose CL-4B) seguida por HPLC de fase reversa. Um aspecto importante nesse processo de purificação, que claramente pode ser aperfeiçoado, foi a eficiência da coluna C4 (Vydac) de fase reversa, utilizada nesse caso como coluna preparativa. Apresentou altos 
rendimentos e um excelente fator de purificação. É importante destacar que com o uso da acetonitrila como fase móvel, diferente do que ocorre com n-propanol, praticamente não houve agregação da $\mathrm{mPRL}$, como podemos observar comparando as FIG. 17 e 23.

A obtenção da mPRL autentica pura é importante, pois a mesma pode ser utilizada como referência interna nos nossos vários ensaios (Nb2, HPLC, WB, etc) relativos a experimentos em camundongos. A comparação com o padrão de mPRL da NIH, com metionina foi interessante. Observamos diferença significativa ( 5 min) no tempo de retenção, na análise por RP-HPLC devida somente à presença da metionina inicial (TAB. 4). No bioensaio com células $\mathrm{Nb2}$, a potência biológica avaliada para a $\mathrm{MPRL}$ recombinante produzida no IPEN foi de 33,9 $\pm 1,4$ $\mathrm{UI} / \mathrm{mg}$, maior que a potência da mPRL (NIH/NIDDK), calculada em 20,4 $\pm 2,1$ Ul/mg. Essa diferença também pode ser resultante de perda da atividade no processo de refolding (enovelamento), liofilização e reconstituição da r-met-mPRL produzida em corpos de inclusão no citoplasma. De qualquer forma, tanto a $\mathrm{mPRL}$ quanto a r-met-mPRL apresentaram potência biológica bem menores do que da r-hPRL, produzida pelo IPEN também no espaço periplásmico de $E$. coli, $51,5 \pm 24,1 \mathrm{Ul} / \mathrm{mg}$ (Soares e col., 2008). A maior atividade biológica da hPRL com relação à $\mathrm{mPRL}$, no ensaio com células $\mathrm{Nb2}$, também já foi relatado por Utama $\mathrm{e}$ col. (2009). O curioso é que, considerando que as células $\mathrm{Nb} 2$ são derivadas de linfoma de rato, a $\mathrm{mPRL}$ mesmo sendo mais parecida com a prolactina de rato (84\% de identidade) do que a hPRL (62\% de identidade), apresenta uma atividade biológica bem menor. Ressaltamos também que o NIH (EUA) poderia estar interessado na nossa mPRL autêntica purificada sendo que no passado o responsável do setor (Dr. Parlow) já nos contatou a este propósito.

Ainda com relação ao ensaio biológico é interessante o fato da $\mathrm{mPRL}$, no ensaio com células Ba/F3-LLP apresentar uma potência de apenas 2,42 \pm 0,38 $\mathrm{UI} / \mathrm{mg}$. Essa baixa potência se justifica porque essas células de camundongos pro-B Ba/F3-LLP apresentam receptores para $\mathrm{hPRL}$, com afinidade bem menor para a mPRL, como já relatado por outros autores (Utama e col., 2006; 2009). Essa baixa atividade da $\mathrm{mPRL}$ em células com receptores para $\mathrm{hPRL}$ merece algumas considerações. Utama e col. (2006) demonstraram que a mPRL é um fraco agonista para receptores de hPRL. Assim, modelos animais utilizando camundongos com tumores humanos apresentam limitações quando se avalia o 
desenvolvimento desses tumores em comparação com os mesmos tumores em humanos. Por exemplo, a ação de antagonistas para receptores de hPRL no tratamento de câncer de mama. Esses antagonistas humanos teriam um efeito alterado devido a ausência do agonista, mesmo no caso de produção de hPRL autócrina no estudo de tumores humanos em camundongos. Utama e col. (2009) afirmam também que a $\mathrm{mPRL}$ funciona como um parcial antagonista de receptor de $h P R L$, pois a $M P R L$ compete com a $h P R L$ na ligação ao receptor, produzindo uma baixa resposta.

No caso da expressão do análogo S177D-mPRL em E. coli a baixa expressão foi ainda mais gritante não atingindo níveis suficientes para viabilizar uma fermentação em biorreator. Como já mencionado anteriormente, expressões baixas também foram observadas por nós no caso do antagonista S179D-hPRL. Naquela oportunidade, na tentativa de melhorar a expressão, foi refeita a construção do gene do antagonista S179D-hPRL utilizando um outro códon (GAT) responsável pela introdução do ácido aspártico na posição 179, cuja frequência de uso pela E. coli é de $59 \%$, enquanto que o códon utilizado na primeira construção (GAC) apresenta uma freqüência menor, 41\%. (http://www.sci.sdsu.edu/ smaloy/MicrobialGenetics/topics/in-vitro-genetics/codon-usage.html).

Porém nenhuma melhora na expressão foi observada. Também foram testadas diferentes cepas de E. coli como: BL21 (protease deficiente); BL21 starß (com mutação no gene da RNAse); BL21 codonplus® (capaz de reconhecer códons raros; AD494 (mutante trxB que facilita o "folding" citoplásmico) e BL21 (trxB) (que associa as características de protease deficiente e ambiente redutor citoplasmático) e não foram observados aumentos significativos na expressão desse antagonista. No estudo atual testamos a cepa Rosetta-gami B ${ }^{T M}$, que contém tRNAs de códons raros em E. coli, também sem aumento na expressão. É interessante como a troca de apenas um aminoácido pode alterar tão significativamente a expressão dessa proteína. Isto é provavelmente devido às alterações estruturais na proteína, também responsáveis pela esperada ação antagonista resultante de uma diferente cascata de sinalização intracelular (Soares e col., 2006; Ueda e col., 2009). A análise do lisado bacteriano (FIG. 18) indica que provavelmente as enzimas proteolíticas presentes no citoplasma bacteriano da nossa cepa agiram sobre o antagonista S177D-mPRL, mesmo a 30 C, tornando inviável a expressão dessa proteína no nosso modelo. 
Outra opção para expressão em bactéria seria a retirada do peptídeo sinal para expressão da proteína no citoplasma. Porém, a $\mathrm{mPRL}$ apresentaria assim uma metionina inicial (sequência não autêntica) e o enovelamento correto da molécula (refolding) deverá ser obtido por meio de tratamento físico-químico (Chura-Chambi e col., 2008). É importante lembrar que a r-met-mPRL já foi sintetizada no citoplasma bacteriano (Yamamoto e col., 1992), encontrando também dificuldades. Os autores conseguiram sucesso na expressão somente após substituírem os primeiros 31 códons após o ATG por uma sequência de nucleotídeos rica em AT, sem mudar a sequência de aminoácidos.

A expressão de proteínas heterólogas em E. coli, tanto na forma de corpos de inclusão como na forma solúvel, seja no citoplasma ou no periplasma, tem sido largamente utilizada devido ao seu menor custo quando comparado à expressão em sistemas eucarióticos. Porém, devida a expressão extremamente baixa em bactérias do S177D-mPRL e considerando os nossos resultados positivos na expressão do antagonista S179D-hPRL e de outras proteínas em células $\mathrm{CHO}$, optamos por tentar expressar o antagonista nesse hospedeiro.

Após a confirmação da correta sequência dos dois vetores para células CHO dhfr-, o p658-S177D-mPRL e o pEDdc-S177D-mPRL, cuja complexa construção atrasou consideravelmente 0 nosso cronograma, realizamos inicialmente uma transfecção transiente para confirmar a expressão da proteína de interesse. De fato a expressão do antagonista foi confirmada para os dois vetores após análise por SDS-PAGE/WB. No entanto, nas células COS-7 transfectadas, a visualização só foi possível quando foi analisado o lisado celular (FIG. 31). Como a sensibilidade do WB está em torno de 5 ng, e considerando que foram analisados $20 \mu \mathrm{L}$ acreditamos que a expressão transiente tenha sido inferior a 0,25 $\mu \mathrm{g} / \mathrm{mL}$. Esperávamos uma expressão transiente maior no meio condicionado, pois há relatos na literatura que a expressão transiente em células de mamíferos (células HEK293E) pode atingir níveis tão elevados quanto 1 $\mathrm{mg} / \mathrm{mL}$ (Backliwal e col., 2008).

O clone 12, resultante da transfecção permanente com o vetor p658S177D-mPRL apresentou expressão de $\sim 1 \mu \mathrm{g}$ de S177D-mPRL/mL/dia no meio de cultura em placas com células aderidas, cultivadas em meio CHO-S-SFM II e sem SFB. Embora esse valor necessite de confirmação, é um resultado bastante importante. Em estudos recentes em nosso grupo, com as células $\mathrm{CHO}$ 
adaptadas ao crescimento em suspensão e produtoras de hPRL, obtivemos com esse mesmo meio $6 \mu \mathrm{g}$ de $\mathrm{hPRL} / \mathrm{mL} /$ dia (Arthuso e col., submetido para publicação).

O estudo da expressão do antagonista em células $\mathrm{CHO}$ dhfr- transfectadas com o vetor pEDdc-S177D-mPRL ainda não foi concluído. Estamos isolando os clones e concluindo a amplificação gênica. Normalmente, pela nossa experiência, achamos melhor fazer a seleção dos clones antes da amplificação gênica. Nesse caso, porém, devido ao fato de não termos ainda padronizado um imunoensaio sensível e específico para mPRL optamos por realizar as primeiras etapas da amplificação gênica, até 50 nM de MTX, sem selecionar clones. Os resultados de expressão do meio condicionado do "pool de clones", mesmo ainda grosseiros, indicam uma produtividade volumétrica da ordem de 0,5-1 $\mu \mathrm{g} / \mathrm{mL}$. A técnica do dot blot, seguido do WB se mostrou uma ferramenta importante e prática para avaliar comparativamente a produção de diferentes clones, funcionando bem como técnica para seleção dos melhores clones.

Embora a expressão do análogo/antagonista S177D-mPRL em células CHO não esteja totalmente concluída, os resultados obtidos até agora são bastante promissores. Consideramos que uma expressão do nível de $\sim 1 \mu \mathrm{g} / \mathrm{mL}$ já seja laboratorialmente útil, mas certamente os níveis de expressão poderão ser aumentados. Recentemente demonstramos que o uso do butirato de sódio aumenta a expressão da hPRL em células $\mathrm{CHO}$ de um fator 2 (Rodrigues Goulart e col., 2010). A produção e purificação do S177D-mPRL são alguns dos próximos desafios fundamentais para viabilizar o projeto de utilização desse antagonista em estudos com modelos animais. Um dado importante relacionado à purificação desse antagonista é o ponto isoelétrico (PI) da mPRL estimado em 5,26, enquanto o PI da hPRL é de 6,15. A técnica de purificação utilizada em nosso laboratório para a $\mathrm{hPRL}$ produzida por células $\mathrm{CHO}$ tem por primeira etapa a concentração e purificação parcial baseadas em uma resina de troca catiônica (SP - Sepharose Fast Flow), nesse processo o $\mathrm{pH}$ do meio condicionado é ajustado para 5,0, um valor muito próximo do PI da mPRL, podendo ocasionar a precipitação e perda do produto durante a purificação. Uma alternativa interessante pode ser a utilização do processo de purificação desenvolvido nesse trabalho aplicado à purificação da $\mathrm{mPRL}$ produzida por $E$. coli no qual foi utilizado 
concentração e purificação por hidrofobicidade (resina Phenyl Sepharose CL-4B) seguida por RP-HPLC.

Outras estratégias como mudança do peptídeo sinal, utilização de outros vetores de expressão, proteínas de fusão, inibidores de apoptose, entre outros, podem ser utilizados para obtermos uma maior expressão de mPRL e de S177D$\mathrm{mPRL}$, tanto em E. coli como em células de mamíferos. Esperamos, portanto, que os dados apresentados nesta tese possam contribuir e sejam utilizados já nos estudos que tenham como foco a influência da prolactina na gênese e evolução de doenças crônicas autoimunes com a utilização de camundongos como modelos animais. 


\section{CONCLUSÕES}

Foi realizada a caracterização do padrão de referência de r-met-mPRL (NIH/NIDDK) por SDS-PAGE, WB, RP-HPLC e HPSEC, assim como foi também avaliada sua atividade biológica em células Ba/F3-LLP e Nb2. Observamos que em comparação com o r-hPRL e o r-hGH, a r-met-mPRL apresenta uma hidrofobicidade menor. $\mathrm{Na}$ análise por SDS-PAGE, mostramos que é possível diferenciar a r-met-mPRL da r-hPRL. A potência biológica da $r$ met-mPRL foi menor que a da $r-h P R L$, sendo mais pronunciada em células $\mathrm{Ba} / \mathrm{F} 3-\mathrm{LLP}$ que em Nb2.

$\checkmark$ Foram obtidos os vetores para expressão da mPRL e S177D-mPRL no periplasma de Escherichia coli, utilizando o promotor $\lambda \mathrm{P}_{\mathrm{L}}$ e o peptídeo sinalizador DsbA.

$\checkmark$ Os níveis de expressão obtidos até agora para a mPRL atingiram 0,1 $\mu \mathrm{g} / \mathrm{mL} / \mathrm{A}_{600}$. Mesmo estando bem abaixo daqueles obtidos para a $\mathrm{hPRL}$ (aproximadamente 10 vezes menor) são suficientes para a realização dos estudos propostos.

$\checkmark$ A produção em biorreator da $\mathrm{mPRL}$ atingiu uma produtividade volumétrica de $2,5 \mu \mathrm{g} / \mathrm{mL}$, com biomassa de $\sim 25$ unidades $A_{600}$.

$\checkmark$ Foi desenvolvido um novo processo de purificação de mPRL, baseado na concentração e purificação em coluna Phenyl Sepharose CL-4B, seguida por RP-HPLC e HPSEC.

$\checkmark$ Os níveis de expressão obtidos para o análogo antagonista S177D-mPRL inviabilizaram a sua produção em E. coli.

$\checkmark$ Foram construídos os vetores pEDdc-S177D-mPRL e p658-S177D-mPRL para expressão em células de mamíferos.

$\checkmark$ A expressão do análogo antagonista em células $\mathrm{CHO}$ atingiu $\sim 1 \mu \mathrm{g} / \mathrm{mL} / \mathrm{dia}$ utilizando o vetor p658-S177D-mPRL em placas com $10^{6}$ células $/ \mathrm{mL}$. 
Está, portanto, aberto, pela primeira vez, o caminho para a realização de estudos em modelos homólogos, ou seja, com prolactina de camundongo e seu antagonista em camundongos. 


\section{REFERÊNCIAS BIBLIOGRÁFICAS}

ARAMBURO, C.; MONTIEL, J.L.; PROUDMAN, J.A.; BERGHMAN, L.R.; SCANES, C.G. Phosphorylation of prolactin and growth hormone. J Mol Endocrinol, v. 8, n. 3, p. 183-191, 1992.

BACKLIWAL, G.; HILDINGER, M.; CHENUET, S.; WULHFARD, S.; DE JESUS, M.; WURM, F.M. Rational vector design and multi-pathway modulation of HEK 293E cells yield recombinant antibody titers exceeding 1 $\mathrm{g} / \mathrm{l}$ by transient transfection under serum-free conditions. Nucleic Acids Res, v. 36, n. 15, p. e96, 2008.

BARTOLINI, P.; SOARES, C.R.J.; GOMIDE, F.I.D.C.; RIBELA, M.T.C.P.; UEDA, E.K.M. PROCESSO MICROBIOLÓGICO PARA OBTENÇÃO DE PLASMÍDEOS BACTERIANOS (VETORES OU CASSETES DE EXPRESSÃO) UTILIZANDO VETOR ABERTO COM PROMOTOR TERMO-SENSÍVEL DERIVADO DO FAGO LAMBDA E SUA APLICAÇÃO NA OBTENÇÃO DE ALTOS NÍVEIS DE SECREÇÃO DE PROTEÍNAS NO ESPAÇO PERIPLÁSMICO OU NO CITOPLASMA DE BACTÉRIAS Comissão Nacional de Energia Nuclear (BR/RJ) / Hormogen Biotecnologia Importação e Exportação Ltda (BR/SP), PI0406443-7, 04/11/2004. Extrapituitary prolactin: distribution, regulation, functions, and clinical aspects. Endocr Rev, v. 17, n. 6, p. 639-669, 1996.

BERNICHTEIN, S.; KAYSER, C.; DILLNER, K.; MOULIN, S.; KOPCHICK, J.J.; MARTIAL, J.A.; NORSTEDT, G.; ISAKSSON, O.; KELLY, P.A.; GOFFIN, V. Development of pure prolactin receptor antagonists. J Biol Chem, v. 278, n. 38, p. 35988-35999, 2003.

BERNICHTEIN, S.; TOURAINE, P.; GOFFIN, V. New concepts in prolactin biology. J Endocrinol, v. 206, n. 1, p. 1-11, 2010.

7 BRELJE, T.C.; BHAGROO, N.V.; STOUT, L.E.; SORENSON, R.L. Beneficial effects of lipids and prolactin on insulin secretion and beta-cell proliferation: a role for lipids in the adaptation of islets to pregnancy. $\boldsymbol{J}$ Endocrinol, v. 197, n. 2, p. 265-276, 2008. 
8 BROOKS, C.L.; KIM, B.G.; APHALE, P.; KLEEMAN, B.E.; JOHNSON, G.C. Phosphorylated variant of bovine prolactin. Mol Cell Endocrinol, v. 71, n. 2, p. 117-123, 1990.

9 CHEN, N.Y.; HOLLE, L.; LI, W.; PEIRCE, S.K.; BECK, M.T.; CHEN, W.Y. In vivo studies of the anti-tumor effects of a human prolactin antagonist, hPRL-G129R. Int J Oncol, v. 20, n. 4, p. 813-818, 2002.

10 CHEN, T.J.; KUO, C.B.; TSAI, K.F.; LIU, J.W.; CHEN, D.Y.; WALKER, A.M. Development of recombinant human prolactin receptor antagonists by molecular mimicry of the phosphorylated hormone. Endocrinology, v. 139, n. 2, p. 609-616, 1998.

11 CHUANG, E.; MOLITCH, M.E. Prolactin and autoimmune diseases in humans. Acta Biomed, v. 78 Suppl 1, n., p. 255-261, 2007.

CHURA-CHAMBI, R.M.; GENOVA, L.A.; AFFONSO, R.; MORGANTI, L. Refolding of endostatin from inclusion bodies using high hydrostatic pressure. Anal Biochem, v. 379, n. 1, p. 32-39, 2008.

CLAPP, C.; MARTIAL, J.A.; GUZMAN, R.C.; RENTIER-DELURE, F.; WEINER, R.I. The 16-kilodalton N-terminal fragment of human prolactin is a potent inhibitor of angiogenesis. Endocrinology, v. 133, n. 3, p. 12921299, 1993.

14 CROSIGNANI, P.G. Management of hyperprolactinemia in infertility. $\boldsymbol{J}$ Reprod Med, v. 44, n. 12 Suppl, p. 1116-1120, 1999.

DALMORA, S.; DE OLIVEIRA, J.E.; AFFONSO, R.; GIMBO, E.; RIBELA, M.T.; BARTOLINI, P. Analysis of recombinant human growth hormone directly in osmotic shock fluids. J Chromatogr A, v. 782, n. 2, p. 199-210, 1997.

16 DE BELLIS, A.; BIZZARRO, A.; PIVONELLO, R.; LOMBARDI, G.; BELlAStella, A. Prolactin and autoimmunity. Pituitary, v. 8, n. 1, p. 2530, 2005. 
17 DEPALATIS, L.; ALMGREN, C.M.; PATMASTAN, J.; TROYER, M.; WOODRICH, T.; BROOKS, C.L. Structure and function of a new class of human prolactin antagonists. Protein Expr Purif, v. 66, n. 2, p. 121-130, 2009.

18 DUENAS, Z.; TORNER, L.; CORBACHO, A.M.; OCHOA, A.; GUTIERREZOSPINA, G.; LOPEZ-BARRERA, F.; BARRIOS, F.A.; BERGER, P.; MARTINEZ DE LA ESCALERA, G.; CLAPP, C. Inhibition of rat corneal angiogenesis by $16-\mathrm{kDa}$ prolactin and by endogenous prolactin-like molecules. Invest Ophthalmol Vis Sci, v. 40, n. 11, p. 2498-2505, 1999.

19 ELBOURNE, K.B.; KEISLER, D.; MCMURRAY, R.W. Differential effects of estrogen and prolactin on autoimmune disease in the NZB/NZW F1 mouse model of systemic lupus erythematosus. Lupus, v. 7, n. 6, p. 420-427, 1998.

20 FERNANDEZ, I.; TOURAINE, P.; GOFFIN, V. Prolactin and Human Tumourogenesis. Journal of Neuroendocrinology, v. 22, n. 7, p. 771-777, 2010.

21 FERRARA, N.; CLAPP, C.; WEINER, R. The 16K fragment of prolactin specifically inhibits basal or fibroblast growth factor stimulated growth of capillary endothelial cells. Endocrinology, v. 129, n. 2, p. 896-900, 1991.

22 FREEMAN, M.E.; KANYICSKA, B.; LERANT, A.; NAGY, G. Prolactin: structure, function, and regulation of secretion. Physiol Rev, v. 80, n. 4, p. 1523-1631, 2000.

23 GERTLER, A. Recombinant analogues of prolactin, growth hormone, and placental lactogen: correlations between physical structure, binding characteristics, and activity. J Mammary Gland Biol Neoplasia, v. 2, n. 1, p. 69-80, 1997.

24 GLEZER, A.; SOARES, C.R.; VIEIRA, J.G.; GIANNELLA-NETO, D.; RIBELA, M.T.; GOFFIN, V.; BRONSTEIN, M.D. Human macroprolactin displays low biological activity via its homologous receptor in a new sensitive bioassay. J Clin Endocrinol Metab, v. 91, n. 3, p. 1048-1055, 2006. 
25 GOFFIN, V.; BERNICHTEIN, S.; KAYSER, C.; KELLY, P.A. Development of new prolactin analogs acting as pure prolactin receptor antagonists. Pituitary, v. 6, n. 2, p. 89-95, 2003.

26 GOFFIN, V.; BERNICHTEIN, S.; TOURAINE, P.; KELLY, P.A. Development and potential clinical uses of human prolactin receptor antagonists. Endocr Rev, v. 26, n. 3, p. 400-422, 2005.

27 GOFFIN, V.; BINART, N.; TOURAINE, P.; KELLY, P.A. Prolactin: the new biology of an old hormone. Annu Rev Physiol, v. 64, n., p. 47-67, 2002.

28 GRATTAN, D.R.; KOKAY, I.C. Prolactin: a pleiotropic neuroendocrine hormone. J Neuroendocrinol, v. 20, n. 6, p. 752-763, 2008.

29 GRIMALDI, C.M. Sex and systemic lupus erythematosus: the role of the sex hormones estrogen and prolactin on the regulation of autoreactive $B$ cells. Curr Opin Rheumatol, v. 18, n. 5, p. 456-461, 2006.

30 HANKINSON, S.E.; WILLETT, W.C.; MICHAUD, D.S.; MANSON, J.E.; COLDITZ, G.A.; LONGCOPE, C.; ROSNER, B.; SPEIZER, F.E. Plasma prolactin levels and subsequent risk of breast cancer in postmenopausal women. J Natl Cancer Inst, v. 91, n. 7, p. 629-634, 1999.

31 HANSEN, M.J.; OLSEN, J.G.; BERNICHTEIN, S.; O'SHEA, C.; SIGURSKJOLD, B.W.; GOFFIN, V.; KRAGELUND, B.B. Development of prolactin receptor antagonists with reduced $\mathrm{pH}$-dependence of receptor binding. J Mol Recognit, v., n., p., 2010.

32 HARIGAYA, T.; NAKAYAMA, K.; OHKUBO, H.; NAKANISHI, S.; SEO, H.; $\mathrm{HOSHINO}, \mathrm{K}$. Cloning and sequence analysis of cDNA for mouse prolactin. Biochim Biophys Acta, v. 868, n. 1, p. 30-38, 1986.

33 HATTORI, N.; IKEKUBO, K.; NAKAYA, Y.; KITAGAWA, K.; INAGAKI, C. Immunoglobulin $G$ subclasses and prolactin (PRL) isoforms in macroprolactinemia due to anti-PRL autoantibodies. J Clin Endocrinol Metab, v. 90, n. 5, p. 3036-3044, 2005. 
34 HO, T.W.; LEONG, F.S.; OLASO, C.H.; WALKER, A.M. Secretion of specific nonphosphorylated and phosphorylated rat prolactin isoforms at different stages of the estrous cycle. Neuroendocrinology, v. 58, n. 2, p. 160-165, 1993.

35 HORIGUCHI, K.; FUKUTA, S.; YOSHIDA, M.; KOSUGI, T.; NAITO, J.; ISHIDA, M.; HARIGAYA, T. Estrogen regulates the serum level of phosphorylated prolactin in mice. J Reprod Dev, v. 53, n. 4, p. 915-922, 2007a.

HORIGUCHI, K.; NAITO, J.; ISHIDA, M.; HARIGAYA, T. The effect of estrogen on phosphorylation of prolactin in the mouse pituitary gland. $\boldsymbol{J}$ Reprod Dev, v. 53, n. 3, p. 515-523, 2007b.

37 HWANG, P.; GUYDA, H.; FRIESEN, H. A radioimmunoassay for human prolactin. Proc Natl Acad Sci U S A, v. 68, n. 8, p. 1902-1906, 1971.

JACOBI, A.M.; ROHDE, W.; VENTZ, M.; RIEMEKASTEN, G.; BURMESTER, G.R.; HIEPE, F. Enhanced serum prolactin (PRL) in patients with systemic lupus erythematosus: $\mathrm{PRL}$ levels are related to the disease activity. Lupus, v. 10, n. 8, p. 554-561, 2001.

39 JENSEN, E.B.; CARLSEN, S. Production of recombinant human growth hormone in Escherichia coli: expression of different precursors and physiological effects of glucose, acetate, and salts. Biotechnol Bioeng, v. 36 , n. 1, p. 1-11, 1990.

40 KAUFMAN, R.J.; DAVIES, M.V.; WASLEY, L.C.; MICHNICK, D. Improved vectors for stable expression of foreign genes in mammalian cells by use of the untranslated leader sequence from EMC virus. Nucleic Acids Res, v. 19, n. 16, p. 4485-4490, 1991.

41 KIM, B.G.; BROOKS, C.L. Isolation and characterization of phosphorylated bovine prolactin. Biochem J, v. 296 ( Pt 1), n., p. 41-47, 1993.

42 KOHMOTO, K.; TSUNASAWA, S.; SAKIYAMA, F. Complete amino acid sequence of mouse prolactin. Eur $\boldsymbol{J}$ Biochem, v. 138, n. 2, p. 227-237, 1984. 
43 KOSHLAND, D.; BOTSTEIN, D. Secretion of beta-lactamase requires the carboxy end of the protein. Cell, v. 20, n. 3, p. 749-760, 1980.

44 KROWN, K.A.; WANG, Y.F.; HO, T.W.; KELLY, P.A.; WALKER, A.M. Prolactin isoform 2 as an autocrine growth factor for $\mathrm{GH} 3$ cells. Endocrinology, v. 131, n. 2, p. 595-602, 1992.

45 LABRIOLA, L.; MONTOR, W.R.; KROGH, K.; LOJUDICE, F.H.; GENZINI, T.; GOLDBERG, A.C.; ELIASCHEWITZ, F.G.; SOGAYAR, M.C. Beneficial effects of prolactin and laminin on human pancreatic islet-cell cultures. Mol Cell Endocrinol, v. 263, n. 1-2, p. 120-133, 2007.

46 LAEMMLI, U.K. Cleavage of structural proteins during the assembly of the head of bacteriophage T4. Nature, v. 227, n. 5259, p. 680-685, 1970.

47 LEWIS, U.J.; SINGH, R.N.; SEAVEY, B.K. Human prolactin: isolation and some properties. Biochem Biophys Res Commun, v. 44, n. 5, p. 11691176, 1971.

48 LLOVERA, M.; PICHARD, C.; BERNICHTEIN, S.; JEAY, S.; TOURAINE, P.; KELLY, P.A.; GOFFIN, V. Human prolactin (hPRL) antagonists inhibit hPRL-activated signaling pathways involved in breast cancer cell proliferation. Oncogene, v. 19, n. 41, p. 4695-4705, 2000.

49 MAKRIDES, S.C. Strategies for achieving high-level expression of genes in Escherichia coli. Microbiol Rev, v. 60, n. 3, p. 512-538, 1996.

50 MANIATIS, T.; FRITSCH, E.F.; SAMBROOK, J. Molecular cloning: a laboratory manual.Tradução de Nova lorque: Cold Spring Harbor Laboratory Press. 1989

51 MCMURRAY, R.; KEISLER, D.; IZUI, S.; WALKER, S.E. Hyperprolactinemia in male NZB/NZW (B/W) F1 mice: accelerated autoimmune disease with normal circulating testosterone. Clin Immunol Immunopathol, v. 71, n. 3, p. 338-343, 1994. 
52 NIELSEN, J.H. Effects of growth hormone, prolactin, and placental lactogen on insulin content and release, and deoxyribonucleic acid synthesis in cultured pancreatic islets. Endocrinology, v. 110, n. 2, p. 600-606, 1982.

53 OETTING, W.S.; TUAZON, P.T.; TRAUGH, J.A.; WALKER, A.M. Phosphorylation of prolactin. $\boldsymbol{J}$ Biol Chem, v. 261, n. 4, p. 1649-1652, 1986.

54 PERONI, C.N.; SOARES, C.R.; GIMBO, E.; MORGANTI, L.; RIBELA, M.T.; BARTOLINI, $P$. High-level expression of human thyroid-stimulating hormone in Chinese hamster ovary cells by co-transfection of dicistronic expression vectors followed by a dual-marker amplification strategy. Biotechnol Appl Biochem, v. 35, n. Pt 1, p. 19-26, 2002.

55 RAFFERTY, B.; RIGSBY, P.; GAINES-DAS, R.E. Draft Report of an International Collaborative Study of the proposed WHO Reference Reagents for rDNA-derived Prolactin and its Glycosylated and nonglycosylated components. WHO. Genova. 2001

56 RIBELA, M.T.; GOUT, P.W.; BARTOLINI, P. Synthesis and chromatographic purification of recombinant human pituitary hormones. $\boldsymbol{J}$ Chromatogr B Analyt Technol Biomed Life Sci, v. 790, n. 1-2, p. 285316, 2003.

57 RODRIGUES GOULART, H.; ARTHUSO, F.D.; CAPONE, M.V.N.; DE OLIVEIRA, T.L.; BARTOLINI, P.; SOARES, C.R.J. Enhancement of Human Prolactin Synthesis by Sodium Butyrate Addition to Serum-Free CHO Cell Culture. Journal of Biomedicine and Biotechnology, v., n., p. -, 2010.

58 SCHROEDER, M.D.; BROCKMAN, J.L.; WALKER, A.M.; SCHULER, L.A. Inhibition of prolactin (PRL)-induced proliferative signals in breast cancer cells by a molecular mimic of phosphorylated PRL, S179D-PRL. Endocrinology, v. 144, n. 12, p. 5300-5307, 2003.

SCHROEDER, M.D.; SYMOWICZ, J.; SCHULER, L.A. PRL modulates cell cycle regulators in mammary tumor epithelial cells. Mol Endocrinol, v. 16, n. 1, p. 45-57, 2002.

60 SINHA, Y.N. Structural variants of prolactin: occurrence and physiological significance. Endocr Rev, v. 16, n. 3, p. 354-369, 1995. 
61 SINHA, Y.N.; OTT, K.; VANDERLAAN, W.P. Detection of multiple PRL- and $\mathrm{GH}$-like proteins in human pituitary by Western blot analysis. $\mathbf{A m} \boldsymbol{J} \mathbf{M e d}$ Sci, v. 294, n. 1, p. 15-25, 1987.

62 SOARES, C.R.; GLEZER, A.; OKAZAKI, K.; UEDA, E.K.; HELLER, S.R.; WALKER, A.M.; GOFFIN, V.; BARTOLINI, P. Physico-chemical and biological characterizations of two human prolactin analogs exhibiting controversial bioactivity, synthesized in Chinese hamster ovary $(\mathrm{CHO})$ cells. Protein Expr Purif, v. 48, n. 2, p. 182-194, 2006.

SOARES, C.R.; GOMIDE, F.I.; UEDA, E.K.; BARTOLINI, P. Periplasmic expression of human growth hormone via plasmid vectors containing the lambdaPL promoter: use of HPLC for product quantification. Protein Eng, v. 16, n. 12, p. 1131-1138, 2003.

64 SOARES, C.R.; MORGANTI, L.; MILOUX, B.; LUPKER, J.H.; FERRARA, P.; BARTOLINI, P. High-level synthesis of human prolactin in ChineseHamster ovary cells. Biotechnol Appl Biochem, v. 32 ( Pt 2), n., p. 127135, 2000.

65 SOARES, C.R.; UEDA, E.K.; OLIVEIRA, T.L.; GOMIDE, F.I.; HELLER, S.R.; BARTOLINI, P. Distinct human prolactin (hPRL) and growth hormone (hGH) behavior under bacteriophage lambda $\mathrm{PL}$ promoter control: temperature plays a major role in protein yields. J Biotechnol, v. 133, n. 1, p. 27-35, 2008.

STATTIN, P.; RINALDI, S.; STENMAN, U.H.; RIBOLI, E.; HALLMANS, G.; BERGH, A.; KAAKS, R. Plasma prolactin and prostate cancer risk: A prospective study. Int J Cancer, v. 92, n. 3, p. 463-465, 2001.

67 TALLET, E.; ROUET, V.; JOMAIN, J.B.; KELLY, P.A.; BERNICHTEIN, S.; GOFFIN, V. Rational design of competitive prolactin/growth hormone receptor antagonists. J Mammary Gland Biol Neoplasia, v. 13, n. 1, p. 105-117, 2008.

TANAKA, T.; SHIU, R.P.; GOUT, P.W.; BEER, C.T.; NOBLE, R.L.; FRIESEN, H.G. A new sensitive and specific bioassay for lactogenic hormones: measurement of prolactin and growth hormone in human serum. J Clin Endocrinol Metab, v. 51, n. 5, p. 1058-1063, 1980. 
69 TERASAKI, Y.; YAHIRO, K.; PACHECO-RODRIGUEZ, G.; STEAGALL, W.K.; STYLIANOU, M.P.; EVANS, J.F.; WALKER, A.M.; MOSS, J. Effects of prolactin on TSC2-null Eker rat cells and in pulmonary lymphangioleiomyomatosis. Am J Respir Crit Care Med, v. 182, n. 4, p. 531-539, 2010.

70 TWOROGER, S.S.; ELIASSEN, A.H.; ROSNER, B.; SLUSS, P.; HANKINSON, S.E. Plasma prolactin concentrations and risk of postmenopausal breast cancer. Cancer Res, v. 64, n. 18, p. 6814-6819, 2004.

71 TWOROGER, S.S.; HANKINSON, S.E. Prolactin and breast cancer risk. Cancer Lett, v. 243, n. 2, p. 160-169, 2006.

72 TWOROGER, S.S.; HANKINSON, S.E. Prolactin and breast cancer etiology: an epidemiologic perspective. J Mammary Gland Biol Neoplasia, v. 13, n. 1, p. 41-53, 2008.

73 TWOROGER, S.S.; SLUSS, P.; HANKINSON, S.E. Association between plasma prolactin concentrations and risk of breast cancer among predominately premenopausal women. Cancer Res, v. 66, n. 4, p. 24762482, 2006.

74 UEDA, E.; OZERDEM, U.; CHEN, Y.H.; YAO, M.; HUANG, K.T.; SUN, H.; MARTINS-GREEN, M.; BARTOLINI, P.; WALKER, A.M. A molecular mimic demonstrates that phosphorylated human prolactin is a potent antiangiogenic hormone. Endocr Relat Cancer, v. 13, n. 1, p. 95-111, 2006.

75 UEDA, E.K.; LO, H.L.; BARTOLINI, P.; WALKER, A.M. S179D prolactin primarily uses the extrinsic pathway and mitogen-activated protein kinase signaling to induce apoptosis in human endothelial cells. Endocrinology, v. 147, n. 10, p. 4627-4637, 2006.

76 UEDA, E.K.; SOARES, C.R.; BARTOLINI, P.; DEGUZMAN, A.; LORENSON, M.Y.; WALKER, A.M. A molecular mimic of phosphorylated prolactin (S179D PRL) secreted by eukaryotic cells has a conformation with an increased positive surface charge compared to that of unmodified prolactin. Biochemistry, v. 48, n. 29, p. 6887-6897, 2009. 
77 UTAMA, F.E.; LEBARON, M.J.; NEILSON, L.M.; SULTAN, A.S.; PARLOW, A.F.; WAGNER, K.U.; RUI, H. Human prolactin receptors are insensitive to mouse prolactin: implications for xenotransplant modeling of human breast cancer in mice. J Endocrinol, v. 188, n. 3, p. 589-601, 2006.

78 UTAMA, F.E.; TRAN, T.H.; RYDER, A.; LEBARON, M.J.; PARLOW, A.F.; $\mathrm{RUI}, \mathrm{H}$. Insensitivity of human prolactin receptors to nonhuman prolactins: relevance for experimental modeling of prolactin receptor-expressing human cells. Endocrinology, v. 150, n. 4, p. 1782-1790, 2009.

79 WALKER, A.M. Phosphorylated and nonphosphorylated Prolactin isoforms. Trends Endocrinol Metab, v. 5, n. 5, p. 195-200, 1994.

WALKER, A.M. Unmodified and phosphorylated prolactin and gamma delta T cell development and function. Lupus, v. 10, n. 10, p. 735-741, 2001.

81 WALKER, A.M. Therapeutic potential of S179D prolactin--from prostate cancer to angioproliferative disorders: the first selective prolactin receptor modulator. Expert Opin Investig Drugs, v. 15, n. 10, p. 1257-1267, 2006.

WALKER, A.M. S179D prolactin: antagonistic agony! Mol Cell Endocrinol, v. 276, n. 1-2, p. 1-9, 2007.

83 WALKER, A.M.; MONTGOMERY, D.W.; SARAIYA, S.; HO, T.W.; GAREWAL, H.S.; WILSON, J.; LORAND, L. Prolactin-immunoglobulin G complexes from human serum act as costimulatory ligands causing proliferation of malignant B lymphocytes. Proc Natl Acad Sci U S A, v. 92, n. 8, p. 3278-3282, 1995.

84 WALKER, S.E. Bromocriptine treatment of systemic lupus erythematosus. Lupus, v. 10, n. 10, p. 762-768, 2001a.

85 WALKER, S.E. Treatment of systemic lupus erythematosus with bromocriptine. Lupus, v. 10, n. 3, p. 197-202, 2001b.

86 WALKER, S.E.; JACOBSON, J.D. Roles of prolactin and gonadotropinreleasing hormone in rheumatic diseases. Rheum Dis Clin North Am, v. 26, n. 4, p. 713-736, 2000. 
87 WALKER, S.E.; KEISLER, D.; KOMATIREDDY, G.R.; MCMURRAY, R.W. The effects of prolactin in animal models of SLE. Scand $\boldsymbol{J}$ Rheumatol Suppl, v. 107, n., p. 31-32, 1998.

88 WALKER, S.E.; YANG, L.; KUO, C.B.; M., W.A. A pilot study suggests that prolactin shortens, and a prolactin receptor antagonist lengthens, the life span of NZB/NZW mice with spontaneous lupus erythematosus. Endocrine Society Annual Meeting. San Diego - EUA. 12 15 junho 1999, 1999. P2-171 p.

89 WANG, Y.F.; LIU, J.W.; MAMIDI, M.; WALKER, A.M. Identification of the major site of rat prolactin phosphorylation as serine 177. $\boldsymbol{J}$ Biol Chem, v. 271, n. 5, p. 2462-2469, 1996.

90 WANG, Y.F.; WALKER, A.M. Dephosphorylation of standard prolactin produces a more biologically active molecule: evidence for antagonism between nonphosphorylated and phosphorylated prolactin in the stimulation of Nb2 cell proliferation. Endocrinology, v. 133, n. 5, p. 2156-2160, 1993.

91 WATAHIKI, M.; YAMAMOTO, M.; YAMAKAWA, M.; TANAKA, M.; NAKASHIMA, K. Conserved and unique amino acid residues in the domains of the growth hormones. Flounder growth hormone deduced from the cDNA sequence has the minimal size in the growth hormone prolactin gene family. J Biol Chem, v. 264, n. 1, p. 312-316, 1989.

92 WU, W.; CHEN, Y.H.; UEDA, E.; TAN, D.; BARTOLINI, P.; WALKER, A.M. Different forms of prolactin have opposing effects on the expression of cell cycle regulatory proteins in differentiated mammary epithelial cells. Oncol Res, v. 16, n. 2, p. 75-84, 2006.

93 WU, W.; COSS, D.; LORENSON, M.Y.; KUO, C.B.; XU, X.; WALKER, A.M. Different biological effects of unmodified prolactin and a molecular mimic of phosphorylated prolactin involve different signaling pathways. Biochemistry, v. 42, n. 24, p. 7561-7570, 2003.

94 XIE, W.J.; HE, Y.; HUO, D.; HUANG, Y.F.; WU, W. A mimic of phosphorylated prolactin inhibits human breast cancer cell proliferation via upregulation of p21 waf1. Medical Oncology, v. 27, n. 4, p. 1340-1345, 2010. 
95 XU, X.; KREYE, E.; KUO, C.B.; WALKER, A.M. A molecular mimic of phosphorylated prolactin markedly reduced tumor incidence and size when DU145 human prostate cancer cells were grown in nude mice. Cancer Res, v. 61, n. 16, p. 6098-6104, 2001.

96 YAMAMOTO, M.; HARIGAYA, T.; ICHIKAWA, T.; HOSHINO, K.; NAKASHIMA, K. Recombinant mouse prolactin: expression in Escherichia coli, purification and biological activity. J Mol Endocrinol, v. 8, n. 2, p. 165172, 1992. 